\title{
Archival research on integrated reporting: a systematic review of main drivers and the impact of integrated reporting on firm value
}

\author{
Patrick Velte ${ }^{1}$ (1)
}

Accepted: 3 May 2021 / Published online: 25 May 2021

(C) The Author(s) 2021

\begin{abstract}
Integrated reporting (IR) represents an innovative approach to business reporting especially by Public Interest Entities (PIEs). In addition to financial capital, the integrated report includes material information about manufactured, intellectual, human, social and relational, and natural capitals. Although there has been a steady growth in empirical IR research, there is - as yet-no literature review on the business case for IR. Thus, the purpose of this study is to convey a detailed understanding of the governance-, (non) financial performance-, and reporting-related determinants of IR and its contribution to firm value in line with the business case argument. To do so, we selected 85 quantitative peer-reviewed archival studies on that topic. We have then differentiated said studies between those that focus on IR adoption versus those that focus on IR quality, with a legitimacy- and stakeholder-theory-based framework. This differentiation is crucial, to stress the challenges of greenwashing policies and information overload. Here, in contrast to former literature reviews on IR, we provide new insights into this emerging research topic and concentrate on archival IR research. We are also interested in recent moderator- and mediator analysis in archival IR research since the business case argument for IR may require a specific environment, in addition to the main variables we have included. We likewise give a detailed overview of included variables and proxies and compare their main statistical effects. Our literature review demonstrates that (1) board composition and (2) stakeholder pressure positively influence IR quality; whereas (3) (non) financial performance leads to increased IR adoption and quality. We also find that both IR adoption and IR quality are linked with positive consequences on firm valuation, as they lead to higher total performance measures. Last but not least, this analysis includes useful recommendations for future IR research.
\end{abstract}

Keywords Integrated reporting - Corporate governance $\cdot$ Financial performance Legitimacy theory $\cdot$ Stakeholder theory $\cdot$ Archival research

Patrick Velte

velte@leuphana.de

Extended author information available on the last page of the article 
JEL classifications M41 · M48 · Q56

\section{Introduction}

Since the last financial crisis in 2008/2009, classical financial reporting has been widely criticised by shareholders and other stakeholder groups. Financial reports cannot explain the rising value gap between the balanced equity and the firm value of Public Interest Entities (PIEs). As a reaction, stakeholders are demanding reporting on non-financial aspects of PIEs, such as environmental or social information (Kolk \& van Tulder, 2010; Seuring \& Mueller, 2008). Many PIEs have thus decided to implement stand-alone Corporate Social Responsibility (CSR) reports as a complement to traditional financial reports (e.g., balance sheets). The Global Reporting Initiative (GRI) Standards describe CSR reports as a "best practice" by international PIEs (KPMG 2017). Yet the usefulness of non-financial reporting for decisionmaking has been discussed critically, due to greenwashing policy and information overload (see Huang \& Watson, 2015). Financial and CSR information are usually not linked within business reporting. Thus, stakeholders' interest in connecting these elements - ideally within one (integrated) report-is often not realised.

In light of these challenges, the International Integrated Reporting Council (IIRC) published a first version of a principle-based framework concept for integrated reporting (IR) (IIRC, 2013). In line with an integrated thinking approach and a focus on the materiality principle, IR requires a clear link between financial, manufactured, intellectual, human, social and relationship and natural capitals (IIRC, 2013). Thus, IR focusses on two "classical" economic-related capital items (financial and manufactured capitals); two social dimensions (human, social and relationship capitals); intellectual capital; and one environmental dimension (natural capital). The integrated thinking approach assumes a clear connectivity among these six capitals (IIRC, 2013). The IIRC (2013) defines an integrated report as "concise information about how an organisation's strategy, governance, performance and prospects, in the context of its external environment, lead to the creation of value over the short, medium and long term."

Separate CSR reporting and IR are totally different concepts with regard both to their reporting structure and to their main target groups. CSR reports represent an information tool for all relevant stakeholders. Meanwhile, the IIRC stresses in its IR framework (IIRC, 2013) that IR should primarily address investors, since this can support top management to implement IR without being confronted with various conflicts of interests among other stakeholder groups. Yet IR is not useful just for shareholders; it can also be useful for other stakeholders (Eccles \& Krzus, 2015). We thus regard IR as a stakeholder tool in this analysis.

Internationally, IR adoption is still voluntary for all companies with the exception of South Africa. While IR has gained some relevance in business practice (KPMG 2017), many resources are needed to adopt it. IR is thus mainly restricted to capital market firms. The current international regulatory discussion on climate change reporting implies that IR may replace CSR reporting in the long run as climate risks should be integrated into risk management systems and financial reports (Eccles \& 
Krzus, 2019). In recent years, IR has gained great importance in empirical research. While some literature reviews have been conducted on IR (e.g., de Villiers et al., 2017b; Kannenberg \& Schreck, 2019; Velte \& Stawinoga, 2017a; Vitolla et al., 2019a), we still lack a systematic understanding of governance, reporting and performance as main determinants and of their consequences on firm value from an archival-based research methodology. In this literature review, we rely on the business case for IR and assume that a proper IR may lead to positive firm valuation by the capital market and other stakeholders (Schaltegger et al., 2019; Carroll and Shaban 2010). Greenwashing and information overload are not just crucial challenges in CSR reporting, but may also be related to IR. We are thus not only interested in the consequences of IR on firm value. We also analyse, whether specific monitoring tools (governance) or firm-related incentives ([non] financial reporting and performance) drive the management decision to implement IR and to ensure its high quality, in line with stakeholders' interests. Prior research designs and topics are heterogeneous and complex, stressing the ambiguity of the impact of both governance-related and financial determinants and consequences. The previous literature reviews also lack a clear separation amongst the different IR proxies in archival research. In our literature review, we make a clear distinction between IR adoption and IR quality as the two most important proxies in IR archival research. As IR adoption is mostly voluntary worldwide, it is questionable whether certain governance-, performance-, and reporting-related aspects may strengthen the management decision to implement IR or whether IR adoption will lead to improved firm value. Here, since we have preferred to integrate the challenges of greenwashing and information overload in our analysis, the choice of IR adoption is not adequate. Instead, IR quality is more useful as the main proxy. This is because companies' motivation to engage in greenwashing behaviour and information overload should be decreased by an increased quality of IR. In terms of our research methodology, archival research is the most important method in analysing the business case for IR. Since other research methods, such as interviews, are not comparable for our vote counting technique, we focus here on empirical-quantitative (archival) studies. Prior reviews have also lacked a focus on moderator and mediator analysis in IR research. Yet moderators and mediators may be crucial to our archival IR research, as there may be a need for additional firm-specific attributes to strengthen or weaken our business case argument. A significant impact of selective determinants on IR, and their consequences on firm value, may only be found through the recognition of other moderators or mediators. Thus, the reliability of the knowledge we uncover regarding the business case for IR will be complemented by our separate recognition of those aspects. To achieve these aims, we will evaluate 85 archival studies on IR in this paper. We have established three main research questions:

(1) Do governance, (non) financial performance and reporting drive IR adoption (quality)?

(2) Does IR adoption (quality) lead to increased firm valuation (total performance measures, stock liquidity, cost of capital, and expected future cash flows)?

(3) Which moderators and mediators contribute to archival IR research? 
Given the recent widespread interest in IR, scientists' and other experts' commentary on the current trends and deduction of the key research gaps within IR from an international viewpoint have become increasingly vital. To conduct a systematic literature review, we first scanned business ethics and sustainability, management, finance, and accounting journals_-stressing the interdisciplinary nature of archival IR research and the increased relevance of this topic and chosen research method. Our research results, illustrating the main determinants and consequences of IR, are also useful for practitioners; they can increase practitioners' motivation to adopt IR, along with discussing measures to increase its quality. The results of our analysis are also relevant for (inter)national standard setters, as they may develop further regulations on (non) financial reporting.

Our results suggest that determinants are divided into governance-, (non) financial reporting and performance variables-on the one hand-and consequences of IR on firm value on the other hand. More specifically, firm-related governance determinants are mainly linked with (1) board composition, (2) ownership structure, and (3) stakeholder pressure. Country-related governance determinants differ along with regimes, regarding (1) civil law, (2) degree of legal enforcement, (3) level of investor protection, and (4) cultural aspects.

In our review, we also integrate (non) financial performance and reporting as possible drivers of IR adoption (quality). The consequences of IR on firm value will be structured in (1) total performance measures (e.g., Tobin's Q); (2) stock liquidity (e.g., bid-ask-spread as inverse proxy); (3) cost of capital; and (4) expected future cash flows (e.g., analyst forecast accuracy). Our results indicate that board composition and stakeholder pressure, as subgroups of corporate governance, are significantly positively related with IR quality. (Non) financial performance also leads to increased IR adoption and quality. We also stress that both IR adoption and quality are connected with higher firm values, based on total performance measures. Overall, our literature review extends and complements the state of knowledge on archival IR research.

Our analysis is structured as follows. First, we present a theoretical foundation to deduct our main determinants and consequences on firm value (Sect. 2.), wherein we rely on IR adoption and IR quality as key IR proxies (2.1) along with legitimacy theory (2.2) and stakeholder theory (2.3). Next, we determine our IR research framework and introduce our research methods (Sect. 3). This paper focusses on the findings of our literature review (Sect. 4), wherein we differentiate between bibliometric and content analyses of our included studies (4.1), corporate governance determinants (4.2), country-related governance determinants (4.3), (non) financial performance and reporting (4.4), IR consequences on firm value (4.5), moderator and mediator analysis (4.6), and results (4.7). The review then considers the limitations of the existing research and makes a useful contribution for future research activities in this field (Sect. 5), based on the structure of determinants and consequences. Section 6 provides a conclusion to our analysis. 


\section{Theoretical foundation}

\subsection{IR adoption and IR quality}

We have stressed that IR and CSR reporting represent different concepts. In this literature review, only archival studies on IR, according to the IIRC framework (IIRC, 2013), are included, to ensure the comparability of research results. IR adoption is one of the most important IR proxies, since IR is still voluntary from an international perspective. One exception is South Africa, where about 500 firms listed on the Johannesburg Stock Exchange must prepare an integrated report according to the King III Code. Many countries' financial regimes have implemented mandatory full or partial CSR reporting since the financial crisis of 2008/2009; IR can fulfil those mandatory regulatory requirements for CSR reporting (e.g., within the European Union). While CSR reporting and IR are different concepts, CSR reporting is a basic requirement for future IR adoption. Thus, the quality of CSR reports may have a strong impact on IR quality. IR quality can usually be evaluated via a content analysis of the various integrated reports and scoring methods. In South Africa, the Big Four audit firm EY regularly grants awards on IR quality; this information is also useful for IR analyses (Wang et al., 2020). Along with IR adoption, IR assurance by an external party is also voluntary from an international perspective (Velte \& Stawinoga, 2017a). The goal of IR assurance is to increase IR quality and firm reputation, in line with stakeholders' interests. Companies can choose between different IR assurors (e.g. audit firms or strategic consultant firms) and different assurance levels (limited versus reasonable level).

Merely adopting IR is not enough; IR quality is essential. An increased heterogeneity of practical IR strategies can be noted, which reduces comparability among companies (Flower, 2015). While IR should overcome the risks of greenwashing and information overload, that are attributed to stand-alone CSR reports, there are many elements of IR adoption and quality that are still up to managers' discretion (Flower, 2015). IR may also be used for symbolic management activities, as opposed to upholding stakeholders' interests. For these reasons, IR quality is most useful as the key variable in our literature review-in comparison to IR adoption as a dummy variable. IR quantity may be also relevant for information needs. We do not focus on IR quantity proxies in our literature review since we assume a rather low validity of this proxy, in view of the following. As IR is linked to the materiality principle, it is a major challenge to prevent of the provision of boilerplate and solely qualitative information (Gerwanski et al., 2019). A special disclosure practice is not stated in the IIRC framework. In business practice, two different disclosure options are stated: first, there is the option of a "summary IR", wherein all related (non) financial reports still exist and the IR complements the other reports. The second option is that of a real integration of the former stand-alone financial and nonfinancial reports into "one report". Neither a too short nor a too long IR is useful for shareholders and other stakeholders. There seems to be an "optimal" length for an integrated report, rather than a minimum-maximum decision or a linear relationship. Prior research does not analyse this relationship, but assumes a linear link. The 
optimal length of an integrated report is connected with other firm-specific determinants, such as industry, size, and business model; it is not comparable between firms or specific time frames.

\subsection{Legitimacy theory}

\subsubsection{Governance, (non) financial performance and reporting as determinants of IR}

Prior empirical research on IR has included a variety of different theories (e.g., legitimacy theory, stakeholder (agency) theory, institutional theory, and resource dependency theory) (Velte \& Stawinoga, 2017a, b). Velte and Stawinoga (2017a, b) differentiate between research on the market-, organisational- and individual or group decision-making level; the authors state that legitimacy theory and stakeholder (agent) theory are the most important theories in archival IR research. In line with this, we explicitly rely on legitimacy theory as our main theory in this literature review. Legitimacy theory describes either a substantial or a symbolic use of IR by top managers. A symbolic use of IR is linked with greenwashing behaviour and information overload; this strategy should met with an increased scepticism among shareholders and other stakeholder groups. We use stakeholder theory as an additional theory, to stress that a successful business case for IR should be clearly linked to the information needs of stakeholders. The board of directors and stakeholders should put pressure on executives to increase their IR strategies. Governance mechanisms as monitoring tools and (non) financial incentives may also be helpful to put pressure on the management to increase their IR efforts.

Legitimacy theory assumes that firms have implicit social contracts with the society in which they operate. These social contracts (Shocker \& Sehti, 1973) should motivate top management to comply with a society's specific values, norms and boundaries by implementing adequate sustainability structures and processes (Dowling \& Pfeffer, 1975). Firm's long-term existence is linked to its ability to meet society's sustainability goals. If legitimacy gaps are noted, firms should be requested to adopt legitimating strategies (Fernando \& Lawrence, 2014). According to legitimacy theory, firms change their reporting strategy to enhance their decision usefulness in line with stakeholders' information needs. Classical financial reporting does not guarantee an appropriate information basis for stakeholders. Since traditional balance sheets, according to (international) accounting standards, do not provide the broadest and most relevant variety of non-financial aspects, real firm value and balanced equity usually diverge. Separate CSR reporting, as a complement to financial reporting, is a first step to reaching legitimacy. However, since the financial crisis of 2008/2009, there is an increased risk of greenwashing policy and information overload in CSR reporting (Mahoney et al., 2013). Stakeholders expect improved connectivity among a firm's various financial and non-financial capitals, e.g., social or intellectual capital The main goal of IR, according to the IIRC framework (IIRC, 2013), is a clear integrated thinking process and a holistic view of the firm in value creation. The risks of greenwashing and information overload can also be related to IR in view of disclosure practices or different materiality judgments. 
Governance structure, for example, board effectiveness, has a major impact on IR strategies (Velte \& Stawinoga, 2017a). Boards and other governing mechanisms should put pressure on top management to implement IR and to guarantee an appropriate IR quality. Strong governance mechanisms may reduce greenwashing policies and increase firm reputation, according to legitimacy theory. Here, we differentiate between firm-related governance (corporate governance) and country-related governance factors in line with prior literature on related research items (e.g., Velte et al., 2020). Firm-related determinants mainly represent corporate governance variables that should motivate top management to adopt IR and to increase its quality. These determinants should enhance firms' legitimacy toward stakeholders' demands around connecting financial and CSR reporting. The following subgroups can be found:

(1) Board composition (e.g., board diversity, board independence);

(2) Ownership structure (e.g. institutional ownership); and

(3) Stakeholder pressure (e.g. by employees, customers).

Powerful shareholders and stakeholders should motivate top management to adopt IR and to increase its quality; this contrasts with situations in which there are powerful and opportunistic top managers and low levels of stakeholder influence.

Country-related determinants are linked to public awareness of IR. Governments should also motivate firms to change their business (reporting) strategies towards IR. These regimes can be categorised into:

(1) existence of a civil law regime (with a stakeholder perspective), in comparison to a case law regime (with a focus on shareholders' demands);

(2) strength of legal enforcement (indicating the influence of shareholders and other stakeholder groups on firms' compliance);

(3) degree of shareholder rights (indicating the influence of shareholders on the board of directors and thus increased investor protection rules); and

(4) cultural aspects, mainly based on Hofstede (power distance, masculinity versus feminism, individualism versus collectivism, long term orientation, indulgence).

The promotion of a stakeholder environment should lead to higher levels of IR adoption and increased IR quality, in comparison with regimes focussing on shareholders and opportunistic management behaviour.

In line with governance as a monitoring tool, top managers may be influenced by certain firm-specific incentives. To successfully implement IR, a company must invest significant internal resources and engage in a clear change process that effects every business department. IR requires a great deal of time and financial resources. As a first step, classical financial reporting should be augmented by a stand-alone CSR report. If a firm has not yet implemented CSR reporting over the previous years, it doesn't make sense for said firms to immediately adopt IR. Learning effects within non-financial reports and the (non) financial performance of the firm should influence management decisions around IR (Gerwanski et al., 2019): 
(1) performance (both financial and CSR performance); and

(2) reporting (both financial and CSR reporting).

In summary and in line with legitimacy theory, we state that governance, (non) financial performance, and reporting variables will mainly influence a firm's IR adoption (quality) to gain legitimacy. Yet a firm's IR (adoption) may also be limited to symbolic CSR-related activities or to providing "boilerplate" information, according to legitimacy theory. IR can be used as a simple marketing tool to attract new shareholders and other stakeholders, without any clear change in the firm's management control system (Velte \& Stawinoga, 2017a). Governance-related monitoring and (non) financial incentives may be too low or ineffective to shift the reporting behaviour of top managers from the symbolic use of IR to its application as a substantial business strategy.

\subsubsection{IR-related consequences on firm value}

According to legitimacy theory and the business case argument for IR, the adoption (and quality) of IR should lead to improved firm reputation and trust from stakeholders (Dowling \& Pfeffer, 1975). A firm with a successful IR strategy may receive (non) financial benefits (e.g., increased cash flows, liquidity) and thus improve its firm value. Stakeholders may use IR to assess the quality of CSR management, and related firm risks. If stakeholders are convinced that the management strategy is effective - and if they expect a low probability of greenwashing policy and information overload - they tend to reward firms with a lower risk premium and thus increased firm value. As IR should decrease the value gap between balanced equity and firm value, the increased connectivity of the six capitals noted in the IIRC framework should be value relevant for the capital market (Obeng et al., 2020a). Thus, IR can increase the information basis for shareholders and other stakeholders and support these groups in their decision-making, along with guaranteeing the efficiency of the capital market. As we are interested in the consequences of IR adoption (quality) on firm value and we note a great variety of related proxies, we rely on Barth et al. (2017) to structure the key output variables. Barth et al. (2017) identify two channels (capital market and real effects) through which IR is linked with firm value. The capital market channel relates to increased information for capital providers, while the real effect channel relates to increased internal decision-making by the management. The authors disaggregate firm value into three main components: (stock) liquidity, cost of capital, and expected future cash flows (Barth et al., 2017). (Stock) liquidity and cost of capital are capital market effects. Expected future cash flows may relate to both capital market and real effects. Legitimacy theory assumes that the implementation of high-quality IR may increase liquidity and share prices and decrease the cost of capital due to a reduced investor risk premium (Barth et al., 2017). We thus make a distinction between the following proxies of firm value:

(1) total performance measures (e.g., Tobin's Q);

(2) liquidity (e.g., bid-ask-spreads as inverse measure); 
(3) cost of capital; and

(4) expected future cash flows (e.g., analyst forecast accuracy).

Improved firm valuation is realistic only, if shareholders and other stakeholders trust IR. If IR is used merely as a "symbolic" marketing tool and greenwashing and information overload are not restricted, the stock market may react with an inconclusive or even negative valuation of the firm.

As legitimacy theory may relate to either a symbolic or a substantial use of IR adoption (quality), we complement our theoretical foundation by applying stakeholder theory in the following section.

\subsection{Stakeholder theory}

Legitimacy theory and stakeholder theory can be classified as complementary theories, when it comes to explaining the informational interests of IR for shareholders and other stakeholder groups. Stakeholder theory assumes that top managers will prevent possible greenwashing behaviour. According to stakeholder theory (Freeman, 1984), a firm must fulfil the expectations of different stakeholder groups (Freeman et al., 2010). These demands are multiple and are also linked with conflicts of interest (Fernando \& Lawrence, 2014). To solve these problems, based on a successful stakeholder management system, firms must systematically identify the legitimate claims of heterogeneous stakeholder groups regarding their business strategies (Freeman, 1984). As we have noted, shareholders and stakeholders question the decision-usefulness of financial reporting and of stand-alone CSR reporting due to greenwashing and information overload (Mahoney et al., 2013). The disclosure of clearly connected financial and non-financial information in IR, per legitimacy theory, can lead to substantive change processes within a firm (Graßmann et al., 2019). But, as noted, IR can also be used as a marketing tool or as merely a "symbolic" action. A clear focus on stakeholder management systems, in line with stakeholder theory, will increase the probability of a substantive use of IR (Freeman et al., 2010). Stakeholder theory posits that the information disclosed in integrated reports should reflect stakeholders' interests and that firms should try to respond to the heterogeneous expectations of different stakeholder groups (Eccles \& Krzus, 2015). Effective IR procedures require appropriate governance systems. The recognition of board effectiveness, monitoring of shareholders, and stakeholder pressure reduces the risk of a symbolic use of IR. It also increases the probability of a substantive use of IR, as a medium for an integrated thinking approach (Graßmann et al., 2019). Country-specific governance factors should also influence management's willingness to implement IR and to increase its quality. A substantive IR strategy will also be significantly influenced by financial determinants, e.g., (non) financial performance and reporting experiences which are most relevant in the early phase of IR adoption. Stakeholder awareness is an extremely sensitive topic in firms with dynamic performance and reporting development (Freeman et al., 2010). Learning effects on (non) financial reporting and a stabile performance situation within a firm will promote IR 
adoption (Gerwanski et al., 2019). If stakeholders trust the management's IR strategy, then IR may also lead to higher firm value.

Overall, we assume that governance, (non) financial performance and reporting will promote a firm's decision to prepare IR and to increase the quality of IR. This is based on legitimacy theory, in combination with stakeholder theory. We further assume that IR adoption and IR quality will strengthen stakeholder trust and decrease conflicts of interest, leading to a positive impact on firm value. Thus, according to stakeholder theory, we neglect the risks of a symbolic use of IR for the implementation of our research framework in Sect. 3. We then compare this assumption with the empirical results in our literature review in Sect. 4.

\section{IR research framework and method}

Here, we focus on the approach to IR put forth by the IIRC, which developed the IR concept and published its first official IR framework in December 2013 (IIRC, 2013). The second edition of the IIRC framework with small modifications has been published in January 2021. The IIRC framework is principle-based, allowing significant room for managerial discretion in the preparation process of an IR. Principlebased reporting cannot prevent the risk of heterogeneity and limited comparability. The risks of information overload for stakeholders and greenwashing policies can be decreased via a detailed quantitative explanation of the value gap between balanced equity and firm value, as well as of the materiality principle, in line with stakeholders' interests.

In line with this understanding of IR, Fig. 1 gives an overview of our research framework. The goal of our literature review is to offer a detailed analysis of the

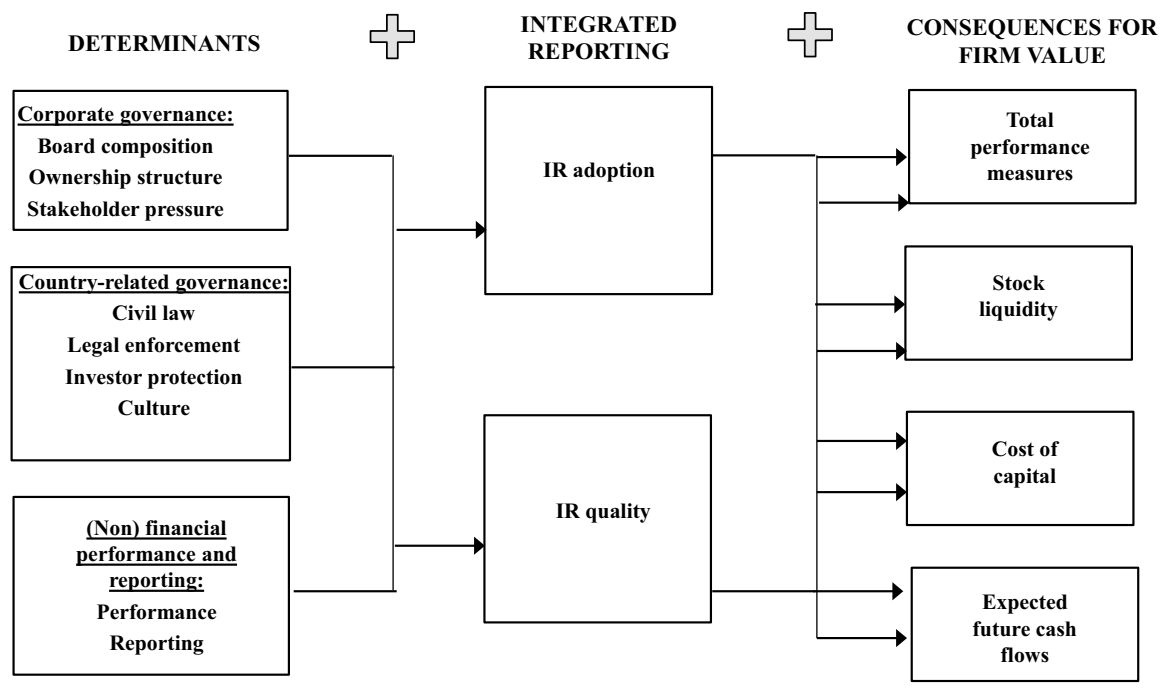

Fig. 1 Archival research on integrated reporting 
economic influences on, and relationships with IR. More specifically, we differentiate between IR adoption and IR quality in view of the heterogeneity of IR variables. Figure 1 stresses that our analysis is linked with:

(1) corporate governance-related determinants on IR;

(2) country-related governance factors of IR;

(3) (non) financial performance and reporting as determinants of IR; and

(4) consequences of IR on firm value.

Empirical research on IR is confronted with a heterogeneity of collected data, study designs, theoretical foundations, and analytical methods. This leads to studies that are largely disjointed. Literature reviews represent an innovative and relevant research method for scholars, practitioners, and regulators seeking to decrease research complexity (Torraco, 2005; Webster \& Watson, 2002). Our literature review is based on established processes (Denyer \& Tranfield, 2009). First, we extracted our research objective. Recent last years have seen an increased number of literature reviews, based on both conceptual and empirical IR results (e.g., de Villiers et al., 2017a). Yet no literature review has previously concentrated on the business case for IR and on archival research regarding the implementation of governance-related monitoring tools, (non) financial incentives and their implications for firm valuation. We see a major research gap on this topic, as regulators, practitioners, and researchers controversially debate which determinants might influence IR adoption and quality from an international perspective and whether IR leads to better economic consequences for firms. These questions are currently extremely important, as international standard setters discuss establishing mandatory IR for climate change policy, as one example (Eccles \& Krzus, 2019). Our key research questions are:

(1) Which governance-, (non) financial performance and reporting-related determinants are linked with IR adoption (quality)?

(2) Does IR adoption (quality) lead to increased firm value?

(3) Which moderators and mediators contribute to archival IR research?

In the context of these questions, we stress major research gaps and inconsistencies in prior archival IR research.

Second, we discussed the key theories and concepts in this research field, allowing us to select the specific terms to be used for our database search.

Third, relevant studies for our analysis were identified via a comparison of (inter) national databases (Web of Science, Google Scholar, the Social Science Network (SSRN), EBSCO and Science Direct). We used asterisks to search for related terms. The primary keywords were: "integrated reporting" in connection with "governance, "board composition", "ownership structure", "stakeholder pressure", "civil law", legal enforcement", "investor protection", "culture", "financial performance", "financial reporting", "corporate social responsibility", "corporate social 
responsibility reporting", "assurance", "capital costs", "firm value", "value relevance", "financial analysts" an related terms.

Fourth, we set the exclusion criteria. We did not focus on country of origin; thus both cross-country studies and national studies from selected regimes are included. In view of the short time frame in which archival IR research and the implementation of the IIRC framework have been in place, we did not restrict the time period. The earliest study included in our literature review was published in 2012. The latest publication date for included studies was December 2020. We included only quantitative empirical studies (archival based). This was because, first, these studies represent the most important research method to analyse the business case argument and our key research questions. Second, archival research on IR has increased in recent years and has been established as most dominant method, compared to qualitative designs (Velte \& Stawinoga, 2017a, b). Third, we wanted to ensure an adequate comparability of our included studies and to differentiate our literature review from prior reviews on IR that applied a mixed-methods design (e.g., de Villiers et al., $2017 \mathrm{a}, \mathrm{b})$. In our literature review, some researchers did gain their primary data via a content analysis of sustainability and corporate governance reports, interviews or surveys - per mixed-methods design - to deduct some variables of their regression models. Yet the archival data and regression models were focussed, in all included studies. To guarantee an appropriate level of quality, we recognised only articles published in English in peer-reviewed journals. In this context, it is vital to differentiate between archival IR and CSR reporting studies. We interpret CSR reporting-following the famous "triple bottom line"-implying a stand-alone report that covers a firm's social and environmental issues. CSR reporting is a complement to classical financial reporting, as a broad stakeholder tool. The goal of IR is different from that of stand-alone CSR reporting, since it combines six capitals (financial and CSR-related aspects are included) and concentrates on the materiality principle via an integrated thinking process. The risk of greenwashing policies and information overload should be thus lower than stand-alone CSR reports.

Fifth, as a precursory analysis of the studies, we scanned articles' titles to decide whether they should be included or excluded. We then read the theory and method sections of each study and eliminated those that did not fit our research question. We identified a total of 85 studies as final sample.

Sixth, the included studies were coded according to the selected (sub-) determinants and consequences and matched to our developed research framework. In line with vote-counting methodology (Light \& Smith, 1971), we noted the significant findings and their indicators.

\section{Findings of the literature review}

\subsection{Bibliometric and descriptive content analysis}

Table 1 provides an overview of the papers per publication year (Panel A), region (Panel B), journal (Panel C), content (Panel D) and IR variables (Panel E). Panel A stresses a steady increase in studies over the last few years and a rather young 
Table 1 Count of cited published papers
Panel A: by publication year

Total: 85

-2020: 28

-2019: 21

-2018: 10

-2017: 11

-2016: 7

-2015: 3

-2014: 2

-2013: 3

-2012: 1

Panel B: by region

Total: $85 \quad$ •Cross-country setting: 59

-South Africa: 17

-other regimes: 9

Panel C: by journal

Total: 85

-Business Ethics/Sustainability journals (41)

-Business Ethics: A European Review: 1

-Business Strategy and the Environment: 17

- Corporate Social Responsibility and Environmental Management: 9

-Journal of Business Ethics: 1

-Journal of Cleaner Production: 4

-Social Responsibility Journal: 3

-Sustainability: 4

-Sustainability Accounting, Management and Policy: 2

-Accounting and corporate finance journals (30):

- Abacus: 1

-Accounting, Organizations and Society: 1

-Asian Review of Accounting: 1

-Australian Accounting Review: 1

-European Accounting Review: 3

-International Journal of Accounting and Information

Management: 2

-International Journal of Managerial and Financial

Accounting: 2

-Journal of Accounting and Public Policy: 3

-Journal of Applied Corporate Finance: 2

-Journal of Financial Reporting and Accounting: 1

-Journal of Intellectual Capital: 3

-Journal of International Financial Management and

Accounting: 1

-Journal of Multinational Financial Management: 1

- Managerial Auditing Journal: 2

- Meditary Accountancy Research: 2

- Pacific-Basin Finance Journal: 1

- Research in International Business and Finance: 1

- Review of Quantitative Finance and Accounting: 1

- The British Accounting Review: 1

-Management/corporate governance journals (14)

- Academy of Strategic Management Journal: 1

-African Journal of Business Management: 1

- Cogent Business and Management: 1

-Corporate Board: 1

-Corporate Governance: 2

-Heliyon: 1

-International Business Review: 2

-International Journal of Business and Management: 2

-International Journal of Disclosure and Governance: 1

-International Journal of Law and Management: 1

-Problems and Perspectives in Management: 1 
Table 1 (continued)

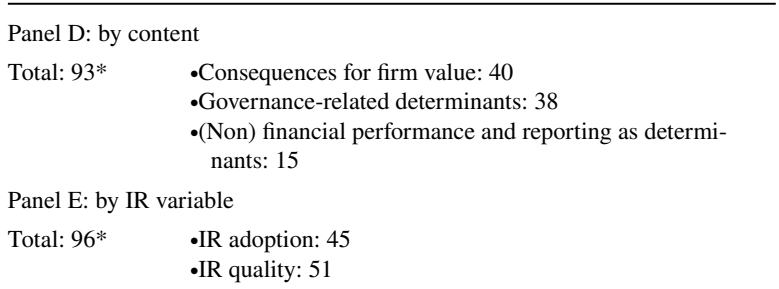

* Some studies include more than one dependent/independent variable, and content

research discipline (with the first study published in 2012). The year 2020 was our most important year of publication (28 studies). Most of the included studies focus on cross-country samples (59 studies) in contrast with the low relevance of conducting research on one specific country. Most of the international regimes do not request an integrated report for (public) firms so far. Yet there have been many discussions, from a regulatory perspective, as to whether a future regulation on IR is needed, for example, in the European Union. One key exception is South Africa (17 studies). As Since IR is mandatory in South Africa for PIEs, based upon a comply-or-explain mechanism from the King III Report on Corporate Governance, the country's listed firms are a common subject for archival IR studies. Mandatory and voluntary IR regimes lack comparability for the IR adoption variable in our literature review. In particular, we assume that capital market reactions will vary in mandatory versus voluntary IR regimes. Thus, we separately discuss the South African studies on IR adoption and compare them with study results on other regimes or cross-country studies. Panel $\mathrm{C}$ illustrates that heterogeneity of the journal publications, regarding discipline and quality. The best-known publication outlets are business ethics and sustainability journals (41 studies), for example, Business Strategy and the Environment (17 studies) and Corporate Social Responsibility and Environmental Management (9 studies). Yet classical accounting and finance journals (e.g., Journal of Accounting and Public Policy) and management and corporate governance journals are also relevant to this research topic. As seen in Panel D, studies exploring IR consequences on firm value (40 studies) and governance-related determinants (38 studies) are prominent, compared to other determinants. In recent years, archival research has included variables for both IR adoption (45 studies) and IR quality (51 studies). As previously noted, IR quality proxies are superior to IR adoption dummy variables, since top managers may implement IR intending to use it for greenwashing and to provide only boilerplate information. We are thus grateful for the increased number of IR quality studies over the past few years.

As prior determinants and consequences of IR in archival studies are rather heterogeneous and complex, we structure the main proxies in Table 2. Research on the governance-related determinants of IR can be classified as a highly complex topic. 


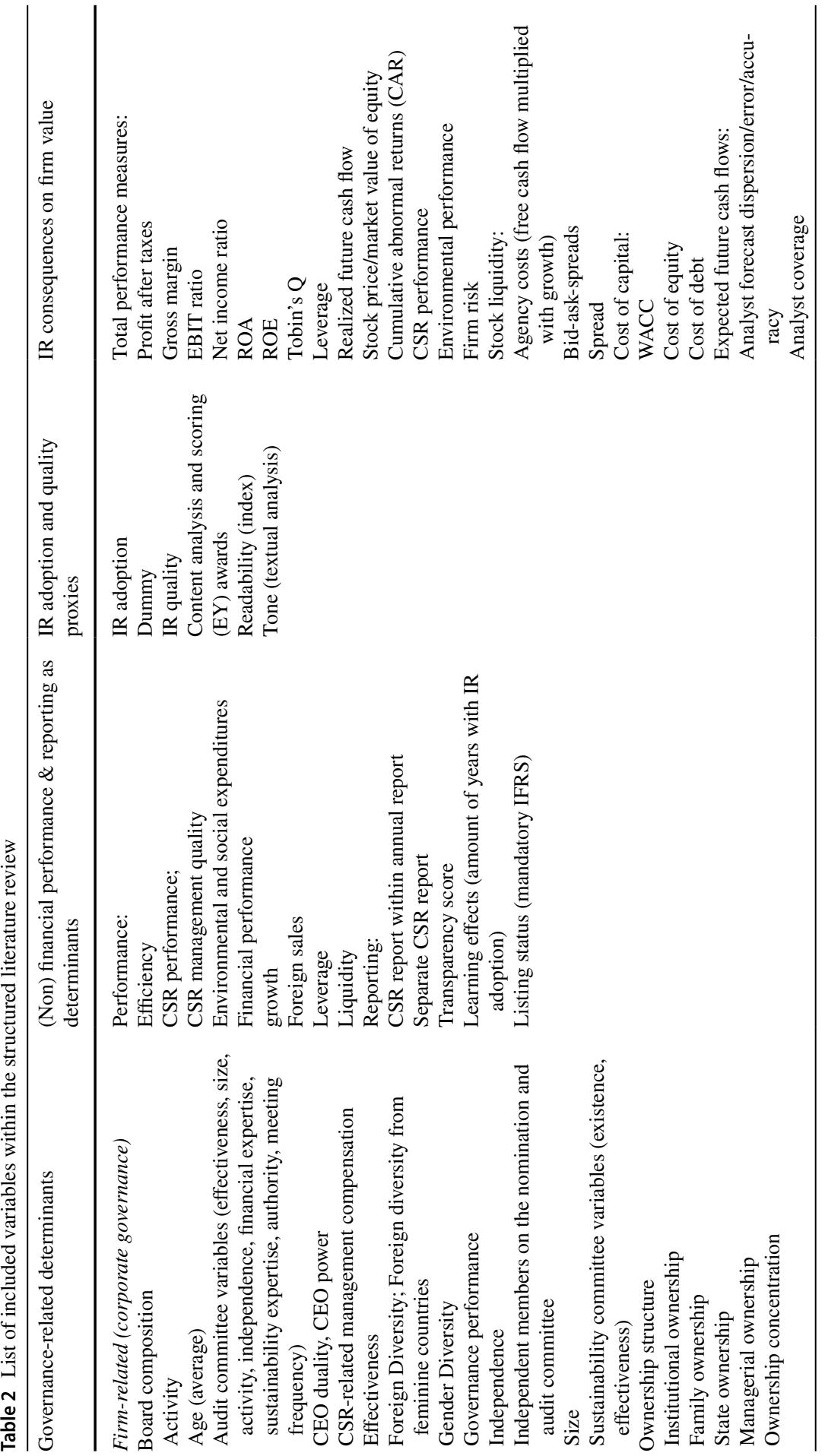




$$
D
$$




\subsection{Corporate governance-related determinants}

Corporate governance-related determinants are increasingly relevant, for both IR adoption and quality. Prior literature reviews and meta-analyses on the relationship between corporate governance and CSR (e.g. Guerrero-Villegas et al., 2018) stated that ownership and control should lead to increased IR activities. In line with prior literature, we differentiate between (1) board composition, (2) ownership structure, and (3) stakeholder pressure in our literature review. While IR quality is the most important measure, IR adoption has also been relevant in prior research designs. Two studies focus on Bloomberg's corporate governance index (Lai et al., 2016; Melloni et al., 2017). While Lai et al. (2016) found a positive impact of corporate governance performance on IR adoption, there are also studies that found insignificant influences on IR quality (Melloni et al., 2017). Governance performance may thus drive the likelihood of engaging in IR, without influencing IR quality. The following sections present the results of our review in terms of board composition, ownership structure and stakeholder pressure.

\subsubsection{Board composition}

The monitoring activities of a firm's board of directors should be aligned with stakeholders' interests (Ben-Amar and McIlkenny 2015). Strict monitoring by non-executives should be related with increased IR efforts, as stakeholders demand a clear link between a firm's various capitals and the interaction between financial and nonfinancial performance. A variety of board characteristics lead to board effectiveness and may have an impact on top management's decision to adopt IR and increase its quality (Gerwanski et al., 2019). Two studies in our literature review included a board effectiveness score; they found a positive influence on IR adoption (GarciaSanchez et al., 2019) and a positive influence on IR quality (based on a South African sample: Wang et al., 2020).

One of the most compelling corporate governance measures in IR research is board diversity, especially gender diversity (e.g., Rupley et al., 2012; McGuinness et al., 2017). Thus, prior studies have investigated the effect of overall board diversity (Vitolla et al., 2020a), gender diversity (e.g. Girella et al., 2019) and foreign diversity (e.g. Alfiero et al., 2018) on IR practices. According to Vitolla et al., (2020a, d), board diversity and IR quality are positively linked. Since female directors may enrich board decisions in part by representing diverse stakeholders' demands, skills, values and beliefs, Frias-Aceituno et al. (2013b) found a positive relationship between board gender diversity and IR adoption. However, Girella et al. (2019) and Garcia-Sanchez and Noguera-Gamez (2018) did not observe a significant link. According to Marrone (2020), Gerwanski et al. (2019), and Kilic and Kuzey (2018), gender diversity positively affects IR quality; yet Fasan and Mio (2017) found an opposite effect. The authors assume that problems in IR adoption may lead to employing higher board diversity as a signal to markets that, which, however, is not followed by successful strategies to increase IR quality. Foreign board diversity is another key diversity variable. Boards with at least three foreign members have been shown to lead to increased IR adoption (Alfiero et al., 2018), over those with 
fewer such members. According to Alfiero et al. (2018), if the majority of foreign board members comes from countries showing a higher femininity orientation, IR adoption is also increased. Yet Frias-Aceituno et al. (2013b) did not find any link between foreign board diversity and IR adoption.

Along with diversity, prior studies have also investigated the effect of board independence on IR practices (e.g., Fasan \& Mio, 2017; Stacchezzini et al., 2016). Vitolla et al. (2020a, d) found a positive relationship between board independence and IR quality. Stacchezzini et al. (2016) stated a negative association regarding to managerial discretion in the preparation of IR, as an inverse measure of board effectiveness. Other studies did not find any significant effects of board independence on either IR adoption (Frias-Aceituno et al., 2013b; Girella et al., 2019) or IR quality (Fasan \& Mio, 2017; Kilic \& Kuzey, 2018).

Board size and board activity are also relevant corporate governance variables found in the archival research. Some researchers assume that greater board size and meeting frequency lead to more discourse and thus to increased board effectiveness. Girella et al. (2019), Alfiero et al. (2018) and Frias-Aceituno et al. (2013b) showed that firms with larger boards are more likely to adopt IR. Meanwhile, Marrone (2020) and Vitolla et al. (2020a, d) found a positive impact of board size on IR quality. In contrast to this, some researchers have found an insignificant effect on both IR adoption (Garcia-Sanchez \& Noguera-Gamez, 2018) and IR quality (Kilic \& Kuzey, 2018). Fasan and Mio (2017) reported that board size even impairs IR quality. Next to board size, board activity has drawn less attraction in IR research to date. With the exception of the studies carried out by Vitolla et al. (2020a, d), which emphasis a positive impact on IR quality, other studies have found no link between board activity, IR adoption (Frias-Aceituno et al., 2013b), and IR quality (Fasan \& Mio, 2017). Marrone (2020) included board average age as a possible driver of IR quality and reported insignificant results.

Since the 2002 Sarbanes Oxley Act enacted in the US but with international relevance, research on board effectiveness has focused on audit committees and their monitoring role in corporate governance. The role of audit committees is to control a firm's IR process, managers, internal auditors, and external auditors (Klein 2002; Haji \& Anifowose, 2016). An effective audit committee should incentivise the top management to implement IR and to increase IR quality, in line with stakeholders' interests. In a South African setting, Haji and Anifowose (2016) and Wang et al. (2020) found that audit committee effectiveness increases IR quality. Audit committee financial expertise and sustainability expertise also increase IR quality in voluntary settings according to Velte (2018), as does the interaction between the two variables. Yet Haji and Anifowose (2016) found no link between the financial expertise of the audit committee and IR quality. The authors also investigated whether audit committee size, activity, independence, expertise and authority contribute to IR quality. Only audit committee activity and authority contribute to better IR quality (Haji \& Anifowose, 2016). Raimo et al. (2020a) also investigated voluntary IR settings; they reported a positive influence of audit committee size, independence and meeting frequency on IR quality, while financial expertise on the audit committee has no impact. Pavlopoulos et al. (2017) studied the impact of independent members on the nomination and audit committee and reported a positive effect on IR quality. 
Two recent studies in South African's mandatory IR setting have concentrated on sustainability committees as promoters of CSR strategies and IR in line with the increased stakeholder awareness of CSR strategies and related reporting. Haji and Anifowose (2016) and Wang et al. (2020) argue that a firm's sustainability committee has an essential role in supporting its audit committee's monitoring role in IR, and should thus lead to higher IR quality. There are indications that both the existence (Haji \& Anifowose, 2016) and the effectiveness (Wang et al., 2020) of sustainability committees increase IR quality.

Management compensation represents another key incentive alignment mechanism in corporate governance. Since the financial crisis of 2008-2009, stakeholders are demanding a clear integration of (non) financial aspects, such as climate change targets within variable top management compensation. Thus, CSR-related management compensation should lead to increased CSR awareness and openness among top management. This has been researched in a single South African study by Wang et al. (2020), who found an increased effect on IR quality.

Finally, behavioural corporate governance research assumes that individual characteristics of board members, especially of the Chief Executive Officer (CEO), may have an impact on IR strategies. Garcia-Sánchez et al. (2020) reported a negative impact of CEO power on IR adoption. Marrone (2020) found a negative relationship between $C E O$ duality and IR quality, as two inverse measures of board effectiveness.

\subsubsection{Ownership structure}

Next to board composition, the literature stresses a strong impact of ownership structure, as an external corporate governance mechanism, on IR activities (Raimo et al., 2020b). In contrast to private investors and their reduced resources, (sustainable) institutional investors may put pressure on the top management to implement IR and to reach a higher quality. Thus far, ownership variables have been included to a rather low degree. Blockholders imply both an increased information demand for IR and higher bargaining power. Thus, ownership concentration may be linked to increased IR efforts. Jensen and Berg (2012) proved this assumption with regard to IR adoption. Likewise, Vitolla et al. (2019a) have proven his assumption for voluntary IR regimes and Haji and Anifowose (2016) have done so regarding IR quality in South Africa. In contrast to this, Graßmann et al. (2019) and Raimo et al. (2020b) found a negative effect on IR quality, while Fuhrmann (2019) study found ownership concentration to have an insignificant impact on IR adoption. According to Serafeim (2015), IR firms are connected with more long-term investors. Raimo et al. (2020b) indicated a negative impact of managerial and state ownership on IR quality and a positive impact of institutional ownership. Gerwanski et al. (2019) investigated whether a corporation with a listing in the Dow Jones Sustainability Index (DJSI) is linked with IR qualityand found insignificant effects.

\subsubsection{Stakeholder pressure}

Stakeholder pressure becomes more and more important in recent years. Given such risks as information overload and greenwashing behaviour (Garcia-Sanchez et al., 
2019; Gerwanski et al., 2019), the decision usefulness of IR is a major goal of stakeholders. Stakeholders such as customers and suppliers put pressure on top management to ensure adequate IR quality. (Voluntary) external assurance, for example, by professional accountants, can mitigate conflicts of interest between management and stakeholders and can increase stakeholders' trust in IR (Simnett \& Huggins, 2015; Velte \& Stawinoga, 2017b). Some researchers include CSR assurance as an external corporate governance variable (e.g., Sierra-Garcia et al., 2015). Managers that engage a third party to assure their stand-alone CSR reports might likewise be willing to spend money on IR and to be more focused on the credibility of IR. While Sierra-Garcia et al. (2015) found a positive effect of CSR assurance on IR adoption, the choice of CSR assuror (audit firm) did not make a difference. Next to CSR assurance, IR assurance was included as a possible determinant of IR strategies. Maroun (2019), based on a South African sample, documented a positive impact of IR assurance on IR quality, as did Gerwanski et al. (2019). Yet Vaz et al. (2016) and RiveraArrubla et al. (2017) were unable to confirm this hypothesis. Ghani et al. (2018) and Rivera-Arrubla et al. (2017) proved that the appointment of a Big4 auditor for the financial audit (as an indicator for increased audit quality) has a positive influence on IR quality. Chouaibi and Hichri (2020) have documented that auditor industry specialisation and the existence of a code of ethics within an audit firm both positively influence IR quality, while Big Four audit firms and behavioural skills have no influence.

Stakeholder pressure is not just related to shareholders' demands for a credible business reporting, but also to the demands of other stakeholder groups (e.g., customers, employees). Kim et al. (2019)have stressed that employee pressure leads to increased IR adoption. Vitolla et al. (2019a) have also reported a positive effect of employee pressure, customer pressure and environmental protection organisations' pressure on IR quality.

\subsection{Country-specific governance determinants}

In the last section, we stressed the impact of corporate governance on IR adoption and IR quality. Most studies included in this literature review rely on an international IR sample, while country-specific governance factors have also been addressed. The literature assumes that country-specific governance factors may also have a huge impact on the management decision to conduct IR and to increase IR quality (Fuhrmann 2019). We differentiate between four main subgroups in our analysis: (1) presence of a civil (code) law, (2) degree of legal enforcement, (3) range of investor protection (shareholder rights), and (4) cultural aspects.

\subsubsection{Civil law}

A classical differentiation amongst each country's orientation can be made between common (case) or civil (code) law regimes (Vaz et al., 2016). Case law regimes are assumed to include stricter shareholder rights and to rely on investor protection, whereas civil (code) law regimes tend to focus on broader stakeholder topics. Case 
law regimes are linked with increased shareholder value, whereas code law regimes have a stricter connection to stakeholder value. Since IR may be classified as an explicit shareholder tool or as a broader stakeholder approach, there may be heterogeneous influences. Fuhrmann (2019), Garcia-Sanchez et al. (2019) and Frias-Aceituno et al. (2013a) have stated that firms operating in civil law regimes promote IR adoption. However, other studies have not found a relationship (Garcia-Sanchez \& Noguera-Gamez, 2018; Girella et al., 2019; Jensen \& Berg, 2012; Vaz et al., 2016). There are also heterogeneous results regarding IR quality. Both positive effects (Vitolla et al., 2020a, b, c, d) and insignificant impacts of civil law on IR quality have been occurred (Fasan \& Mio, 2017; Rivera-Arrubla et al., 2017).

\subsubsection{Legal enforcement}

The strength of legal enforcement has also been included in some cross-country studies on IR. The literature assumes that legal enforcement leads to higher managerial willingness to fulfil the information demands of their stakeholders, which in turn leads to IR adoption and better IR quality (e.g., Frias-Aceituno et al., 2013a; Garcia-Sanchez \& Noguera-Gamez, 2018). Garcia-Sanchez and Noguera-Gamez (2018) and Frias-Aceituno et al. (2013a) indicate that legal enforcement (i.e., the efficiency of the legal system and the index of law and order) drives IR adoption. Other researchers have included corruption perception: positive results are reported by Girella et al. (2019), while insignificant results are stated by Garcia-Sanchez et al. (2019).

\subsubsection{Investor protection}

The level of investor protection relies on a variety of elements, which can be measured, for example, via factorial analysis of an anti-self-dealing index, creditor rights index and market development. Prior research on IR adoption and investor protection found heterogeneous results. A positive link (Jensen \& Berg, 2012), negative relationships (Fuhrmann 2019) and insignificant results (Garcia-Sanchez \& Noguera-Gamez, 2018; Vaz et al., 2016) can all be reported.

\subsubsection{Culture}

Last but not least, Hofstede's cultural dimensions (collectivism, indulgence, long term orientation, feminism, power distance, and uncertainty avoidance) have been included in prior archival research on IR (e.g., Garcia-Sánchez et al., 2013; Vaz et al., 2016). The literature assumes that a country's culture affects not just individuals, but also corporations, and that it determines firms' IR strategy (Vaz et al., 2016). The cultural backdrop of a specific regime may promote or weaken top managers' motivation to strengthen their IR activities. Girella et al. (2019), Vaz et al. (2016) and Garcia-Sánchez et al. (2013) have stated that IR adoption is more likely in countries with a higher degree of collectivism, while Fuhrmann (2019) did not find any significant results. Collectivism also leads to increased IR quality (Vitolla et al., 2019b). Fuhrmann (2019) have stressed an insignificant effect of indulgence 
on IR adoption, whereas IR quality is even lower (Vitolla et al., 2019b). Girella et al. (2019) found long-term orientation and IR to be positively related, whereas some studies found no indication of this (based on IR adoption: Fuhrmann 2019; Garcia-Sánchez et al., 2013; based on IR quality: Vitolla et al., 2019b). Feminism also increases IR adoption (Fuhrmann 2019; Girella et al., 2019; Garcia-Sánchez et al., 2013) and IR quality (Vitolla et al., 2019b)—with the exception of Vaz et al.'s findings (2016). In contrast to this, power distance reduces both IR adoption-according to Fuhrmann (2019-and IR quality (Vitolla et al., 2019b). Garcia-Sánchez et al. (2013) found no any relationship between uncertainty avoidance and IR quality. Vitolla et al. (2019b) stressed a positive impact on IR quality, while Jensen and Berg (2012) noted increased IR adoption according to higher national CSR indexes.

\section{4 (Non) financial performance and reporting}

Along with governance-related determinants, prior research also recognises (non) financial determinants as possible management incentives for increased IR efforts. (Non) financial reporting and performance may be the basis for top management to start out on a firm's IR journey. In our review, we differentiate between (non) financial performance and reporting.

\subsubsection{Performance}

The majority of the studies included, on this topic analyse the impact of financial performance on IR. As IR is linked with increased resources within a firm it is assumed that financial performance and IR strategies are positively linked (e.g. Girella et al., 2019; Vitolla et al., 2020a). Top managers will be more motivated to increase their IR efforts when they achieve specific performance figures allowing them to signal their successful business model and their personal contribution to their stakeholders. A variety of heterogeneous financial performance measures have been used in prior research. Measures of financial performance can be accountingbased (e.g., Return on Assets [ROA]) or market-based (e.g., Tobin's Q). Some studies indicate a positive impact of financial performance on IR adoption, based on ROA (Girella et al., 2019; Frias-Aceituno 2014; Oshika \& Saka, 2017), market-tobook-ratio (Girella et al., 2019), gross margin, Earnings before Interest and Taxes (EBIT) ratio, net income ratio, and Return on Equity (ROE) (Oshika \& Saka, 2017). Fuhrmann (2019) has stated that firms with lower leverage are more likely to adopt IR. However, Lai et al. (2016) have reported a negative effect of ROA on IR implementation. Other researchers found no significant results regarding ROA (Fuhrmann, 2019), leverage (Girella et al., 2019; Lai et al., 2016), firm efficiency (Girella et al., 2019), and growth (Frias-Aceituno et al., 2014). Heterogeneous results are also found in the relationship between financial performance and IR quality. Vitolla et al. (2020a) and Graßmann et al. (2019) found a positive link between ROA and IR quality. There are also indications that tone bias (inverse IR quality) is found to be lowered by increased firm revenues (Roman et al., 2019). Other researchers found no significant relationships, based on Return on Invested Capital (ROIC) (Churet \& 
Eccles, 2014), leverage (Ghani et al., 2018), price volatility (Graßmann et al., 2019) or liquidity (Ghani et al., 2018). Vitolla et al., (2020a) and Graßmann et al. (2019) reported a positive impact of leverage as an inverse measure on IR quality. A negative relationship between foreign sales and IR quality has also been reported by Graßmann et al. (2019).

Since IR represents an integration of six different capital items, not just financial performance, but also CSR performance, as pre-financials, may be important drivers for IR. Top managers will be more willing to produce an integrated report, if their firms' CSR performance shows a positive development. This assumption will be primarily of importance for self-impression management. However, in comparison to financial performance, CSR performance is of lower relevance in prior research designs (e.g. Lai et al., 2016). Lai et al. (2016) found a positive impact of CSR performance on IR adoption, while Fuhrmann (2019)'s study found a positive significance on social performance as a subpillar of CSR. Maniora (2017) stated a positive relationship between CSR performance and IR implementation in comparison with non-CSR reporters and firms that included their CSR reporting in their annual reports. In a direct comparison with firms that prepare a stand-alone CSR report, CSR performance is lower amongst IR adopters. In view of IR quality, CSR performance (Churet \& Eccles, 2014; Graßmann et al 2019) is higher. However, Beretta et al. (2019) noted a higher degree of tone bias if CSR performance increases, leading to a negative relationship between CSR performance and IR quality.

\subsubsection{Reporting}

(Non) financial performance and reporting are interdisciplinary variables. Empirical research on (non) financial reporting and performance assumes that there can be a bidirectional relationship. Performance may influence the reporting behaviour of top management and vice versa (Velte et al., 2020). As IR includes a variety of information from different reports (e.g., financial-, CSR-, and governance reports), an adequate quality of (non) financial reporting may be a driver and an incentive for top managers to implement IR and increase its quality. In a direct comparison between studies on performance and reporting, we note that few studies address the impact of (non) financial reporting on IR. Wachira et al. (2019) included a transparency score and found a positive influence on IR adoption in South Africa. Gerwanski et al. (2019) stated that past experiences with IR (=learning effects) increase IR quality, while IR readability did not show a significant impact. Romero et al. (2019) found that stand-alone CSR reports were linked to increased IR quality, in contrast with CSR reports, within annual reports. Finally, prior studies found no significant results on earnings quality (Gerwanski et al., 2019; Pavlopoulos et al., 2019).

\subsection{IR-related consequences on firm value}

One of most intensive research topics in our literature review deals with the consequences of IR adoption (quality) on firm value. Researchers assume that both IR adoption and IR quality have a positive impact on firm valuation in the long run 
(Muttakin et al., 2020). There is much heterogeneity in prior studies, when it comes to approximate firm value. In this literature review, we rely on a structure by Barth et al. (2017) who differentiate between the following components of firm value: (1) liquidity (e.g., bid-ask-spread as inverse measure), (2) cost of capital, and (3) expected future cash flows (e.g., analyst forecasts and coverage). In line with these proxies, total performance measures (e.g., Tobin's Q) are also included in prior research to approximate firm value (Barth et al., 2017).

\subsubsection{Total performance measures}

In the last section, we mentioned the variety of total performance measures in archival research. Firm performance proxies may not just be an important determinant of IR strategies; they may also lead to better (non) financial performance, in terms of increased firm reputation among stakeholders (Cortesi \& Vena, 2019). Since aspects of CSR aspects may also have a main effect on firm value, some studies also include CSR performance along with financial performance. The results of the prior tend to be homogeneous and indicators have been found to support a positive (negative) relationship between IR strategies and performance. Akisik and Gal (2019) reported a positive link between IR adoption, stock price growth, ROE and ROA. Firm risk (Conway, 2019) and leverage (Lemma et al., 2019) are also lower alongside IR adoption in the mandatory South African setting; a positive effect on firm value is thus assumed. IR adoption also leads to improved CSR performance (Loprevite et al., 2018). Conway (2019), based on a South African setting, concluded that there was a negative relationship between IR adoption, IR quality, and financial performance, while there was a positive relationship between IR quality and CSR performance.

Along with accounting-based performance measures, value relevance studies have gained great importance when it comes to measuring market-based financial performance. Event studies and the modified Ohlson model have been often used in prior IR research. The Ohlson model is linked to stock prices or market values of equity, whereas event study designs focus on cumulative abnormal returns (CAR) (Cortesi \& Vena, 2019). Most studies included in our review rely on the Ohlson model based on market values of equity. A positive impact of IR adoption on the market value of equity has been documented, for both voluntary (Cortesi \& Vena, 2019) and mandatory IR regimes (Baboukardos \& Rimmel, 2016). Similar relationships occur for the value relevance of earnings in voluntary IR regimes (Loprevite et al., 2018) and for organisational capital in South Africa (Tlili et al., 2019). Wahl et al. (2020), Gal and Akisik (2020), Loprevite et al. (2019a, b) and Camodeca et al. (2018) did not state any significant relationship between IR adoption and the market value of equity (Tobin's Q), whereas Landau et al. (2020) reported a negative link.

Similar results occur for IR quality. Financial performance seems to be higher in both voluntary and mandatory IR settings, based on profit after taxes (Adegboyegun et al., 2020), ROA (Pavlopoulos et al., 2019), Tobin's Q [evidence in South Africa: Moloi \& Iredele, 2020, Barth et al., 2017; Lee \& Yeo, 2016; Dey, 2020 (Bangladesh); based on IR readability: Caglio et al. 2020], and lower firm risk (Conway, 2019). Other studies have stressed a positive impact of IR quality on the market value of equity (Pavlopoulos et al., 2019), and CAR (Pavlopoulos et al., 2019; 
Cosma et al., 2018). However, Gal and Akisik (2020), Loprevite et al. (2019a, b) and Camodeca et al. (2018) have found insignificant results in this regard. Caglio et al. (2020) reported no significant relationship between IR tone bias and Tobin's $\mathrm{Q}$ in a South African setting. The authors also found no significant link between IR readability, IR tone bias, and CSR performance. Omran et al. (2020) reported a positive impact of IR quality on environmental performance.

\subsubsection{Liquidity}

Some researchers do not rely on total financial performance proxies, but concentrate instead on the specific components of firm value for a more detailed analysis. (Stock) liquidity is one of these subgroups (Barth et al., 2017) and can be inversely measured by bid-ask-spreads. The literature states that bid-ask-spreads indicate the range of information asymmetry on capital markets (Barth et al., 2017). When information asymmetry is low, investors are more willing to grade a firm, which should be linked with lower bid-ask-spreads. Bid-ask-spreads, as an inverse measure of liquidity, are usually defined as the median of the difference between daily closing bid and ask prices divided by their midpoint (Barth et al., 2017). In this review, we recognise only research on IR quality in this regard, but not on IR adoption. Zuniga et al. (2020) and Barth et al. (2017) found a positive impact of IR quality on liquidity, in an South African context. Caglio et al. (2020) stated an insignificant link between IR quality (readability, tone bias) and bid-ask-spreads in South Africa. Similar results were reported by Sriani and Agustia (2020) and Dey (2020) for voluntary regimes. IR quality also leads to lower agency costs and thus to better stock liquidity in voluntary IR settings (Obeng et al., 2020b; Pavlopoulos et al., 2017).

\subsubsection{Cost of capital}

The holistic value creation and integrated thinking approach of the IR framework (IIRC, 2013) should allow investors to be better informed about a firm's value drivers, business model, and related business risks. This improved provision information should lead to decreased information asymmetry and, thus, to reduced cost of capital (Barth et al., 2017). Cost of capital (cost of equity and debt) represents an inverse component of firm value. There are indications that $I R$ adoption reduces the total cost of capital (Vena et al., 2020), cost of equity (Garcia-Sanchez \& NogueraGamez, 2017b) and cost of debt (Muttakin et al., 2020; South Africa; Gerwanski, 2020; international setting). IR quality is also connected with lower costs of equity in voluntary (Vitolla et al., 2019, b, c) and mandatory IR regimes (Zhou et al., 2017). However, Barth et al.'s (2017) results in South Africa are inconclusive.

\subsubsection{Expected future cash flows}

Investors are especially interested in forecasting future cash flows. Few studies have analysed the impact of IR on the ability of investors to forecast cash flows (e.g., Barth et al., 2017; Flores et al., 2019). Integrated reports should strengthen investors' ability to estimate future cash flows, in comparison to stand-alone CSR reports 
or classical financial reports (Barth et al., 2017). Analyst forecast accuracy, dispersion and error represent well-known variables in archival research; they indicate the degree of information asymmetry (lower information asymmetry contributes to higher firm value) between firms and investors. Analyst coverage represents another variable, assuming a greater level of coverage by financial analysts and increased firm attraction for investors. In view of IR adoption, prior research has found quite homogeneous results: Flores et al. (2019) reported that IR adoption increases both analyst coverage and analyst forecast accuracy. Other studies have documented that analyst forecast error decreases in mandatory (Bernardi \& Stark, 2018) and voluntary IR regimes (Garcia-Sanchez \& Noguera-Gamez, 2017a, b). Similar results, based on IR quality, are present in South Africa. Zhou et al. (2017) found a negative relationship between IR quality, analyst forecast error, and dispersion. Other studies have been rather inconclusive (Barth et al., 2017; Wahl et al., 2020). Caglio et al. (2020) did not document any link between IR readability and analyst forecasts and found a negative link between IR tone bias and analyst forecast dispersion in the South African mandatory IR setting.

\subsection{Moderator and mediator analysis}

Archival research on (non) financial reporting and performance has included possible moderator and mediator variables with a clear focus on moderators. Researchers have analysed whether the link between certain governance-, performance-, or reporting-related determinants of IR are strengthened or weakened by other factors. The link between IR and firm value may also be moderated or even mediated by additional variables. We differentiate between three types of moderator analysis in our literature review:

(1) IR variables may moderate relationships between non-IR variables.

(2) IR variables may moderate determinants and consequences of IR.

(3) Non-IR variables may moderate the consequences of IR on firm value.

\subsubsection{IR moderator variables}

Here we have emphasised the results of studies on IR variables that moderate other non-IR-links. Albitar and Hussainey (2020) found the positive link between CSR reporting and financial performance to be moderated by $I R$ adoption. IR adoption also moderates the positive relationship between CSR performance and the market value of equity (Loprevite et al., 2018). Graßmann (2020) documented that IR adoption positively moderates environmental expenditures and firm value, for firms with either a low or a high level of expenditures. However, the same author reported a negative moderating effect for "stuck in the middle" firms, indicating a non-linear relationship (Graßmann, 2020). Mervelskemper and Streit (2017) also noted inconclusive results.

Based on the South African IR regime, Muttakin et al. (2020) included IR adoption as a moderator on the negative link between earnings quality and cost of debt 
and found supportive results. According to Caglio et al. (2020), IR assurance compensates for poor IR readability (IR tone bias) and may be linked with increased firm reputation in South Africa. However, Landau et al. (2020) have stated that IR assurance by a Big Four audit firm and recognition of the Global Reporting Initiative (GRI) standards do not moderate the relationship between IR adoption and the market value of equity in voluntary IR settings. Gal and Akisik (2020) and Akisik and Gal (2019) found that IR assurance by an accounting firm moderates the link between IR adoption and financial performance as well as between IR adoption and the market value of equity. Maroun (2019) noted that IR assurance by a Big Four audit firm strengthens the positive impact of IR assurance on IR quality in South Africa.

\subsubsection{Non-IR moderator variables on the consequences of IR on firm value}

Garcia-Sanchez et al. (2019), Garcia-Sánchez et al. 2020) have noted that munificence strengthens the positive (corporate) governance-IR adoption link and growth opportunities moderate the negative link between CEO power and IR adoption. Most moderator analyses relate to the financial consequences of IR adoption and quality. Two studies of this type focus on the mandatory IR regime in South Africa (Lee \& Yeo, 2016; Zhou et al., 2017).Lee and Yeo (2016)'s study indicated that organisational complexity and external financing needs moderate the impact of IR quality on Tobin's Q. According to Zhou et al. (2017), low analyst following moderates the negative effect of IR quality on cost of equity. Cultural aspects, especially low power distance, strong collectivism and masculinity, moderate the negative impact of IR adoption on cost of capital (Vena et al., 2020). According to Gal and Akisik (2020), the effectiveness of internal control systems moderates the impact of IR adoption on the market value of equity. Cortesi and Vena (2019) could not find any moderator effect of geographical provenance, countries' economic structure and legal system on this link. Likewise, industry does not moderate the relationship between IR quality and CAR (Cosma et al., 2018). Flores et al. (2019) found that the link between IR adoption and analyst forecast accuracy is strengthened by a North American (case law) regime. In contrast to this, code law regimes and diversified firms strengthen the negative impact of IR quality on agency costs (Obeng et al., 2020b). According to Garcia-Sanchez and Noguera-Gamez (2017a), earnings quality and investor protection moderate the negative link between IR adoption and analyst forecast error. Gerwanski (2020) stressed that lower CSR performance and environmentally sensitive industries moderate the negative link between IR adoption and cost of debt.

\subsubsection{Mediator analysis}

In contrast to the increased number of moderator analyses during the last years, there has been little mediator analysis in prior IR research. We recognise just two studies in the South African mandatory IR setting (Bernardi \& Stark, 2018; Lemma et al., 2019), that have included a mediator analysis in their design. Lemma et al. (2019) stressed that earnings quality mediated the negative link between IR adoption 
and leverage in South Africa. According to Bernardi and Stark (2018), the negative relationship between IR adoption and analyst forecast error was mediated by CSR performance.

\subsection{Results}

Table 3 gives an overview of positive (+), negative $(-)$ and inconclusive $( \pm)$ significant results in the IR studies included in our literature review. We rely on the vote counting technique. While many studies concentrate on corporate governancerelated determinants, the impact of board composition, ownership structure and stakeholder pressure on IR adoption is inconclusive. This can be justified either by the heterogeneous significances found (board composition) or the low volume of studies (ownership structure and stakeholder pressure). While similar results are present for the link between ownership structure and IR quality, board composition (board effectiveness), and stakeholder pressure promote IR quality. The studies considering country-related governance variables are few and heterogeneous in their results. No tendencies toward any impact on IR adoption and IR quality can thus be stated. Interestingly, (non) financial performance leads to greater IR adoption and

Table 3 Vote counting results for the included variables in the literature review

\begin{tabular}{|c|c|c|c|c|c|c|}
\hline \multirow{2}{*}{$\begin{array}{l}\text { Determinants/consequences } \\
\text { of IR }\end{array}$} & \multicolumn{3}{|l|}{ IR adoption } & \multicolumn{3}{|l|}{ IR quality } \\
\hline & $\begin{array}{l}+ \\
\text { (pos. sign.) }\end{array}$ & $\begin{array}{l}- \\
\text { (neg. sign.) }\end{array}$ & $\begin{array}{l} \pm \\
\text { (insign.) }\end{array}$ & $\begin{array}{l}+ \\
\text { (pos. sign.) }\end{array}$ & $\begin{array}{l}- \\
\text { (neg. sign.) }\end{array}$ & $\begin{array}{l} \pm \\
\text { (insign.) }\end{array}$ \\
\hline
\end{tabular}

(1) Corporate governance

$\begin{array}{lllllll}\text { (a) Board composition } & 8 & 0 & 7 & 22 & 2 & 7 \\ \text { (b) Ownership structure } & 3 & 0 & 1 & 2 & 3 & 1 \\ \begin{array}{l}\text { (c) Stakeholder pressure } \\ \text { (2) Country-related governance }\end{array} & 2 & 0 & 1 & 9 & 0 & 4 \\ \text { (a) Civil law } & 2 & 0 & 4 & 1 & 0 & 2 \\ \text { (b) Legal enforcement } & 3 & 0 & 1 & 0 & 0 & 0 \\ \text { (c) Investor protection } & 1 & 1 & 2 & 0 & 1 & 0 \\ \text { (d) Culture } & 8 & 1 & 5 & 2 & 2 & 3\end{array}$

(3) (Non) financial performance and reporting

$\begin{array}{lllllll}\text { (a) Performance } & 12 & 1 & 6 & 8 & 1 & 4 \\ \text { (b) Reporting } & 1 & 0 & 1 & 2 & 1 & 2\end{array}$

(4) Consequences on firm value

\begin{tabular}{|c|c|c|c|c|c|}
\hline $\begin{array}{l}\text { (a) Total performance } \\
\text { measure }\end{array}$ & 11 & 2 & 1 & 12 & 1 \\
\hline $\begin{array}{l}\text { (b) Stock liquidity (inverse: } \\
\text { bid-ask-spread) }\end{array}$ & 0 & 0 & 0 & 5 & 1 \\
\hline (c) Cost of capital (inverse) & 0 & 4 & 0 & 0 & 2 \\
\hline $\begin{array}{l}\text { (d) Expected future cash } \\
\text { flows }\end{array}$ & 4 & 0 & 0 & 2 & 0 \\
\hline
\end{tabular}


quality by tendency. IR strategies may be promoted by board monitoring actions as well as by firm-related incentives. In contrast to this, there are not yet enough studies.

Finally, the studies included regarding the consequences of IR on firm value clearly indicate that total performance measures are positively linked with both IR adoption and quality. However, we note that few studies have considered specific components of firm value, such as liquidity, cost of capital, or expected future cash flows. In summary, there seems to be a business case argument for IR, as the capital market positively values IR strategies. In comparison to IR quality, we must recognise the differences between voluntary IR regimes and the mandatory South African setting when addressing studies on IR adoption. The South African setting was applied mainly to analyse the consequences of IR adoption on firm value. Interestingly, we do not see major differences in research results based on voluntary and mandatory settings. Instead, the business case for IR seems to be relevant in both settings, based on total performance measures.

Figure 2, based on our initial research framework, gives a summary of our key vote counting results on archival IR research. First, board composition and stakeholder pressure, as subgroups of corporate governance, are significantly positively related with IR quality. Second, (non) financial performance leads to increased IR adoption and IR quality. Third, both IR adoption and IR quality increase total performance measures-and thus firm value.

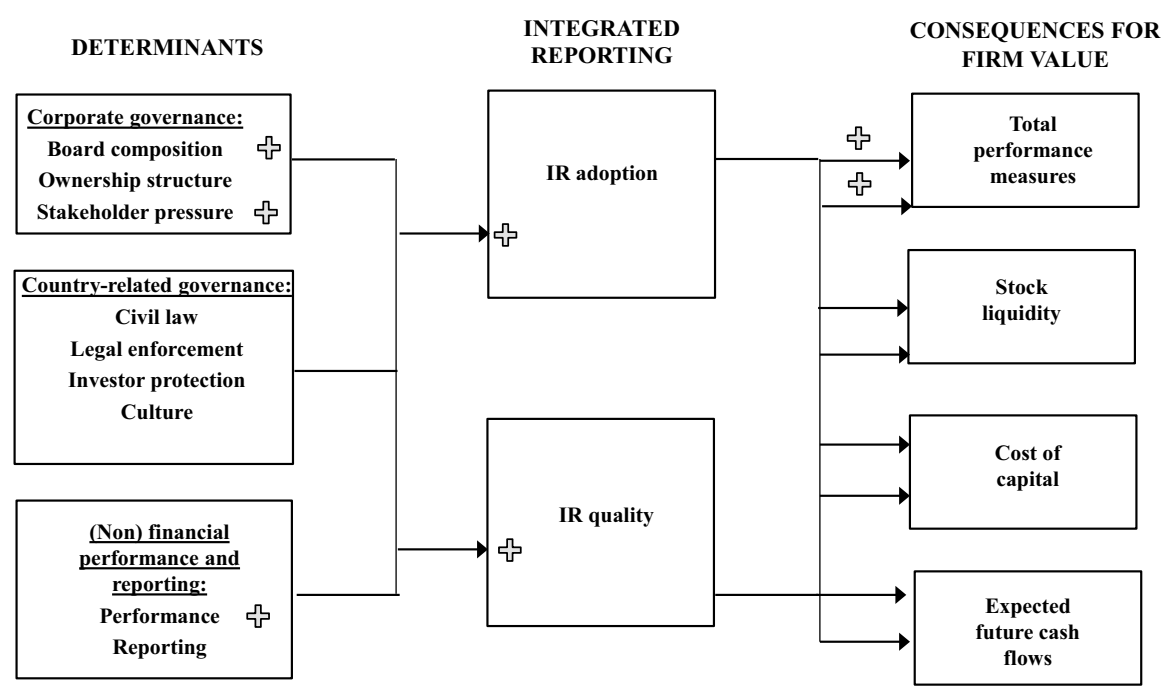

Fig. 2 Key findings of the literature review 


\section{Implications for future research}

\subsection{Methodological implications}

One of the key challenges in IR is the presence of high levels of managerial discretion (e.g., in terms of definition, assessment and information provided around the firm's 'capitals' or the materiality of information (Gerwanski et al., 2019). Thus, in business practice, IR lacks homogeneity and comparability between firms. In line with legitimacy theory, major risks include managerial greenwashing and impression management by 'rebranding' the classical annual report as an integrated report without any substantive change in the management system (Rivera-Arrubla et al., 2017). We appreciate that many studies measure IR quality, rather than just focussing on IR adoption. Yet the content analysis of IR and the generation of scoring criteria, in line with the IIRC Framework (IIRC, 2013), is linked with heterogeneous IR variables. In some research designs, there is no clear separation between CSR reporting and IR. Thus, future researchers should address 'real' integrated reports that are clearly linked to the IIRC framework, integrated thinking, management control processes, and risk management (e.g., based on major IR principles like materiality, conciseness, and connectivity). The risk of information overload with IR can also be reduced by a strong focus on the materiality principle in line with stakeholders' interests. Thus, we recommend the inclusion of materiality disclosure in IR quality studies (Fasan \& Mio, 2017; Gerwanski et al., 2019). To achieve this, a critical discussion on prior IR quality proxies will be most useful. No study, to date, has included a representative stakeholder dialogue on the relevant evaluation criteria for IR quality. In our literature review, some studies have tried to operationalise IR quality via "objective" means, for example, based on the "EY Excellence in Integrated Reporting Awards' score in South Africa (e.g., Barth et al., 2017). Along with classical content analysis and scoring methods, scholars refer to the readability of IR by textual analyses to assess its quality (Melloni et al., 2017). The intention of the narrative reporting medium to apply "plain language over the use of jargon or highly technical terminology" (IIRC, 2013, p. 21), is also relevant to IR. Textual analysis and using big data analytics, such as artificial intelligence or machine learning, represent innovative and relevant tools to create additional IR quality measures. One major challenge is the combination of archival data with primary data, based on interviews and surveys of top and middle management on IR implementation, to analyse IR quality.

From a methodological point of view, future studies should recognise several shortcomings in the prior research. First, they should address endogeneity concerns (e.g., reversed causality) in more detail (Wintoki et al., 2012). Advanced analytical approaches, including dynamic regression models (Generalised method of moments [GMM] estimation), instrumental variable (IV) approaches or simultaneous equations models [SEM]) are relevant to recognize concerns in IR research due to reversed causality or omitted variables (Wintoki et al., 2012). The authors assume that significant relationships between CSR and firm value may be raised by recognising "classical" OLS regressions in comparison to advanced regression models. 
Second, prior research includes mainly linear regression models, indicating that a maximum level of governance, (non) financial performance and reporting will be useful to adopt IR or increase its quality. Moreover, in line with archival research on related CSR topics, an optimal level of those indicators and a non-linear relationship seem more realistic (indicating a U-shape or inverted U-shape curve).

\subsection{Content-related implications}

While prior research on the corporate governance determinants of IR has notably increased in the past few years, "classical" board effectiveness proxies are generally applied (e.g., gender diversity, board size, board meeting frequency). We recommend adding behavioural corporate governance aspects with increased relevance to other related research topics. Managers' education and professional backgrounds (Lewis et al., 2014), personality and preferences (Gibbins et al., 1990), and sustainability-related attitudes (Helfaya \& Moussa, 2017) can also have a major influence on voluntary disclosure. Thus, researchers should analyse the effects of CEO and CFO demographic (e.g., gender, age, experience, education) or behavioural (e.g., altruism, narcissism, overconfidence) characteristics on IR strategies. Non-financial components in a firm's management compensation (e.g., Davila \& Venkatachalam, 2004; O'Connell \& O'Sullivan, 2014) are also given more importance in business practice, according to legitimacy and stakeholder theory. Sustainability management goals or management incentives, such as the recognition of social and environmental goals in compensation contracts, should increase the motivation of top managers to adopt IR with an appropriate level of quality (Winschel and Stawinoga 2019). While research on the effects of audit committee composition (e.g., effectiveness, size, expertise, independence, etc.) on IR has begun, we have identified some major research gaps in this area. Monitoring IR requires a combination of financial and sustainability expertise in audit committees. Also of key relevance is research on other committees, especially sustainability committees and Chief Sustainability Officers (CSO), and on their interaction with audit committees (Velte \& Stawinoga, 2020).

In contrast with research considering the audit committee as an internal corporate governance institution, extremely little archival research has analysed to date the impact of IR assurance on IR quality or the consequences of IR assurance on firm value (e.g., Velte \& Stawinoga, 2017a). In view of the increased relevance of empirical research on CSR assurance, future studies should also evaluate whether the choice of a specific IR assurance provider (professional accountant versus strategic consultant) and the assurance level (reasonable versus limited assurance) influence firm reputation and thus firm value. The literature states that a higher assurance level goes along with a higher reliability perception by stakeholders (Fuhrmann et al., 2017; Hasan et al., 2003). These assumptions should also be recognised in future archival IR research. Meanwhile, assurers' lack of IR-related experience and firms' insufficient implementation of adequate IR reporting infrastructures may question the value of IR by stakeholders (de Villiers et al., 2014; Maroun, 2017). 
While we recognise a steady increase in IR research on board composition, we know very little about the impact of ownership structure, especially institutional ownership, on IR. Intensive monitoring by shareholders, for example, by sustainable investors, should motivate top managers to adopt IR of high quality. Sustainable investors are of increasing importance to corporations (Renneboog et al., 2008). They are key players in (non) financial shareholder activism, through, for example, the channel of "say on pay" voting Future researchers should evaluate the effect of sustainable investors, based, for example, on signing the UN Principles for Sustainable Investors (PRI) on IR.

Shifting from corporate governance to country-specific governance factors, we identify a research gap on the separation between one-tier (e.g., UK) and two-tier (e.g., Germany) systems. Two-tier systems are rather important in some regimes, such as in those of Continental Europe, and have a traditional focus on internal monitoring by supervisory boards. Given that internal monitoring in two-tier systems tend to be linked with higher independence, but with decreased expertise (e.g., Maassen and van den Bosch 1999), it would be worth investigating the implications of the one-tier and two-tier system in cross-country research designs. While most studies included in this review refer to an international sample or to the South African setting, a special focus on the European Union (EU) (as a current promoter of sustainable finance, governance and reporting due to the recent "green deal" project) and on environmental sensitive industries within the EU would be useful and innovative. In comparison to countries' legal systems, which have been included in prior archival IR research, it would be informative to include regulatory and legal aspects that might affect the diffusion and implementation of IR as an "exogenous shock". These might include, for examples, the effect of recent EU regulations (e.g., the EU "CSR" directive 2014/95/EU or the EU "green taxonomy") on IR adoption and quality.

There is relatively little archival IR research on (non) financial performance and reporting as IR determinants, compared to governance-related aspects. While some researchers include (non) financial reporting and performance as determinants of IR strategies, we know very little about the interplay between earnings management and IR. As IR indicates a clear interaction among the six capitals, increased levels of of earnings management may have major effects on IR, both positive and negative. The association between IR and earnings quality should also be reassessed not just by means of accruals models, but also including real earnings management (Roychowdhury, 2006). Other firm-specific characteristics, such as size, age, and industry, are often included as controls, but are very rarely recognised as independent variables in prior archival IR research. Factors like organisational complexity (Lee \& Yeo, 2016) or employee relations management should also form part of future research. 


\section{Summary}

Over the past decade, the relevance of IR has increased from the perspective of research as well as regulatory and business practice. The goal of IR is a clear connection between financial, manufactured, intellectual, human, social and relationship and natural capitals (IIRC, 2013), with a main focus on the materiality principle and the integrated thinking approach. IR is assumed to help overcome the risks of greenwashing policy and information overload, which have been attributed to stand-alone CSR reports since the financial crisis of 2008-2009 (Mahoney et al., 2013). In line with increased information demands by shareholders and other stakeholder groups, IR should include both material economic information (financial and manufactured capitals, based on financial statements) and information regarding environmental, social and intellectual capitals within strategic and operational goals (IIRC, 2013). The 'integrated thinking' concept and the holistic view of value creation are connected with a significant change process in the top management. The current discussion around climate change policies and $\mathrm{C} 02$ disclosures stresses the need for a detailed integration of social and environmental risks in financial management and risk management processes (Eccles \& Krzus, 2019). Thus, IR represents the next step on the path of business reporting and complements or may even substitute stand-alone CSR reporting in the long run. However, as the current IIRC framework (IIRC, 2013) is principle based, we note increased levels of managerial discretion and thus a limited comparability of IR from an international perspective (Flower, 2015). As IR is still voluntary in most regimes (with the exception of listed firms in South Africa), IR adoption and IR quality are the two most important variables in IR archival research to date. As we integrate greenwashing and information overload as major challenges of IR, addressing IR quality in archival research is more useful than the inclusion of IR adoption. While there are some existing literature reviews on IR (e.g., de Villiers et al., 2017b), we offer the first comprehensive, theory-based literature review on the business case (Schaltegger et al., 2019; Carroll and Shaban 2010) for IR, which systematically focusses on 85 empirical-quantitative (archival) studies. Our legitimacy- and stakeholder-theoretical framework implies that strong monitoring tools (governance) and (non) financial incentives (performance and reporting) drive IR strategies and that IR will also be linked with increased firm value.

Our literature review makes key contributions to the prior research on IR. First, we structure this growing research field into areas that separately focus on (1) both firm- and country-related governance factors; (2) (non) financial performance and reporting-related drivers; and (3) consequences of IR on firm value in line with our business case argument. As greenwashing behaviour and information overload may impair the relevance of IR for shareholders and other stakeholders, we clearly differentiate between IR adoption and IR quality in our literature review. (4) We likewise include moderator and mediator analyses in IR research, as additional requirements for a successful IR strategy. Second, we prepare a structured list of variables and proxies used in the studies and note their main statistical outcome via vote counting technique. By mapping prior researched relationships, we emphasise those IR 
topics that remain under-researched. Third, we make useful recommendations from a methodological and content-related perspective for future IR research. Our literature review indicates that board composition and stakeholder pressure, as corporate governance measures, tend to lead to improved IR quality. There are also indications that (non) financial performance increases IR adoption and quality. Both IR adoption and IR quality are also connected with higher firm value, based on total performance measures. There are indications that a business case exists for IR in corporate practice. We do not see major differences between voluntary and mandatory IR settings (South Africa) in the studies we have included.

Our analysis is not just useful for researchers, but also for regulatory bodies and business practice. This is because, first, we provide evidence that a successful IR strategy may lead to improved firm value in line with the business case argument for IR. Top management should be motivated to add IR, after gaining learning effects from stand-alone CSR reports, since IR may significantly contribute to firm reputation and increased stakeholder trust. To increase top managers' motivation to strengthen their IR efforts, governance mechanisms, used as monitoring tools, and (non) financial incentives are important. Second, heterogeneous research designs stress the interdisciplinarity of IR-related issues (e.g., finance and accounting department, IT, marketing, and sustainability). Integrated thinking is not just necessary for reporting reasons, but also to reorganise the management and control systems. Third, while financial determinants and consequences were mainly included in prior research, recent IR research also focusses on non-financial items. Business practice should thus not classify IR as a one-sided shareholder tool, because it is also very useful for other stakeholders (e.g., customers or suppliers). Fourth, in line with the current regulatory discussion on mandatory climate change reporting (Eccles and Krzus 2019), non- financial issues should be clearly connected with advanced analytic tools, such as artificial intelligence or block chain technology (Wanner \& Janiesch, 2019). While financial reporting processes are well established within PIEs, many companies show critical weaknesses in quantifying non-financial goals and key performance indicators (KPI). IR that is solely qualitative will not lead to increased decision usefulness for stakeholders. Innovations in digital transformation and stakeholder pressure on sustainability can be classified as complementary value drivers, which should be a useful motivator for IR adoption and IR quality. 
Appendix 1 Archival research on governance-related determinants of IR

\begin{tabular}{|c|c|c|c|c|c|c|}
\hline Year & Author(s) & Reference & $\begin{array}{l}\text { Country } \\
\text { Sample size } \\
\text { Period }\end{array}$ & $\begin{array}{l}\text { Independent } \\
\text { variable(s) }\end{array}$ & $\begin{array}{l}\text { Dependent } \\
\text { variable(s) }\end{array}$ & $\begin{array}{l}\text { Significant } \\
\text { results }\end{array}$ \\
\hline 2020 & $\begin{array}{l}\text { Chouaibi and } \\
\text { Hichri }\end{array}$ & $\begin{array}{l}\text { International } \\
\text { Journal of } \\
\text { Law and } \\
\text { Manage- } \\
\text { ment }\end{array}$ & $\begin{array}{l}\text { International } \\
\quad \text { (Europe) } \\
130 \text { firms } \\
2017\end{array}$ & $\begin{array}{l}\text { Stakeholder } \\
\text { pressure } \\
\text { (auditor } \\
\text { industry } \\
\text { spe- } \\
\text { cialization } \\
\text { (dummy) } \\
\text { Code of } \\
\text { ethics exist- } \\
\text { ence in the } \\
\text { audit firm } \\
\text { (dummy) } \\
\text { Big four } \\
\text { audit firm } \\
\text { (dummy) } \\
\text { Behavioral } \\
\text { skills in the } \\
\text { audit firm } \\
\text { (dummy)) }\end{array}$ & $\begin{array}{l}\text { IR quality } \\
\text { (score; } \\
\text { AssetFour) }\end{array}$ & $\begin{array}{l}+ \\
+ \\
\pm \\
\pm\end{array}$ \\
\hline 2020 & $\begin{array}{l}\text { Garcia- } \\
\text { Sanchez } \\
\text { et al }\end{array}$ & $\begin{array}{l}\text { Meditari } \\
\text { Account- } \\
\text { ancy } \\
\text { Research }\end{array}$ & $\begin{array}{l}\text { International } \\
1588 \text { firms } \\
2009-2017\end{array}$ & $\begin{array}{l}\text { Board } \\
\text { composi- } \\
\text { tion (CEO } \\
\text { power } \\
\text { (index)) } \\
\text { Moderators: } \\
\text { information } \\
\text { asymmetry } \\
\text { (analyst } \\
\text { forecast } \\
\text { accuracy), } \\
\text { financial } \\
\text { constraints } \\
\text { (Kaplan- } \\
\text { Zingales } \\
\text { index), } \\
\text { firms' } \\
\text { incentives } \\
\text { (interaction } \\
\text { of two mod- } \\
\text { erators) }\end{array}$ & $\begin{array}{l}\text { IR adoption } \\
\text { (dummy) }\end{array}$ & $\begin{array}{l}- \\
\text { Modera- } \\
\text { tor: more } \\
\text { pronounced } \\
\text { by growth } \\
\text { opportunity }\end{array}$ \\
\hline
\end{tabular}




\begin{tabular}{|c|c|c|c|c|c|c|}
\hline Year & Author(s) & Reference & $\begin{array}{l}\text { Country } \\
\text { Sample size } \\
\text { Period }\end{array}$ & $\begin{array}{l}\text { Independent } \\
\text { variable(s) }\end{array}$ & $\begin{array}{l}\text { Dependent } \\
\text { variable(s) }\end{array}$ & $\begin{array}{l}\text { Significant } \\
\text { results }\end{array}$ \\
\hline 2020 & Graßmann & $\begin{array}{l}\text { Journal of } \\
\text { Cleaner } \\
\text { Production }\end{array}$ & $\begin{array}{l}\text { International } \\
2012-2017 \\
8992 \text { firm- } \\
\text { year obser- } \\
\text { vations }\end{array}$ & $\begin{array}{l}\text { CSR per- } \\
\text { formance } \\
\text { (environ- } \\
\text { mental } \\
\text { expendi- } \\
\text { tures } \\
\text { Social expen- } \\
\text { ditures) } \\
\text { Moderator: } \\
\text { IR adoption } \\
\text { (dummy) }\end{array}$ & $\begin{array}{c}\text { Total per- } \\
\text { formance } \\
\text { measures } \\
\text { (market } \\
\text { value of } \\
\text { equity) }\end{array}$ & $\begin{array}{l}\text { Environmental } \\
\text { expenditures: } \\
\text { u-shaped link } \\
\text { Social expendi- } \\
\text { tures: inverted } \\
\text { u-shaped link } \\
\text { Moderator: IR } \\
\text { positively } \\
\text { moderate } \\
\text { environmen- } \\
\text { tal expen- } \\
\text { ditures and } \\
\text { firm value } \\
\text { for firms } \\
\text { with either } \\
\text { a low or } \\
\text { high level of } \\
\text { expenditures; } \\
\text { negative mod- } \\
\text { erating effect } \\
\text { for "stuck in } \\
\text { the middle" }\end{array}$ \\
\hline 2020 & Marrone & $\begin{array}{l}\text { International } \\
\text { Journal of } \\
\text { Business } \\
\text { and Man- } \\
\text { agement }\end{array}$ & $\begin{array}{l}\text { International } \\
139 \text { firms } \\
\text { N.A }\end{array}$ & $\begin{array}{l}\text { Board com- } \\
\text { position } \\
\text { (board size } \\
\text { Board aver- } \\
\text { age age } \\
\text { Board gender } \\
\text { diversity } \\
\text { CEO duality) }\end{array}$ & $\begin{array}{l}\text { IR quality } \\
\text { (score) }\end{array}$ & $\begin{array}{l}+ \\
\pm \\
+ \\
-\end{array}$ \\
\hline $2020 \mathrm{a}$ & Raimo et al & $\begin{array}{l}\text { Business } \\
\text { Strategy and } \\
\text { the Environ- } \\
\text { ment }\end{array}$ & $\begin{array}{l}\text { International } \\
125 \text { firms } \\
2017\end{array}$ & $\begin{array}{l}\text { Board } \\
\text { composi- } \\
\text { tion (audit } \\
\text { committee } \\
\text { size } \\
\text { Audit com- } \\
\text { mittee inde- } \\
\text { pendence } \\
\text { Audit com- } \\
\text { mittee } \\
\text { meeting } \\
\text { frequency } \\
\text { Audit com- } \\
\text { mittee } \\
\text { financial } \\
\text { expertise) }\end{array}$ & $\begin{array}{l}\text { IR quality } \\
\text { (score) }\end{array}$ & $\begin{array}{l}+ \\
+ \\
+ \\
\pm\end{array}$ \\
\hline
\end{tabular}




\begin{tabular}{|c|c|c|c|c|c|c|}
\hline Year & Author(s) & Reference & $\begin{array}{l}\text { Country } \\
\text { Sample size } \\
\text { Period }\end{array}$ & $\begin{array}{l}\text { Independent } \\
\text { variable(s) }\end{array}$ & $\begin{array}{l}\text { Dependent } \\
\text { variable(s) }\end{array}$ & $\begin{array}{l}\text { Significant } \\
\text { results }\end{array}$ \\
\hline $2020 b$ & Raimo et al & $\begin{array}{l}\text { Business } \\
\text { Strategy and } \\
\text { the Environ- } \\
\text { ment }\end{array}$ & $\begin{array}{l}\text { International } \\
152 \text { firms } \\
2017\end{array}$ & $\begin{array}{l}\text { Ownership } \\
\text { structure } \\
\text { (insti- } \\
\text { tutional } \\
\text { ownership } \\
\text { Ownership } \\
\text { concentra- } \\
\text { tion } \\
\text { Managerial } \\
\text { ownership } \\
\text { State owner- } \\
\text { ship) }\end{array}$ & $\begin{array}{l}\text { IR quality } \\
\text { (score) }\end{array}$ & $\begin{array}{l}+ \\
- \\
- \\
-\end{array}$ \\
\hline $2020 \mathrm{a}$ & Vitolla et al & $\begin{array}{l}\text { Corporate } \\
\text { Social } \\
\text { Responsi- } \\
\text { bility and } \\
\text { Environ- } \\
\text { mental } \\
\text { Manage- } \\
\text { ment }\end{array}$ & $\begin{array}{l}\text { International } \\
134 \text { firms } \\
\text { K.A }\end{array}$ & $\begin{array}{l}\text { Board com- } \\
\text { position } \\
\text { (board size } \\
\text { Board inde- } \\
\text { pendence } \\
\text { Board diver- } \\
\text { sity } \\
\text { Board activ- } \\
\text { ity) }\end{array}$ & $\begin{array}{l}\text { IR quality } \\
\text { (score) }\end{array}$ & $\begin{array}{l}+ \\
+ \\
+ \\
+\end{array}$ \\
\hline $2020 b$ & Vitolla et al & $\begin{array}{l}\text { Corporate } \\
\text { Governance }\end{array}$ & $\begin{array}{l}\text { International } \\
\quad(20 \text { coun- } \\
\quad \text { tries }) \\
87 \text { banks } \\
2017\end{array}$ & $\begin{array}{l}\text { Country- } \\
\text { related } \\
\text { governance } \\
\text { (civil law) }\end{array}$ & $\begin{array}{l}\text { IR quality } \\
\text { (scoring) }\end{array}$ & + \\
\hline $2020 d$ & Vitolla et al & $\begin{array}{l}\text { Corporate } \\
\text { Social } \\
\text { Responsi- } \\
\text { bility and } \\
\text { Environ- } \\
\text { mental } \\
\text { Manage- } \\
\text { ment }\end{array}$ & $\begin{array}{l}\text { International } \\
130 \text { firms } \\
2017\end{array}$ & $\begin{array}{l}\text { Board com- } \\
\text { position } \\
\text { (board size } \\
\text { Board inde- } \\
\text { pendence } \\
\text { Board diver- } \\
\text { sity } \\
\text { Board activ- } \\
\text { ity) }\end{array}$ & $\begin{array}{l}\text { Intellectual } \\
\text { capital } \\
\text { disclosure } \\
\text { quality in } \\
\text { integrated } \\
\text { reports } \\
\text { (score) }\end{array}$ & $\begin{array}{l}+ \\
+ \\
+ \\
+\end{array}$ \\
\hline 2020 & Wang et al & $\begin{array}{l}\text { European } \\
\text { Accounting } \\
\text { Review }\end{array}$ & $\begin{array}{l}\text { South Africa } \\
111 \text { firms } \\
2012-2015\end{array}$ & $\begin{array}{l}\text { Board } \\
\text { composi- } \\
\text { tion (board } \\
\text { effective- } \\
\text { ness } \\
\text { Audit com- } \\
\text { mittee } \\
\text { effective- } \\
\text { ness } \\
\text { CSR commit- } \\
\text { tee effec- } \\
\text { tiveness } \\
\text { CSR-related } \\
\text { manage- } \\
\text { ment com- } \\
\text { pensation) }\end{array}$ & $\begin{array}{l}\text { IR quality } \\
\text { (score; EY } \\
\text { ranking) } \\
\text { CSR assur- } \\
\text { ance use } \\
\text { CSR assur- } \\
\text { ance quality } \\
\text { (score) }\end{array}$ & $\begin{array}{l}+ \\
\text { (all) } \\
+ \\
\text { (all) } \\
+ \\
\text { (CSR govern- } \\
\quad \text { ance variables } \\
\quad \text { more signifi- } \\
\quad \text { cant) }\end{array}$ \\
\hline
\end{tabular}




\begin{tabular}{|c|c|c|c|c|c|c|}
\hline Year & Author(s) & Reference & $\begin{array}{l}\text { Country } \\
\text { Sample size } \\
\text { Period }\end{array}$ & $\begin{array}{l}\text { Independent } \\
\text { variable(s) }\end{array}$ & $\begin{array}{l}\text { Dependent } \\
\text { variable(s) }\end{array}$ & $\begin{array}{l}\text { Significant } \\
\text { results }\end{array}$ \\
\hline 2019 & Fuhrmann & $\begin{array}{l}\text { Meditary } \\
\text { Account- } \\
\text { ancy } \\
\text { Research }\end{array}$ & $\begin{array}{l}\text { International } \\
353 \text { reports } \\
2012-2016\end{array}$ & $\begin{array}{l}\text { Ownership } \\
\text { structure } \\
\text { (concentra- } \\
\text { tion) } \\
\text { Country- } \\
\text { related } \\
\text { governance } \\
\text { (civil law } \\
\text { Investor } \\
\text { protection } \\
\text { Culture } \\
\text { (Power } \\
\text { distance, } \\
\text { masculinity, } \\
\text { individual- } \\
\text { ism, long } \\
\text { term } \\
\text { orientation, } \\
\text { indulgence) } \\
\text { Stock market } \\
\text { importance }\end{array}$ & $\begin{array}{l}\text { IR adoption } \\
\text { (dummy) }\end{array}$ & $\begin{array}{l}+ \\
/ \\
+ \\
- \\
- \text { (power } \\
\text { distance, } \\
\text { masculin- } \\
\text { ity); } \pm(\text { indi- } \\
\text { vidualism, } \\
\text { long term } \\
\text { orientation, } \\
\text { indulgence) } \\
\pm\end{array}$ \\
\hline 2019 & $\begin{array}{l}\text { Garcia- } \\
\text { Sanchez } \\
\text { et al }\end{array}$ & $\begin{array}{l}\text { Corporate } \\
\text { Social } \\
\text { Responsi- } \\
\text { bility and } \\
\text { Environ- } \\
\text { mental } \\
\text { Manage- } \\
\text { ment }\end{array}$ & $\begin{array}{l}\text { International } \\
6442 \text { firm- } \\
\text { year obser- } \\
\text { vations } \\
\text { 2006-2014 }\end{array}$ & $\begin{array}{l}\text { Board effec- } \\
\text { tiveness } \\
\text { (independ- } \\
\text { ence, } \\
\text { gender } \\
\text { diversity, } \\
\text { experience, } \\
\text { expertise, } \\
\text { external } \\
\text { consultants) } \\
\text { Country- } \\
\text { related } \\
\text { governance } \\
\text { (investor } \\
\text { protection } \\
\text { (anti-self- } \\
\text { dealing } \\
\text { index, } \\
\text { creditor } \\
\text { protection } \\
\text { and capital } \\
\text { market } \\
\text { develop- } \\
\text { ment) } \\
\text { Transparency } \\
\text { Corruption } \\
\text { perception) } \\
\text { Moderator: } \\
\text { Munifi- } \\
\text { cence }\end{array}$ & $\begin{array}{l}\text { IR adoption } \\
\text { (dummy) }\end{array}$ & $\begin{array}{l}+ \\
+ \\
+ \\
\pm \\
\text { Moderator:+ }\end{array}$ \\
\hline
\end{tabular}




\begin{tabular}{|c|c|c|c|c|c|c|}
\hline Year & Author(s) & Reference & $\begin{array}{l}\text { Country } \\
\text { Sample size } \\
\text { Period }\end{array}$ & $\begin{array}{l}\text { Independent } \\
\text { variable(s) }\end{array}$ & $\begin{array}{l}\text { Dependent } \\
\text { variable(s) }\end{array}$ & $\begin{array}{l}\text { Significant } \\
\text { results }\end{array}$ \\
\hline 2019 & $\begin{array}{l}\text { Gerwanski } \\
\text { et al }\end{array}$ & $\begin{array}{l}\text { Business } \\
\text { Strategy and } \\
\text { the Environ- } \\
\text { ment }\end{array}$ & $\begin{array}{l}\text { International } \\
359 \text { firm-year } \\
\text { observa- } \\
\text { tions } \\
\text { 2013-2016 }\end{array}$ & $\begin{array}{l}\text { Board } \\
\text { composi- } \\
\text { tion (board } \\
\text { gender } \\
\text { diversity) } \\
\text { Reporting } \\
\text { (IR quality } \\
\text { (assurance; } \\
\text { dummy)) } \\
\text { Stakeholder } \\
\text { pressure } \\
\text { (Dow Jones } \\
\text { Sustainabil- } \\
\text { ity Index } \\
\text { (DJSI) } \\
\text { listing) }\end{array}$ & $\begin{array}{l}\text { IR quality } \\
\text { (materiality } \\
\text { disclosure; } \\
\text { score) }\end{array}$ & $\begin{array}{l}+ \\
+ \\
\pm\end{array}$ \\
\hline 2019 & Girella et al & $\begin{array}{l}\text { Business } \\
\text { Strategy and } \\
\text { the Environ- } \\
\text { ment }\end{array}$ & $\begin{array}{l}\text { International } \\
349 \text { firms } \\
2016\end{array}$ & $\begin{array}{l}\text { Board com- } \\
\text { position } \\
\text { (board size } \\
\text { Board gender } \\
\text { diversity } \\
\text { Board inde- } \\
\text { pendence) } \\
\text { Country- } \\
\text { related } \\
\text { governance } \\
\text { (corruption } \\
\text { perception } \\
\text { Risk rating } \\
\text { Culture (col- } \\
\text { lectivism, } \\
\text { feminism, } \\
\text { long-term } \\
\text { orientation) } \\
\text { Civil law) }\end{array}$ & $\begin{array}{l}\text { IR adoption } \\
\text { (dummy) }\end{array}$ & $\begin{array}{l}+ \\
\pm \\
\pm \\
+ \\
+ \\
+ \\
\pm\end{array}$ \\
\hline 2019 & $\begin{array}{l}\text { Graßmann } \\
\text { et al }\end{array}$ & $\begin{array}{l}\text { Sustainability } \\
\text { Accounting, } \\
\text { Manage- } \\
\text { ment and } \\
\text { Policy }\end{array}$ & $\begin{array}{l}\text { International } \\
169 \text { reports } \\
2013-2014\end{array}$ & $\begin{array}{l}\text { Ownership } \\
\text { structure } \\
\text { (concentra- } \\
\text { tion) }\end{array}$ & $\begin{array}{l}\text { IR quality } \\
\text { (integrated } \\
\text { thinking; } \\
\text { score) }\end{array}$ & + \\
\hline 2019 & Kim et al & Sustainability & $\begin{array}{l}\text { Korea } \\
4186 \text { firm- } \\
\text { year obser- } \\
\text { vations } \\
2005-2016\end{array}$ & $\begin{array}{l}\text { Stakeholder } \\
\text { pressure } \\
\text { (employee } \\
\text { pressure) }\end{array}$ & $\begin{array}{l}\text { IR adoption } \\
\text { (dummy) }\end{array}$ & $\begin{array}{l}+ \\
\text { (number of } \\
\quad \text { employees) }\end{array}$ \\
\hline
\end{tabular}




\begin{tabular}{|c|c|c|c|c|c|c|}
\hline Year & Author(s) & Reference & $\begin{array}{l}\text { Country } \\
\text { Sample size } \\
\text { Period }\end{array}$ & $\begin{array}{l}\text { Independent } \\
\text { variable(s) }\end{array}$ & $\begin{array}{l}\text { Dependent } \\
\text { variable(s) }\end{array}$ & $\begin{array}{l}\text { Significant } \\
\text { results }\end{array}$ \\
\hline 2019 & Maroun & $\begin{array}{l}\text { Journal of } \\
\text { Accounting } \\
\text { and Public } \\
\text { Policy }\end{array}$ & $\begin{array}{l}\text { South Africa } \\
42 \text { firms } \\
2010-2016\end{array}$ & $\begin{array}{l}\text { Reporting } \\
\text { (IR quality } \\
\text { (amount } \\
\text { of assured } \\
\text { informa- } \\
\text { tion) } \\
\text { Moderator: } \\
\text { Big four, } \\
\text { reasonable } \\
\text { assurance, } \\
\text { IR disclo- } \\
\text { sure option }\end{array}$ & $\begin{array}{l}\text { IR qual- } \\
\text { ity (EY } \\
\text { awards) }\end{array}$ & $\begin{array}{l}+ \\
\text { Modera- } \\
\quad \text { tor: }+ \text { Big four }\end{array}$ \\
\hline $2019 a$ & Vitolla et al & $\begin{array}{l}\text { Corporate } \\
\text { Social } \\
\text { Responsi- } \\
\text { bility and } \\
\text { Environ- } \\
\text { mental } \\
\text { Manage- } \\
\text { ment }\end{array}$ & $\begin{array}{l}\text { International } \\
145 \text { firms } \\
2011-2018\end{array}$ & $\begin{array}{l}\text { Ownership } \\
\text { structure } \\
\text { (concentra- } \\
\text { tion) } \\
\text { Stakeholder } \\
\text { pressure } \\
\text { (customer } \\
\text { pressure } \\
\text { (consumer } \\
\text { product } \\
\text { and service } \\
\text { industry; } \\
\text { dummy) } \\
\text { Environ- } \\
\text { mental } \\
\text { protection } \\
\text { organiza- } \\
\text { tions' } \\
\text { pressure } \\
\text { (important } \\
\text { impact on } \\
\text { environ- } \\
\text { ment; } \\
\text { dummy) } \\
\text { Employee } \\
\text { pressure } \\
\text { (total } \\
\text { employees) } \\
\text { mandatory } \\
\text { IR regime } \\
\text { (dummy)) }\end{array}$ & $\begin{array}{l}\text { IR quality } \\
\text { (score) }\end{array}$ & $\begin{array}{l}+ \\
+ \\
+ \\
+ \\
+\end{array}$ \\
\hline
\end{tabular}




\begin{tabular}{|c|c|c|c|c|c|c|}
\hline Year & Author(s) & Reference & $\begin{array}{l}\text { Country } \\
\text { Sample size } \\
\text { Period }\end{array}$ & $\begin{array}{l}\text { Independent } \\
\text { variable(s) }\end{array}$ & $\begin{array}{l}\text { Dependent } \\
\text { variable(s) }\end{array}$ & $\begin{array}{l}\text { Significant } \\
\text { results }\end{array}$ \\
\hline $2019 b$ & Vitolla et al & $\begin{array}{l}\text { Business } \\
\text { Strategy and } \\
\text { the Environ- } \\
\text { ment }\end{array}$ & $\begin{array}{l}\text { International } \\
135 \text { firms } \\
2017\end{array}$ & $\begin{array}{l}\text { Country- } \\
\text { related } \\
\text { governance } \\
\text { (culture } \\
\text { (power dis- } \\
\text { tance, indi- } \\
\text { vidualism, } \\
\text { masculinity, } \\
\text { indulgence, } \\
\text { uncertainty } \\
\text { avoidance, } \\
\text { long-term } \\
\text { orientation) }\end{array}$ & $\begin{array}{l}\text { IR quality } \\
\text { (Score) }\end{array}$ & $\begin{array}{l}\text { - (with the } \\
\text { exception of } \\
\text { uncertainty } \\
\text { avoidance }+ \text {; } \\
\text { long-term ori- } \\
\text { entation: } \pm \text { ) }\end{array}$ \\
\hline 2018 & Alfiero et al & $\begin{array}{c}\text { Corporate } \\
\text { Board }\end{array}$ & $\begin{array}{l}\text { International } \\
\quad \text { (Europe) } \\
1058 \text { firms } \\
2015\end{array}$ & $\begin{array}{l}\text { Board com- } \\
\text { position } \\
\text { (foreign } \\
\text { board } \\
\text { diversity } \\
\text { (percent- } \\
\text { age; at least } \\
\text { three) } \\
\text { Majority of } \\
\text { foreign } \\
\text { board mem- } \\
\text { bers from } \\
\text { feminine } \\
\text { countries } \\
\text { (dummy) } \\
\text { Board size }\end{array}$ & $\begin{array}{l}\text { IR adoption } \\
\text { (dummy; } \\
\text { yes/no) }\end{array}$ & $\begin{array}{l}\text { (but at least } \\
\text { three for- } \\
\text { eigns: }+ \text { ) } \\
+ \\
+\end{array}$ \\
\hline 2018 & $\begin{array}{l}\text { Garcia- } \\
\text { Sanchez \& } \\
\text { Noguera- } \\
\text { Gamez }\end{array}$ & $\begin{array}{l}\text { Australian } \\
\text { Accounting } \\
\text { Review }\end{array}$ & $\begin{array}{l}\text { International } \\
3294 \text { firm- } \\
\text { year obser- } \\
\text { vations } \\
\text { 2009-2013 }\end{array}$ & $\begin{array}{l}\text { Board com- } \\
\text { position } \\
\text { (Board size } \\
\text { Board gender } \\
\text { diversity) } \\
\text { Country- } \\
\text { related } \\
\text { governance } \\
\text { (Investor } \\
\text { protection } \\
\text { Civil law } \\
\text { Anti-director } \\
\text { rights } \\
\text { Legal } \\
\text { enforce- } \\
\text { ment) }\end{array}$ & $\begin{array}{l}\text { IR adoption } \\
\text { (dummy) }\end{array}$ & $\begin{array}{l} \pm \\
\pm \\
\pm \\
\pm \\
\pm \\
+\end{array}$ \\
\hline 2018 & Ghani et al & $\begin{array}{l}\text { International } \\
\text { Journal of } \\
\text { Manage- } \\
\text { rial and } \\
\text { Financial } \\
\text { Accounting }\end{array}$ & $\begin{array}{l}\text { Malaysia } \\
74 \text { firms } \\
2016\end{array}$ & $\begin{array}{l}\text { Stakeholder } \\
\text { pressure } \\
\text { (Big four } \\
\text { audit firm) }\end{array}$ & $\begin{array}{l}\text { IR quality } \\
\text { (scoring) }\end{array}$ & + \\
\hline
\end{tabular}




\begin{tabular}{|c|c|c|c|c|c|c|}
\hline Year & Author(s) & Reference & $\begin{array}{l}\text { Country } \\
\text { Sample size } \\
\text { Period }\end{array}$ & $\begin{array}{l}\text { Independent } \\
\text { variable(s) }\end{array}$ & $\begin{array}{l}\text { Dependent } \\
\text { variable(s) }\end{array}$ & $\begin{array}{l}\text { Significant } \\
\text { results }\end{array}$ \\
\hline 2018 & $\begin{array}{l}\text { Kilic \& } \\
\text { Kuzey }\end{array}$ & $\begin{array}{c}\text { Managerial } \\
\text { Auditing } \\
\text { Journal }\end{array}$ & $\begin{array}{l}\text { International } \\
55 \text { firm-year } \\
\text { observa- } \\
\text { tions } \\
2014\end{array}$ & $\begin{array}{l}\text { Board com- } \\
\text { position } \\
\text { (Board size } \\
\text { Board inde- } \\
\text { pendence } \\
\text { Board gender } \\
\text { diversity) }\end{array}$ & $\begin{array}{l}\text { IR quality } \\
\text { (forward- } \\
\text { looking } \\
\text { disclosure } \\
\text { index) }\end{array}$ & $\begin{array}{l} \pm \\
\pm \\
+\end{array}$ \\
\hline 2018 & Velte & $\begin{array}{l}\text { Problems and } \\
\text { Perspectives } \\
\text { in Manage- } \\
\text { ment }\end{array}$ & $\begin{array}{l}\text { International } \\
215 \text { firm-year } \\
\text { observa- } \\
\text { tions } \\
2014-2016\end{array}$ & $\begin{array}{l}\text { Board } \\
\text { composi- } \\
\text { tion (audit } \\
\text { committee } \\
\text { financial } \\
\text { expertise } \\
\text { Audit com- } \\
\text { mittee sus- } \\
\text { tainability } \\
\text { expertise) }\end{array}$ & $\begin{array}{l}\text { IR quality } \\
\text { (readability } \\
\text { score) }\end{array}$ & $\begin{array}{l}+ \\
+ \\
\text { More pro- } \\
\text { nounced by } \\
\text { combined } \\
\text { expertise }\end{array}$ \\
\hline 2017 & Fasan \& Mio & $\begin{array}{l}\text { Business } \\
\text { Strategy and } \\
\text { the Environ- } \\
\text { ment }\end{array}$ & $\begin{array}{l}\text { International } \\
65 \text { IIRC pilot } \\
\text { program } \\
\text { members } \\
2012-2013\end{array}$ & $\begin{array}{l}\text { Board com- } \\
\text { position } \\
\text { (board size } \\
\text { Board inde- } \\
\text { pendence } \\
\text { Board activity } \\
\text { Board gender } \\
\text { diversity } \\
\text { Country- } \\
\text { related } \\
\text { governance } \\
\text { (civil law) }\end{array}$ & $\begin{array}{l}\text { IR quality } \\
\text { (materiality } \\
\text { disclosure; } \\
\text { score) }\end{array}$ & $\begin{array}{l}- \\
\pm \\
\pm \\
- \\
\pm\end{array}$ \\
\hline 2017 & Melloni et al & $\begin{array}{l}\text { Journal of } \\
\text { Accounting } \\
\text { and Public } \\
\text { Policy }\end{array}$ & $\begin{array}{l}\text { International } \\
104 \text { firm-year } \\
\text { observa- } \\
\text { tions } \\
2013-2014\end{array}$ & $\begin{array}{l}\text { Governance } \\
\text { perfor- } \\
\text { mance }\end{array}$ & $\begin{array}{l}\text { IR quality } \\
\text { (Con- } \\
\text { ciseness } \\
\text { (length, } \\
\text { readability); } \\
\text { Complete- } \\
\text { ness (ESG } \\
\text { score); } \\
\text { tone) }\end{array}$ & \pm \\
\hline 2017 & $\begin{array}{l}\text { Pavlopoulos } \\
\text { et al }\end{array}$ & $\begin{array}{l}\text { Journal of } \\
\text { Multi- } \\
\text { national } \\
\text { Financial } \\
\text { Manage- } \\
\text { ment }\end{array}$ & $\begin{array}{l}\text { International } \\
82 \text { firms } \\
2011-2015\end{array}$ & $\begin{array}{l}\text { Board com- } \\
\text { position } \\
\text { (independ- } \\
\text { ent mem- } \\
\text { bers on the } \\
\text { nomination } \\
\text { and audit } \\
\text { committee) }\end{array}$ & $\begin{array}{l}\text { IR quality } \\
\text { (disclosure } \\
\text { index) }\end{array}$ & + \\
\hline
\end{tabular}




\begin{tabular}{|c|c|c|c|c|c|c|}
\hline Year & Author(s) & Reference & $\begin{array}{l}\text { Country } \\
\text { Sample size } \\
\text { Period }\end{array}$ & $\begin{array}{l}\text { Independent } \\
\text { variable(s) }\end{array}$ & $\begin{array}{l}\text { Dependent } \\
\text { variable(s) }\end{array}$ & $\begin{array}{l}\text { Significant } \\
\text { results }\end{array}$ \\
\hline 2017 & $\begin{array}{l}\text { Rivera- } \\
\text { Arrrubla } \\
\text { et al }\end{array}$ & $\begin{array}{l}\text { Social } \\
\text { Respon- } \\
\text { sibility } \\
\text { Journal }\end{array}$ & $\begin{array}{l}\text { International } \\
91 \text { firm-year } \\
\text { observa- } \\
\text { tions } \\
2011\end{array}$ & $\begin{array}{l}\text { Stakeholder } \\
\text { pressure } \\
\text { (Big four } \\
\text { audit firm) } \\
\text { IR quality } \\
\text { (assurance; } \\
\text { dummy)) } \\
\text { Country- } \\
\text { related } \\
\text { governance } \\
\text { (civil law) }\end{array}$ & $\begin{array}{l}\text { IR quality } \\
\text { (disclosure } \\
\text { index) }\end{array}$ & $\begin{array}{l}+ \\
\pm \\
\pm\end{array}$ \\
\hline 2016 & $\begin{array}{l}\text { Haji \& Ani- } \\
\text { fowose }\end{array}$ & $\begin{array}{c}\text { Managerial } \\
\text { Auditing } \\
\text { Journal }\end{array}$ & $\begin{array}{l}\text { South Africa } \\
246 \text { firm-year } \\
\text { observa- } \\
\text { tions } \\
2011-2013\end{array}$ & $\begin{array}{l}\text { Board } \\
\text { composi- } \\
\text { tion (audit } \\
\text { committee } \\
\text { effective- } \\
\text { ness } \\
\text { Audit com- } \\
\text { mittee size } \\
\text { Audit com- } \\
\text { mittee } \\
\text { activity } \\
\text { Audit com- } \\
\text { mittee inde- } \\
\text { pendence } \\
\text { Audit com- } \\
\text { mittee } \\
\text { financial } \\
\text { expertise } \\
\text { Audit com- } \\
\text { mittee } \\
\text { authority } \\
\text { Sustainability } \\
\text { committee) } \\
\text { Ownership } \\
\text { structure } \\
\text { (concentra- } \\
\text { tion) }\end{array}$ & $\begin{array}{l}\text { IR quality } \\
\text { (score) }\end{array}$ & $\begin{array}{l}+ \\
\pm \\
+ \\
\pm \\
\pm \\
+ \\
+ \\
+\end{array}$ \\
\hline 2016 & Lai et al & $\begin{array}{l}\text { Business } \\
\text { Strategy and } \\
\text { the Environ- } \\
\text { ment }\end{array}$ & $\begin{array}{l}\text { International } \\
52 \text { IR adop- } \\
\text { ters } \\
2009-2011\end{array}$ & $\begin{array}{l}\text { Governance } \\
\text { perfor- } \\
\text { mance }\end{array}$ & $\begin{array}{l}\text { IR adoption } \\
\text { (dummy) }\end{array}$ & + \\
\hline 2016 & $\begin{array}{l}\text { Stacchezzini } \\
\text { et al }\end{array}$ & $\begin{array}{l}\text { Journal of } \\
\text { Cleaner } \\
\text { Production }\end{array}$ & $\begin{array}{l}\text { International } \\
54 \text { firm-year } \\
\text { observa- } \\
\text { tions } \\
2011-2013\end{array}$ & $\begin{array}{l}\text { Board } \\
\text { composi- } \\
\text { tion (board } \\
\text { independ- } \\
\text { ence) }\end{array}$ & $\begin{array}{l}\text { IR quality } \\
\text { (sustaina- } \\
\text { bility action } \\
\text { disclosure) }\end{array}$ & - \\
\hline
\end{tabular}




\begin{tabular}{|c|c|c|c|c|c|c|}
\hline Year & Author(s) & Reference & $\begin{array}{l}\text { Country } \\
\text { Sample size } \\
\text { Period }\end{array}$ & $\begin{array}{l}\text { Independent } \\
\text { variable(s) }\end{array}$ & $\begin{array}{l}\text { Dependent } \\
\text { variable(s) }\end{array}$ & $\begin{array}{l}\text { Significant } \\
\text { results }\end{array}$ \\
\hline 2016 & Vaz et al & $\begin{array}{l}\text { Business } \\
\text { Ethics: A } \\
\text { European } \\
\text { Review }\end{array}$ & $\begin{array}{l}\text { International } \\
1449 \text { firm- } \\
\text { year obser- } \\
\text { vations } \\
2012\end{array}$ & $\begin{array}{l}\text { IR quality } \\
\text { (assurance; } \\
\text { dummy) } \\
\text { Country- } \\
\text { related } \\
\text { governance } \\
\text { (civil law } \\
\text { Investor } \\
\text { protection } \\
\text { Culture (Col- } \\
\text { lectivism; } \\
\text { Feminism)) }\end{array}$ & $\begin{array}{l}\text { IR adoption } \\
\text { (dummy) }\end{array}$ & $\begin{array}{l} \pm \\
\pm \\
\pm \\
+ \\
\text { (Collectivism) }\end{array}$ \\
\hline 2015 & Serafeim & $\begin{array}{r}\text { Journal of } \\
\text { Applied } \\
\text { Corporate } \\
\text { Finance }\end{array}$ & $\begin{array}{l}\text { USA } \\
1114 \text { firms } \\
2002-2010\end{array}$ & $\begin{array}{l}\text { Ownership } \\
\text { structure } \\
\text { (Long-term } \\
\text { investors } \\
\text { (difference } \\
\text { between the } \\
\text { percentage } \\
\text { of shares } \\
\text { held by } \\
\text { dedi- } \\
\text { cated and } \\
\text { transient } \\
\text { investors)) }\end{array}$ & $\begin{array}{l}\text { IR adoption } \\
\text { (dummy) }\end{array}$ & + \\
\hline 2015 & $\begin{array}{l}\text { Sierra-Garcia } \\
\text { et al }\end{array}$ & $\begin{array}{l}\text { Corporate } \\
\text { Social } \\
\text { Responsi- } \\
\text { bility and } \\
\text { Environ- } \\
\text { mental } \\
\text { Manage- } \\
\text { ment }\end{array}$ & $\begin{array}{l}\text { International } \\
7344 \text { firm- } \\
\text { year obser- } \\
\text { vations } \\
\text { 2009-2011 }\end{array}$ & $\begin{array}{l}\text { Stakeholder } \\
\text { pressure } \\
\text { (CSR assur- } \\
\text { ance } \\
\text { CSR assurer } \\
\text { (audit firm)) }\end{array}$ & $\begin{array}{c}\text { IR adoption } \\
\text { (dummy) }\end{array}$ & $\begin{array}{l}+ \\
\pm\end{array}$ \\
\hline $2013 a$ & $\begin{array}{l}\text { Frias-Acei- } \\
\text { tuno et al }\end{array}$ & $\begin{array}{l}\text { Journal of } \\
\text { Cleaner } \\
\text { Production }\end{array}$ & $\begin{array}{l}\text { International } \\
2129 \text { firm- } \\
\text { year obser- } \\
\text { vations } \\
\text { firms } \\
2008-2010\end{array}$ & $\begin{array}{l}\text { Country- } \\
\text { related } \\
\text { governance } \\
\text { (civil law } \\
\text { Legal } \\
\text { enforcement } \\
\text { (efficiency } \\
\text { of the legal } \\
\text { system, } \\
\text { index of law } \\
\text { and order)) }\end{array}$ & $\begin{array}{l}\text { IR adoption } \\
\text { (dummy) }\end{array}$ & $\begin{array}{l}+ \\
+\end{array}$ \\
\hline
\end{tabular}




\begin{tabular}{|c|c|c|c|c|c|c|}
\hline Year & Author(s) & Reference & $\begin{array}{l}\text { Country } \\
\text { Sample size } \\
\text { Period }\end{array}$ & $\begin{array}{l}\text { Independent } \\
\text { variable(s) }\end{array}$ & $\begin{array}{l}\text { Dependent } \\
\text { variable(s) }\end{array}$ & $\begin{array}{l}\text { Significant } \\
\text { results }\end{array}$ \\
\hline $2013 b$ & $\begin{array}{l}\text { Frias-Acei- } \\
\text { tuno et al }\end{array}$ & $\begin{array}{l}\text { Corporate } \\
\text { Social } \\
\text { Responsi- } \\
\text { bility and } \\
\text { Environ- } \\
\text { mental } \\
\text { Manage- } \\
\text { ment }\end{array}$ & $\begin{array}{l}\text { International } \\
1575 \text { firm- } \\
\text { year obser- } \\
\text { vations } \\
2008-2010\end{array}$ & $\begin{array}{l}\text { Board com- } \\
\text { position } \\
\text { (board size } \\
\text { Board inde- } \\
\text { pendence } \\
\text { Board activity } \\
\text { Board gender } \\
\text { diversity } \\
\text { Board foreign } \\
\text { diversity) }\end{array}$ & $\begin{array}{l}\text { IR adoption } \\
\text { (dummy) }\end{array}$ & $\begin{array}{l}+ \\
\pm \\
\pm \\
+ \\
\pm\end{array}$ \\
\hline 2013 & $\begin{array}{l}\text { Garcia- } \\
\text { Sanchez } \\
\text { et al }\end{array}$ & $\begin{array}{c}\text { International } \\
\text { Business } \\
\text { Review }\end{array}$ & $\begin{array}{l}\text { International } \\
3042 \text { firm- } \\
\text { year obser- } \\
\text { vations } \\
2008-2010\end{array}$ & $\begin{array}{l}\begin{array}{l}\text { Country- } \\
\text { related }\end{array} \\
\text { governance } \\
\text { (culture: } \\
\text { Collec- } \\
\text { tivism; } \\
\text { Feminism; } \\
\text { Toler- } \\
\text { ance of } \\
\text { uncertainty; } \\
\text { Power } \\
\text { distance; } \\
\text { long-term } \\
\text { orientation) }\end{array}$ & $\begin{array}{c}\text { IR adoption } \\
\text { (dummy) }\end{array}$ & $\begin{array}{l}+ \\
\text { (Collectivism; } \\
\quad \text { Feminism) }\end{array}$ \\
\hline
\end{tabular}




\begin{tabular}{|c|c|c|c|c|c|c|}
\hline Year & Author(s) & Reference & $\begin{array}{l}\text { Country } \\
\text { Sample size } \\
\text { Period }\end{array}$ & $\begin{array}{l}\text { Independent } \\
\text { variable(s) }\end{array}$ & $\begin{array}{l}\text { Dependent } \\
\text { variable(s) }\end{array}$ & $\begin{array}{l}\text { Significant } \\
\text { results }\end{array}$ \\
\hline 2012 & $\begin{array}{c}\text { Jensen \& } \\
\text { Berg }\end{array}$ & $\begin{array}{l}\text { Business } \\
\text { Strategy and } \\
\text { the } \\
\text { Environment }\end{array}$ & $\begin{array}{l}\text { International } \\
204 \text { IR com- } \\
\text { panies from } \\
\text { the GRI } \\
\text { Reports } \\
\text { List } \\
2009\end{array}$ & $\begin{array}{l}\text { Country- } \\
\text { related } \\
\text { governance } \\
\text { (civil law } \\
\text { Investor } \\
\text { protection } \\
\text { Employment } \\
\text { protection } \\
\text { Market orien- } \\
\text { tation } \\
\text { Ownership } \\
\text { concentra- } \\
\text { tion } \\
\text { Share of } \\
\text { private } \\
\text { Expendi- } \\
\text { tures } \\
\text { Density of } \\
\text { trade unions } \\
\text { National } \\
\text { corporate } \\
\text { Responsi- } \\
\text { bility } \\
\text { Value of self- } \\
\text { expression } \\
\text { Secular- } \\
\text { rational } \\
\text { value and } \\
\text { Economic } \\
\text { develop- } \\
\text { ment }\end{array}$ & $\begin{array}{c}\text { IR adoption } \\
\text { (dummy) }\end{array}$ & $\begin{array}{l} \pm \\
+ \\
- \\
+ \\
+ \\
+ \\
+ \\
+ \\
+ \\
+\end{array}$ \\
\hline
\end{tabular}

\section{Appendix 2 Archival research on (non) financial performance and reporting as determinants of IR}

\begin{tabular}{lllllll}
\hline Year & Author(s) & Reference & $\begin{array}{l}\text { Country } \\
\text { Sample size } \\
\text { Period }\end{array}$ & $\begin{array}{l}\text { Independent } \\
\text { variable(s) }\end{array}$ & $\begin{array}{l}\text { Dependent } \\
\text { variable(s) }\end{array}$ & $\begin{array}{l}\text { Significant } \\
\text { results }\end{array}$ \\
\hline 2020b & Vitolla et al & $\begin{array}{c}\text { Corporate } \\
\text { Governance }\end{array}$ & $\begin{array}{l}\text { International } \\
87 \text { banks } \\
2017\end{array}$ & $\begin{array}{c}\text { Financial per- } \\
\text { formance } \\
\text { (ROA) } \\
\text { leverage) }\end{array}$ & $\begin{array}{c}\text { IR quality } \\
\text { (score) }\end{array}$ & + \\
\hline
\end{tabular}




\begin{tabular}{|c|c|c|c|c|c|c|}
\hline Year & Author(s) & Reference & $\begin{array}{l}\text { Country } \\
\text { Sample size } \\
\text { Period }\end{array}$ & $\begin{array}{l}\text { Independent } \\
\text { variable(s) }\end{array}$ & $\begin{array}{l}\text { Dependent } \\
\text { variable(s) }\end{array}$ & $\begin{array}{l}\text { Significant } \\
\text { results }\end{array}$ \\
\hline 2019 & Beretta et al & $\begin{array}{l}\text { Journal of } \\
\text { Intellectual } \\
\text { Capital }\end{array}$ & $\begin{array}{l}\text { Europe } \\
102 \text { reports } \\
2011-2016\end{array}$ & $\begin{array}{l}\text { ESG perfor- } \\
\text { mance } \\
\text { Decline of } \\
\text { Financial } \\
\text { perfor- } \\
\text { mance }\end{array}$ & $\begin{array}{l}\text { IR tone (text } \\
\text { analysis) }\end{array}$ & $\begin{array}{l}+ \\
\pm\end{array}$ \\
\hline 2019 & $\begin{array}{l}\text { Gerwanski } \\
\text { et al }\end{array}$ & $\begin{array}{l}\text { Business } \\
\text { Strategy } \\
\text { and the } \\
\text { Environ- } \\
\text { ment }\end{array}$ & $\begin{array}{l}\text { International } \\
359 \text { firm-year } \\
\text { observa- } \\
\text { tions } \\
2013-2016\end{array}$ & $\begin{array}{l}\text { Learning } \\
\text { effects } \\
\text { IR quality } \\
\text { (readability; } \\
\text { index) } \\
\text { Earnings } \\
\text { quality } \\
\text { (accruals) }\end{array}$ & $\begin{array}{l}\text { IR quality } \\
\text { (materiality } \\
\text { score) }\end{array}$ & $\begin{array}{l}+ \\
\pm \\
\pm\end{array}$ \\
\hline 2019 & Fuhrmann & $\begin{array}{l}\text { Meditary } \\
\text { Account- } \\
\text { ancy } \\
\text { Research }\end{array}$ & $\begin{array}{l}\text { International } \\
353 \text { reports } \\
2012-2016\end{array}$ & $\begin{array}{l}\text { Financial per- } \\
\text { formance } \\
(\text { ROA) } \\
\text { Leverage } \\
\text { ESG perfor- } \\
\text { mance }\end{array}$ & $\begin{array}{l}\text { IR adoption } \\
\text { (dummy) }\end{array}$ & $\begin{array}{l} \pm \\
- \\
+(S)\end{array}$ \\
\hline 2019 & Girella et al & $\begin{array}{l}\text { Business } \\
\text { Strategy } \\
\text { and the } \\
\text { Environ- } \\
\text { ment }\end{array}$ & $\begin{array}{l}\text { International } \\
349 \text { firms } \\
2016\end{array}$ & $\begin{array}{l}\text { Financial per- } \\
\text { formance } \\
\text { (ROA, } \\
\text { Market/ } \\
\text { book ratio) } \\
\text { Leverage } \\
\text { Firm effi- } \\
\text { ciency }\end{array}$ & $\begin{array}{l}\text { IR adoption } \\
\text { (dummy) }\end{array}$ & $\begin{array}{l}+ \\
\pm \\
\pm\end{array}$ \\
\hline 2019 & $\begin{array}{l}\text { Graßmann } \\
\text { et al }\end{array}$ & $\begin{array}{l}\text { Sustainability } \\
\text { Accounting, } \\
\text { Manage- } \\
\text { ment and } \\
\text { Policy }\end{array}$ & $\begin{array}{l}\text { International } \\
169 \text { reports } \\
2013-2014\end{array}$ & $\begin{array}{l}\text { ES }(\mathrm{G}) \text { perfor- } \\
\text { mance } \\
\text { Financial per- } \\
\text { formance } \\
\text { (ROA) } \\
\text { leverage } \\
\text { foreign sales } \\
\text { Price volatil- } \\
\text { ity }\end{array}$ & $\begin{array}{l}\text { IR quality } \\
\text { (integrated } \\
\text { thinking; } \\
\text { score) }\end{array}$ & $\begin{array}{l}+ \\
+ \\
+ \\
- \\
\pm\end{array}$ \\
\hline 2019 & $\begin{array}{l}\text { Pavlopoulos } \\
\text { et al }\end{array}$ & $\begin{array}{l}\text { Research in } \\
\text { Interna- } \\
\text { tional Busi- } \\
\text { ness and } \\
\text { Finance }\end{array}$ & $\begin{array}{l}\text { International } \\
82 \text { IR adop- } \\
\text { ters } \\
2011-2015\end{array}$ & $\begin{array}{l}\text { Earnings } \\
\text { quality } \\
\text { (Accruals } \\
\text { and Income } \\
\text { Smoothing) } \\
\text { Moderator: } \\
\text { Mandatory } \\
\text { IR adoption } \\
\text { (dummy) }\end{array}$ & $\begin{array}{l}\text { IR quality } \\
\text { (score) }\end{array}$ & \pm \\
\hline
\end{tabular}




\begin{tabular}{|c|c|c|c|c|c|c|}
\hline Year & Author(s) & Reference & $\begin{array}{l}\text { Country } \\
\text { Sample size } \\
\text { Period }\end{array}$ & $\begin{array}{l}\text { Independent } \\
\text { variable(s) }\end{array}$ & $\begin{array}{l}\text { Dependent } \\
\text { variable(s) }\end{array}$ & $\begin{array}{l}\text { Significant } \\
\text { results }\end{array}$ \\
\hline 2019 & Roman et al & Sustainabiliy & $\begin{array}{l}\text { International } \\
30 \text { firms } \\
2017\end{array}$ & $\begin{array}{l}\text { Financial per- } \\
\text { formance } \\
\text { (Revenues) } \\
\text { Reporting } \\
\text { (transpar- } \\
\text { ency index) }\end{array}$ & $\begin{array}{l}\text { IR qual- } \\
\text { ity (tone; } \\
\text { textual } \\
\text { analysis) } \\
\text { IR quality } \\
\text { (readability; } \\
\text { Gunning } \\
\text { Fog index) }\end{array}$ & $\begin{array}{l}- \\
-\end{array}$ \\
\hline 2019 & Romero et al & $\begin{array}{l}\text { Business } \\
\text { Strategy } \\
\text { and The } \\
\text { Environ- } \\
\text { ment }\end{array}$ & $\begin{array}{l}\text { Spain } \\
68 \text { firms } \\
2013-2015\end{array}$ & $\begin{array}{l}\text { Separate } \\
\text { CSR report } \\
\text { (dummy) } \\
\text { IR adoption } \\
\text { (dummy) } \\
\text { CSR report } \\
\text { within } \\
\text { annual } \\
\text { report } \\
\text { (dummy) }\end{array}$ & $\begin{array}{l}\text { IR quality/ } \\
\text { quantity } \\
\text { (ratio } \\
\text { of CSR } \\
\text { concepts, } \\
\text { type of } \\
\text { disclosure) }\end{array}$ & $\begin{array}{l}+ \\
+\end{array}$ \\
\hline 2019 & Wachira et al & $\begin{array}{l}\text { Social } \\
\text { Respon- } \\
\text { sibility } \\
\text { Journal }\end{array}$ & $\begin{array}{l}\text { South Africa } \\
2014\end{array}$ & $\begin{array}{l}\text { Analyst fol- } \\
\text { lowing } \\
\text { Transpar- } \\
\text { ency score } \\
\text { (rating by } \\
\text { Integrated } \\
\text { Report- } \\
\text { ing and } \\
\text { Assurance } \\
\text { Services) }\end{array}$ & $\begin{array}{l}\text { IR adoption } \\
\text { (dummy) }\end{array}$ & $\begin{array}{l}+ \\
+\end{array}$ \\
\hline 2018 & Ghani et al & $\begin{array}{l}\text { International } \\
\text { Journal of } \\
\text { Manage- } \\
\text { rial and } \\
\text { Financial } \\
\text { Accounting }\end{array}$ & $\begin{array}{l}\text { Malaysia } \\
74 \text { firms } \\
2016\end{array}$ & $\begin{array}{l}\text { Leverage } \\
\text { liquidity }\end{array}$ & $\begin{array}{l}\text { IR quality } \\
\text { (score) }\end{array}$ & $\begin{array}{l} \pm \\
\pm\end{array}$ \\
\hline 2018 & Menicucci & $\begin{array}{l}\text { Journal of } \\
\text { Applied } \\
\text { Accounting } \\
\text { Research }\end{array}$ & $\begin{array}{l}\text { International } \\
282 \text { reports } \\
2011-2015\end{array}$ & $\begin{array}{l}\text { Financial per- } \\
\text { formance } \\
\text { (ROE) } \\
\text { Leverage }\end{array}$ & $\begin{array}{l}\text { IR quantity; } \\
\text { word count- } \\
\text { ing related } \\
\text { to topics) }\end{array}$ & $\begin{array}{l}+ \\
\pm\end{array}$ \\
\hline 2016 & Lai et al & $\begin{array}{l}\text { Business } \\
\text { Strategy } \\
\text { and the } \\
\text { Environment }\end{array}$ & $\begin{array}{l}\text { International } \\
52 \text { IR adop- } \\
\text { ters } \\
2009-2011\end{array}$ & $\begin{array}{l}\text { ESG perfor- } \\
\text { mance } \\
\text { Leverage } \\
\text { Financial per- } \\
\text { formance }\end{array}$ & $\begin{array}{l}\text { IR adoption } \\
\text { (dummy) }\end{array}$ & $\begin{array}{l}+ \\
\pm \\
-\end{array}$ \\
\hline 2015 & Melloni & $\begin{array}{l}\text { Journal of } \\
\text { Intellectual } \\
\text { Capital }\end{array}$ & $\begin{array}{l}\text { International } \\
52 \text { reports } \\
2011-2013\end{array}$ & $\begin{array}{l}\text { Declining } \\
\text { financial } \\
\text { perfor- } \\
\text { mance }\end{array}$ & $\begin{array}{l}\text { IR qual- } \\
\text { ity (tone; } \\
\text { textual } \\
\text { analysis) }\end{array}$ & + \\
\hline
\end{tabular}




\begin{tabular}{|c|c|c|c|c|c|c|}
\hline Year & Author(s) & Reference & $\begin{array}{l}\text { Country } \\
\text { Sample size } \\
\text { Period }\end{array}$ & $\begin{array}{l}\text { Independent } \\
\text { variable(s) }\end{array}$ & $\begin{array}{l}\text { Dependent } \\
\text { variable(s) }\end{array}$ & $\begin{array}{l}\text { Significant } \\
\text { results }\end{array}$ \\
\hline 2014 & $\begin{array}{c}\text { Churet \& } \\
\text { Eccles }\end{array}$ & $\begin{array}{c}\text { Journal of } \\
\text { Applied } \\
\text { Corporate } \\
\text { Finance }\end{array}$ & $\begin{array}{l}\text { International } \\
\text { Firms from } \\
\text { the Robe- } \\
\text { coSAM } \\
\text { database } \\
2011-2012\end{array}$ & $\begin{array}{l}\text { ESG man- } \\
\text { agement } \\
\text { quality } \\
\text { Financial per- } \\
\text { formance } \\
\text { (ROIC) }\end{array}$ & $\begin{array}{l}\text { IR quality } \\
\text { (score) }\end{array}$ & $\begin{array}{l}+ \\
\pm\end{array}$ \\
\hline 2014 & $\begin{array}{r}\text { Frias-Acei- } \\
\text { tuno et al }\end{array}$ & $\begin{array}{l}\text { Business } \\
\text { Strategy } \\
\text { and the } \\
\text { Environment }\end{array}$ & $\begin{array}{l}\text { International } \\
1590 \text { compa- } \\
\text { nies } \\
2008-2010\end{array}$ & $\begin{array}{l}\text { Financial per- } \\
\text { formance } \\
\text { growth }\end{array}$ & $\begin{array}{l}\text { IR adoption } \\
\text { (dummy) }\end{array}$ & $\begin{array}{l}+ \\
\pm\end{array}$ \\
\hline
\end{tabular}

\section{Appendix 3 Archival research on the consequences of IR on firm value}

\begin{tabular}{|c|c|c|c|c|c|c|}
\hline $\begin{array}{l}\text { Year of } \\
\text { publication }\end{array}$ & Author(s) & Sources & $\begin{array}{l}\text { State } \\
\text { Sample } \\
\text { Year(s) }\end{array}$ & $\begin{array}{l}\text { Independent } \\
\text { variable(s) }\end{array}$ & $\begin{array}{l}\text { Dependent } \\
\text { variable(s) }\end{array}$ & $\begin{array}{l}\text { Significant } \\
\text { results }\end{array}$ \\
\hline 2020 & $\begin{array}{l}\text { Adegboye- } \\
\text { gun et al }\end{array}$ & $\begin{array}{l}\text { Cogent } \\
\text { Business } \\
\text { \& Man- } \\
\text { agement }\end{array}$ & $\begin{array}{l}\text { Nigeria } \\
13 \text { Banks } \\
2009-2018\end{array}$ & $\begin{array}{c}\text { IR quality } \\
\text { (Score) }\end{array}$ & $\begin{array}{l}\text { total per- } \\
\text { formance } \\
\text { measures } \\
\text { (profit } \\
\text { after } \\
\text { taxes) }\end{array}$ & $\begin{array}{l} \pm \text { (short } \\
\quad \text { run }) ;+(\text { long } \\
\text { run })\end{array}$ \\
\hline 2020 & $\begin{array}{l}\text { Albitar and } \\
\text { Hussainey }\end{array}$ & $\begin{array}{l}\text { Interna- } \\
\text { tional } \\
\text { Journal of } \\
\text { Account- } \\
\text { ing and } \\
\text { Informa- } \\
\text { tion Man- } \\
\text { agement }\end{array}$ & $\begin{array}{l}\text { UK } \\
1943 \\
\text { firm-year } \\
\text { observa- } \\
\text { tions } \\
\text { 2009-2018 }\end{array}$ & $\begin{array}{l}\text { ESG } \\
\text { reporting } \\
\text { (Bloomb- } \\
\text { erg data- } \\
\text { base) } \\
\text { Moderators: } \\
\text { IR adoption } \\
\text { (dummy; } \\
\text { introduc- } \\
\text { tion 2013) } \\
\text { ownership } \\
\text { concentra- } \\
\text { tion } \\
\text { gender } \\
\text { diversity } \\
\text { board size }\end{array}$ & $\begin{array}{l}\text { total per- } \\
\text { formance } \\
\text { measures } \\
\text { (Tobin's } \\
\text { Q) }\end{array}$ & $\begin{array}{l}+ \\
\text { Moderators: + }\end{array}$ \\
\hline
\end{tabular}




\begin{tabular}{|c|c|c|c|c|c|c|}
\hline $\begin{array}{l}\text { Year of } \\
\text { publication }\end{array}$ & Author(s) & Sources & $\begin{array}{l}\text { State } \\
\text { Sample } \\
\text { Year(s) }\end{array}$ & $\begin{array}{l}\text { Independent } \\
\text { variable(s) }\end{array}$ & $\begin{array}{l}\text { Dependent } \\
\text { variable(s) }\end{array}$ & $\begin{array}{l}\text { Significant } \\
\text { results }\end{array}$ \\
\hline 2020 & Caglio et al & $\begin{array}{l}\text { European } \\
\text { Account- } \\
\text { ing } \\
\text { Review }\end{array}$ & $\begin{array}{l}\text { South } \\
\text { Africa } \\
443 \text { firm- } \\
\text { year } \\
\text { observa- } \\
\text { tions } \\
2011-2016\end{array}$ & $\begin{array}{l}\text { IR quality } \\
\text { (readabil- } \\
\text { ity; Fog, } \\
\text { Flesch) } \\
\text { IR quality } \\
\text { (tone; } \\
\text { textual } \\
\text { analysis) } \\
\text { IR quantity } \\
\text { (word } \\
\text { count) } \\
\text { Moderator: } \\
\text { IR quality } \\
\text { (assur- } \\
\text { ance; } \\
\text { dummy) }\end{array}$ & $\begin{array}{l}\text { total per- } \\
\text { formance } \\
\text { measures } \\
\text { (Tobin's } \\
\text { Q; ESG } \\
\text { perfor- } \\
\text { mance) } \\
\text { Liquidity } \\
\text { (bid-ask- } \\
\text { spread) } \\
\text { Expected } \\
\text { future } \\
\text { cash flows } \\
\text { (analyst } \\
\text { forecast } \\
\text { disper- } \\
\text { sion) }\end{array}$ & $\begin{array}{l}\text { + (IR read. } \\
\text { and Tobin's } \\
\text { Q; IR length } \\
\text { and bid-ask- } \\
\text { spread) } \\
\text { - (IR tone } \\
\text { and analyst } \\
\text { forecast) } \\
\text { Moderator: IR } \\
\text { assurance } \\
\text { compensates } \\
\text { for poor read- } \\
\text { able und tone } \\
\text { biased IR }\end{array}$ \\
\hline 2020 & Dey & $\begin{array}{l}\text { Interna- } \\
\text { tional } \\
\text { Journal of } \\
\text { Disclosure } \\
\text { and Gov- } \\
\text { ernance }\end{array}$ & $\begin{array}{l}\text { Bangladesh } \\
144 \text { firm- } \\
\text { year } \\
\text { observa- } \\
\text { tions } \\
2013-2018\end{array}$ & $\begin{array}{l}\text { IR quality } \\
\text { (score) }\end{array}$ & $\begin{array}{l}\text { Total per- } \\
\text { formance } \\
\text { measures } \\
\text { (Tobin's } \\
\text { Q) } \\
\text { Stock } \\
\text { liquidity } \\
\text { (spread, } \\
\text { total } \\
\text { numbers } \\
\text { of shares } \\
\text { traded for } \\
\text { the period } \\
\text { divided } \\
\text { by the } \\
\text { number of } \\
\text { year-end } \\
\text { outstand- } \\
\text { ing } \\
\text { shares) }\end{array}$ & $\begin{array}{l}+ \\
\pm\end{array}$ \\
\hline 2020 & $\begin{array}{l}\text { Gal \& } \\
\text { Akisik }\end{array}$ & $\begin{array}{l}\text { Corporate } \\
\text { Social } \\
\text { Responsi- } \\
\text { bility and } \\
\text { Environ- } \\
\text { mental } \\
\text { Manage- } \\
\text { ment }\end{array}$ & $\begin{array}{l}\text { North } \\
\text { America } \\
106 \text { reports } \\
\text { in GRI } \\
\text { website } \\
2011-2016\end{array}$ & $\begin{array}{l}\text { IR adoption } \\
\text { (dummy) } \\
\text { Moderators: } \\
\text { effectiveness } \\
\text { of internal } \\
\text { control } \\
\text { system } \\
\text { IR quality } \\
\text { (third } \\
\text { party } \\
\text { assurance, } \\
\text { audit firm, } \\
\text { non-audit } \\
\text { firm) }\end{array}$ & $\begin{array}{l}\text { Total per- } \\
\text { formance } \\
\text { measures } \\
\text { (Market } \\
\text { value of } \\
\text { equity) }\end{array}$ & $\begin{array}{l} \pm \\
\text { Moderators: }+\end{array}$ \\
\hline
\end{tabular}




\begin{tabular}{|c|c|c|c|c|c|c|}
\hline $\begin{array}{l}\text { Year of } \\
\text { publication }\end{array}$ & Author(s) & Sources & $\begin{array}{l}\text { State } \\
\text { Sample } \\
\text { Year(s) }\end{array}$ & $\begin{array}{l}\text { Independent } \\
\text { variable(s) }\end{array}$ & $\begin{array}{l}\text { Dependent } \\
\text { variable(s) }\end{array}$ & $\begin{array}{l}\text { Significant } \\
\text { results }\end{array}$ \\
\hline 2020 & Gerwanski & $\begin{array}{l}\text { Corporate } \\
\text { Social } \\
\text { Responsi- } \\
\text { bility and } \\
\text { Environ- } \\
\text { mental } \\
\text { Manage- } \\
\text { ment }\end{array}$ & $\begin{array}{l}\text { Interna- } \\
\text { tional } \\
\quad \text { (Europe) } \\
2015-17 \\
2196 \\
\text { firm-year } \\
\text { observa- } \\
\text { tions }\end{array}$ & $\begin{array}{l}\text { IR adoption } \\
\text { (dummy) } \\
\text { Moderators: } \\
\text { lower ESG } \\
\text { perfor- } \\
\text { mance, } \\
\text { environ- } \\
\text { mentally } \\
\text { sensitive } \\
\text { industry }\end{array}$ & $\begin{array}{l}\text { Marginal } \\
\text { cost of } \\
\text { debt }\end{array}$ & $\begin{array}{l}\text { Moderators: } \\
\text { more pro- } \\
\text { nounced }\end{array}$ \\
\hline 2020 & Landau et al & $\begin{array}{l}\text { Business } \\
\text { Strategy } \\
\text { and the } \\
\text { Environ- } \\
\text { ment }\end{array}$ & $\begin{array}{l}\text { Europe } \\
\text { 50 STOXX } \\
\text { Europe } \\
\text { firms } \\
2010-2016\end{array}$ & $\begin{array}{l}\text { IR adoption } \\
\text { (dummy) } \\
\text { in com- } \\
\text { parison to } \\
\text { separate } \\
\text { ESG } \\
\text { report } \\
\text { Moderator: } \\
\text { IR quality } \\
\text { (assurance } \\
\text { by big } \\
\text { four); IR } \\
\text { according } \\
\text { to GRI }\end{array}$ & $\begin{array}{l}\text { total per- } \\
\text { formance } \\
\text { measures } \\
\text { (market } \\
\text { value of } \\
\text { equity) }\end{array}$ & Moderator: \pm \\
\hline 2020 & $\begin{array}{r}\text { Moloi \& } \\
\text { Iredele }\end{array}$ & $\begin{array}{l}\text { Academy of } \\
\text { Strategic } \\
\text { Manage- } \\
\text { ment } \\
\text { Journal }\end{array}$ & $\begin{array}{l}\text { South } \\
\text { Africa } \\
20 \text { firms } \\
2013-2017\end{array}$ & $\begin{array}{l}\text { IR quality } \\
\text { (EY } \\
\text { awards) }\end{array}$ & $\begin{array}{l}\text { total per- } \\
\text { formance } \\
\text { measures } \\
\text { (Tobin's } \\
\text { Q) }\end{array}$ & + \\
\hline 2020 & $\begin{array}{l}\text { Muttakin } \\
\text { et al }\end{array}$ & $\begin{array}{l}\text { Interna- } \\
\text { tional } \\
\text { Journal of } \\
\text { Account- } \\
\text { ing \& } \\
\text { Informa- } \\
\text { tion Man- } \\
\text { agement }\end{array}$ & $\begin{array}{l}\text { South } \\
\text { Africa } \\
847 \text { firm- } \\
\text { year } \\
\text { observa- } \\
\text { tions } \\
\text { 2009-2015 }\end{array}$ & $\begin{array}{l}\text { IR adoption } \\
\text { (dummy) } \\
\text { Earnings } \\
\text { quality } \\
\text { Moderator: } \\
\text { IR adop- } \\
\text { tion }\end{array}$ & $\begin{array}{l}\text { Cost of } \\
\text { capital } \\
\text { (Cost of } \\
\text { debt) }\end{array}$ & $\begin{array}{l}- \\
- \\
\text { Moderator: } \\
\text { more pro- } \\
\text { nounced }\end{array}$ \\
\hline $2020 \mathrm{a}$ & Obeng et al & $\begin{array}{l}\text { Pacific- } \\
\text { Basin } \\
\text { Finance } \\
\text { Journal }\end{array}$ & $\begin{array}{l}\text { Interna- } \\
\text { tional } \\
\text { (without } \\
\text { South } \\
\text { Africa) } \\
4420 \\
\text { firm-year } \\
\text { observa- } \\
\text { tions } \\
\text { 2009-2015 }\end{array}$ & $\begin{array}{l}\text { IR adoption } \\
\text { (Dummy) } \\
\text { IR quality } \\
\text { (scoring) } \\
\text { Moderator: } \\
\text { agency } \\
\text { costs } \\
\text { (cash flow, } \\
\text { expense } \\
\text { ratio, } \\
\text { dividend } \\
\text { payout, } \\
\text { asset utili- } \\
\text { sation) }\end{array}$ & $\begin{array}{l}\text { Earnings } \\
\text { quality } \\
\text { (earnings } \\
\text { manage- } \\
\text { ment } \\
\text { score: } \\
\text { accruals, } \\
\text { income } \\
\text { smooth- } \\
\text { ing, } \\
\text { earnings } \\
\text { persis- } \\
\text { tence) }\end{array}$ & $\begin{array}{l}+ \\
+ \\
\text { Modera- } \\
\text { tor: + (adop- } \\
\text { tion); } \pm \text { (qual- } \\
\text { ity) }\end{array}$ \\
\hline
\end{tabular}




\begin{tabular}{|c|c|c|c|c|c|c|}
\hline $\begin{array}{l}\text { Year of } \\
\text { publication }\end{array}$ & Author(s) & Sources & $\begin{array}{l}\text { State } \\
\text { Sample } \\
\text { Year(s) }\end{array}$ & $\begin{array}{l}\text { Independent } \\
\text { variable(s) }\end{array}$ & $\begin{array}{l}\text { Dependent } \\
\text { variable(s) }\end{array}$ & $\begin{array}{l}\text { Significant } \\
\text { results }\end{array}$ \\
\hline $2020 b$ & Obeng et al & $\begin{array}{l}\text { European } \\
\text { Account- } \\
\text { ing } \\
\text { Review }\end{array}$ & $\begin{array}{l}\text { Interna- } \\
\text { tional } \\
\text { (without } \\
\text { South } \\
\text { Africa) } \\
\text { 2009-2017 } \\
806 \text { firms }\end{array}$ & $\begin{array}{l}\text { IR quality } \\
\text { (score) } \\
\text { Moderator: } \\
\text { code law } \\
\text { regime; } \\
\text { diversified } \\
\text { firms }\end{array}$ & $\begin{array}{l}\text { Agency } \\
\text { costs (free } \\
\text { cash flow } \\
\text { * growth; } \\
\text { expense } \\
\text { ratio, } \\
\text { dividend } \\
\text { payout } \\
\text { ratio; } \\
\text { expense } \\
\text { ratio and } \\
\text { asset utili- } \\
\text { zation) }\end{array}$ & $\begin{array}{l}\text { Moderators: } \\
\text { more pro- } \\
\text { nounced }\end{array}$ \\
\hline 2020 & Omran et al & $\begin{array}{l}\text { Corporate } \\
\text { Social } \\
\text { Responsi- } \\
\text { bility and } \\
\text { Environ- } \\
\text { mental } \\
\text { Manage- } \\
\text { ment }\end{array}$ & $\begin{array}{l}\text { South } \\
\text { Africa } \\
110 \text { firms } \\
2014-18\end{array}$ & $\begin{array}{l}\text { IR quality } \\
\text { (score; EY } \\
\text { ranking) }\end{array}$ & $\begin{array}{l}\text { Total per- } \\
\text { formance } \\
\text { measures } \\
\text { (environ- } \\
\text { mental } \\
\text { perfor- } \\
\text { mance; } \\
\text { Asset- } \\
\text { Four) }\end{array}$ & + \\
\hline 2020 & $\begin{array}{c}\text { Sriani and } \\
\text { Augstia }\end{array}$ & Heliyon & $\begin{array}{l}\text { Interna- } \\
\text { tional } \\
\text { (Europe } \\
\text { and Asia) } \\
94 \text { firms } \\
2016\end{array}$ & $\begin{array}{l}\text { IR quality } \\
\text { (score) } \\
\text { Moderator: } \\
\text { firm size }\end{array}$ & $\begin{array}{l}\text { Stock } \\
\text { liquidity } \\
\text { (spread) }\end{array}$ & $\begin{array}{l} \pm \\
\text { Moderator: } \pm\end{array}$ \\
\hline 2020 & Vena et al & $\begin{array}{l}\text { Journal of } \\
\text { Interna- } \\
\text { tional } \\
\text { Financial } \\
\text { Manage- } \\
\text { ment \& } \\
\text { Account- } \\
\text { ing }\end{array}$ & $\begin{array}{l}\text { Interna- } \\
\text { tional } \\
211 \text { firms } \\
2009-2017\end{array}$ & $\begin{array}{l}\text { IR adoption } \\
\text { (Dummy) } \\
\text { Moderator: } \\
\text { culture } \\
\text { (power } \\
\text { distance, } \\
\text { collev- } \\
\text { tivism, } \\
\text { masculin- } \\
\text { ity, uncer- } \\
\text { tainty } \\
\text { avoidance, } \\
\text { long-term } \\
\text { orienta- } \\
\text { tion, } \\
\text { indul- } \\
\text { gence) }\end{array}$ & $\begin{array}{l}\text { Cost of } \\
\text { capital } \\
\text { (WACC) }\end{array}$ & $\begin{array}{l}\text { Modera- } \\
\text { tor: more } \\
\text { pronounced } \\
\text { by low power } \\
\text { distance, } \\
\text { strong colle- } \\
\text { vitism values, } \\
\text { and high } \\
\text { masculinity }\end{array}$ \\
\hline
\end{tabular}




\begin{tabular}{|c|c|c|c|c|c|c|}
\hline $\begin{array}{l}\text { Year of } \\
\text { publication }\end{array}$ & Author(s) & Sources & $\begin{array}{l}\text { State } \\
\text { Sample } \\
\text { Year(s) }\end{array}$ & $\begin{array}{l}\text { Independent } \\
\text { variable(s) }\end{array}$ & $\begin{array}{l}\text { Dependent } \\
\text { variable(s) }\end{array}$ & $\begin{array}{l}\text { Significant } \\
\text { results }\end{array}$ \\
\hline $2020 \mathrm{c}$ & Vitolla et al & $\begin{array}{l}\text { Business } \\
\text { Strategy } \\
\text { and the } \\
\text { Environ- } \\
\text { ment }\end{array}$ & $\begin{array}{l}\text { Interna- } \\
\quad \text { tional } \\
116 \text { firms } \\
2016\end{array}$ & $\begin{array}{l}\text { IR quality } \\
\text { (score) }\end{array}$ & $\begin{array}{l}\text { Cost of } \\
\text { capital } \\
\text { (cost of } \\
\text { equity; } \\
\text { PEG ratio } \\
\text { method } \\
\text { by Easton } \\
\text { 2004) }\end{array}$ & - \\
\hline 2020 & Wahl et al & $\begin{array}{l}\text { Business } \\
\text { Strategy } \\
\text { and the } \\
\text { Environ- } \\
\text { ment }\end{array}$ & $\begin{array}{l}\text { Interna- } \\
\text { tional } \\
167 \text { firms } \\
2011-2018\end{array}$ & $\begin{array}{l}\text { IR adoption } \\
\text { (dummy) }\end{array}$ & $\begin{array}{l}\text { Expected } \\
\text { future } \\
\text { cash flows } \\
\text { (analyst } \\
\text { forecast } \\
\text { accuracy) } \\
\text { Total per- } \\
\text { formance } \\
\text { measures } \\
\text { (Tobin's } \\
\text { Q) }\end{array}$ & $\begin{array}{l} \pm \\
\pm\end{array}$ \\
\hline 2020 & Zuniga et al & $\begin{array}{c}\text { Accounting } \\
\text { Research } \\
\text { Journal }\end{array}$ & $\begin{array}{l}\text { South } \\
\text { Africa } \\
297 \text { firm- } \\
\text { year } \\
\text { observa- } \\
\text { tions } \\
2013-2015\end{array}$ & $\begin{array}{l}\text { IR quality } \\
\text { (score) } \\
\text { Moderator: } \\
\text { material } \\
\text { sector; } \\
\text { firms with } \\
\text { volatile } \\
\text { returns, } \\
\text { firm size }\end{array}$ & $\begin{array}{l}\text { Stock } \\
\text { liquidity } \\
\text { (bid-ask- } \\
\text { spread) } \\
\text { Expected } \\
\text { future } \\
\text { cash flows } \\
\text { (analyst } \\
\text { forecast } \\
\text { error) }\end{array}$ & $\begin{array}{l}+ \\
- \\
\text { Moderators: } \\
\text { lower for } \\
\text { large firms } \\
\text { and higher } \\
\text { for firms } \\
\text { with volatile } \\
\text { returns }\end{array}$ \\
\hline 2019 & $\begin{array}{l}\text { Akisik \& } \\
\text { Gal }\end{array}$ & $\begin{array}{l}\text { Sustain- } \\
\text { ability } \\
\text { Account- } \\
\text { ing, Man- } \\
\text { agement } \\
\text { and Policy } \\
\text { Journal }\end{array}$ & $\begin{array}{l}\text { North } \\
\text { America } \\
106 \text { reports } \\
\text { in GRI } \\
\text { website } \\
2011-2016\end{array}$ & $\begin{array}{l}\text { IR adoption } \\
\text { (dummy) } \\
\text { Moderator: } \\
\text { IR quality } \\
\text { (assurance } \\
\text { by audit } \\
\text { firm) }\end{array}$ & $\begin{array}{l}\text { total per- } \\
\text { formance } \\
\text { measures } \\
\text { (stock } \\
\text { price } \\
\text { growth, } \\
\text { ROE, } \\
\text { ROA) }\end{array}$ & $\begin{array}{l}+ \\
\text { Moderator: }+\end{array}$ \\
\hline 2019 & Conway & $\begin{array}{l}\text { Journal of } \\
\text { Financial } \\
\text { Report- } \\
\text { ing and } \\
\text { Account- } \\
\text { ing }\end{array}$ & $\begin{array}{l}\text { South } \\
\text { Africa } \\
2006-2015\end{array}$ & $\begin{array}{l}\text { IR adoption } \\
\text { (dummy) } \\
\text { IR quality }\end{array}$ & $\begin{array}{l}\text { Total per- } \\
\text { formance } \\
\text { measures } \\
\text { (financial } \\
\text { perfor- } \\
\text { mance, } \\
\text { risk, ESG } \\
\text { perfor- } \\
\text { mance) }\end{array}$ & $\begin{array}{l}\text { - (IR adoption; } \\
\text { IR quality)) } \\
\text { _ (IR adoption; } \\
\text { IR quality)) } \\
\text { + (IR quality) }\end{array}$ \\
\hline
\end{tabular}




\begin{tabular}{|c|c|c|c|c|c|c|}
\hline $\begin{array}{l}\text { Year of } \\
\text { publication }\end{array}$ & Author(s) & Sources & $\begin{array}{l}\text { State } \\
\text { Sample } \\
\text { Year(s) }\end{array}$ & $\begin{array}{l}\text { Independent } \\
\text { variable(s) }\end{array}$ & $\begin{array}{l}\text { Dependent } \\
\text { variable(s) }\end{array}$ & $\begin{array}{l}\text { Significant } \\
\text { results }\end{array}$ \\
\hline 2019 & $\begin{array}{l}\text { Cortesi \& } \\
\text { Vena }\end{array}$ & $\begin{array}{l}\text { Journal of } \\
\text { Cleaner } \\
\text { Produc- } \\
\text { tion }\end{array}$ & $\begin{array}{l}\text { Interna- } \\
\text { tional } \\
636 \text { firms } \\
2003-2017\end{array}$ & $\begin{array}{l}\text { IR adoption } \\
\text { (dummy) } \\
\text { Moderators: } \\
\text { geographi- } \\
\text { cal prov- } \\
\text { enance } \\
\text { countries' } \\
\text { economic } \\
\text { structure } \\
\text { legal system }\end{array}$ & $\begin{array}{l}\text { Total per- } \\
\text { formance } \\
\text { measures } \\
\text { (Market } \\
\text { value of } \\
\text { equity) }\end{array}$ & $\begin{array}{l}+ \\
\text { Moderators: } \pm\end{array}$ \\
\hline 2019 & Flores et al & $\begin{array}{l}\text { Business } \\
\text { Strategy } \\
\text { and the } \\
\text { Environ- } \\
\text { ment }\end{array}$ & $\begin{array}{l}\text { Interna- } \\
\text { tional } \\
2,496 \\
\text { firm-year } \\
\text { observa- } \\
\text { tions } \\
\text { 2009-2016 }\end{array}$ & $\begin{array}{l}\text { IR adoption } \\
\text { (dummy) } \\
\text { Moderator: } \\
\text { North } \\
\text { American } \\
\text { (share- } \\
\text { holder) } \\
\text { regime } \\
\text { versus } \\
\text { Europe } \\
\text { (stake- } \\
\text { holder) }\end{array}$ & $\begin{array}{l}\text { Expected } \\
\text { future } \\
\text { cash flows } \\
\text { (analyst } \\
\text { forecast } \\
\text { accuracy } \\
\text { Analyst } \\
\text { coverage) }\end{array}$ & $\begin{array}{l}+ \\
\text { Modera- } \\
\text { tor: more } \\
\text { pronounced } \\
\text { in North } \\
\text { America than } \\
\text { in Europe } \\
+\end{array}$ \\
\hline 2019 & Lemma et al & $\begin{array}{l}\text { Asian } \\
\text { Review of } \\
\text { Account- } \\
\text { ing }\end{array}$ & $\begin{array}{l}\text { South } \\
\text { Africa } \\
832 \text { firm- } \\
\text { year } \\
\text { observa- } \\
\text { tions } \\
\text { 2009-2015 }\end{array}$ & $\begin{array}{l}\text { IR adoption } \\
\text { (dummy) } \\
\text { Mediator: } \\
\text { earnings } \\
\text { quality }\end{array}$ & $\begin{array}{l}\text { Total per- } \\
\text { formance } \\
\text { measures } \\
\text { (Leverage) }\end{array}$ & Mediator: + \\
\hline 2019 & $\begin{array}{l}\text { Loprevite } \\
\text { et al }\end{array}$ & $\begin{array}{l}\text { Interna- } \\
\text { tional } \\
\text { Journal of } \\
\text { Manage- } \\
\text { rial and } \\
\text { Financial } \\
\text { Account- } \\
\text { ing }\end{array}$ & $\begin{array}{l}\text { Europe } \\
151 \text { firms } \\
2014-2017\end{array}$ & $\begin{array}{l}\text { IR adoption } \\
\text { (dummy) }\end{array}$ & $\begin{array}{l}\text { Total per- } \\
\text { formance } \\
\text { measures } \\
\text { (Market } \\
\text { value of } \\
\text { equity) }\end{array}$ & \pm \\
\hline 2019 & $\begin{array}{l}\text { Pavlopoulos } \\
\text { et al }\end{array}$ & $\begin{array}{l}\text { Research in } \\
\text { Interna- } \\
\text { tional } \\
\text { Busi- } \\
\text { ness and } \\
\text { Finance }\end{array}$ & $\begin{array}{l}\text { Interna- } \\
\text { tional } \\
82 \text { IR adop- } \\
\text { ters } \\
2011-2015\end{array}$ & $\begin{array}{l}\text { IR quality } \\
\text { (score) }\end{array}$ & $\begin{array}{l}\begin{array}{c}\text { Total per- } \\
\text { formance } \\
\text { measures }\end{array} \\
\text { (ROA, } \\
\text { Market } \\
\text { value of } \\
\text { equity, } \\
\text { CAR) }\end{array}$ & $\begin{array}{l}+ \\
+ \\
+\end{array}$ \\
\hline
\end{tabular}




\begin{tabular}{|c|c|c|c|c|c|c|}
\hline $\begin{array}{l}\text { Year of } \\
\text { publication }\end{array}$ & Author(s) & Sources & $\begin{array}{l}\text { State } \\
\text { Sample } \\
\text { Year(s) }\end{array}$ & $\begin{array}{l}\text { Independent } \\
\text { variable(s) }\end{array}$ & $\begin{array}{l}\text { Dependent } \\
\text { variable(s) }\end{array}$ & $\begin{array}{l}\text { Significant } \\
\text { results }\end{array}$ \\
\hline 2019 & Tlili et al & $\begin{array}{l}\text { Journal of } \\
\text { Intel- } \\
\text { lectual } \\
\text { Capital }\end{array}$ & $\begin{array}{l}\text { South } \\
\text { Africa } \\
99 \text { firms } \\
2006-2015\end{array}$ & $\begin{array}{l}\text { IR adoption } \\
\text { (dummy) }\end{array}$ & $\begin{array}{l}\text { Total per- } \\
\text { formance } \\
\text { measures } \\
\text { (value } \\
\text { relevance } \\
\text { of organi- } \\
\text { zational } \\
\text { capital) }\end{array}$ & + \\
\hline 2018 & $\begin{array}{l}\text { Bernardi \& } \\
\text { Stark }\end{array}$ & $\begin{array}{l}\text { The British } \\
\text { Account- } \\
\text { ing } \\
\text { Review }\end{array}$ & $\begin{array}{l}\text { South } \\
\text { Africa } \\
205 \text { obser- } \\
\text { vations } \\
2008-2012\end{array}$ & $\begin{array}{l}\text { IR adoption } \\
\text { (Dummy) } \\
\text { Mediator: } \\
\text { ESG per- } \\
\text { formance } \\
\text { (rating by } \\
\text { Bloomb- } \\
\text { erg) }\end{array}$ & $\begin{array}{l}\text { Expected } \\
\text { future } \\
\text { cash flows } \\
\text { (analyst } \\
\text { forecast } \\
\text { error) }\end{array}$ & $\begin{array}{l}\text { - (especially } \\
\text { environmental } \\
\text { ratings) }\end{array}$ \\
\hline 2018 & $\begin{array}{l}\text { Camodeca } \\
\text { et al }\end{array}$ & $\begin{array}{r}\text { Sustain- } \\
\text { ability }\end{array}$ & $\begin{array}{l}\text { Interna- } \\
\text { tional } \\
\text { (Europe) } \\
32 \text { IR adop- } \\
\text { ters } \\
2013-2018\end{array}$ & $\begin{array}{l}\text { IR quality } \\
\text { (tone; } \\
\text { textual } \\
\text { analysis) }\end{array}$ & $\begin{array}{l}\text { Total per- } \\
\text { formance } \\
\text { measures } \\
\text { (Market } \\
\text { value of } \\
\text { equity) }\end{array}$ & \pm \\
\hline 2018 & Cosma et al & $\begin{array}{l}\text { African } \\
\text { Journal of } \\
\text { Business } \\
\text { Manage- } \\
\text { ment }\end{array}$ & $\begin{array}{l}\text { South } \\
\text { Africa } \\
76 \text { observa- } \\
\text { tions } \\
\text { 2013-2016 }\end{array}$ & $\begin{array}{l}\text { IR quality } \\
\text { (awards) } \\
\text { Moderator: } \\
\text { industry }\end{array}$ & $\begin{array}{l}\text { Total per- } \\
\text { formance } \\
\text { measures } \\
\text { (Cumu- } \\
\text { lative } \\
\text { abnormal } \\
\text { returns) }\end{array}$ & $\begin{array}{l}+ \\
\text { Moderator: } \pm\end{array}$ \\
\hline 2018 & $\begin{array}{l}\text { Loprevite } \\
\text { et al }\end{array}$ & $\begin{array}{l}\text { Sustain- } \\
\text { ability }\end{array}$ & $\begin{array}{l}\text { Interna- } \\
\text { tional } \\
\text { (Europe } \\
\text { versus } \\
\text { South } \\
\text { Africa) } \\
2,380 \\
\text { firm-year } \\
\text { observa- } \\
\text { tions } \\
\text { 2012-2016 }\end{array}$ & $\begin{array}{l}\text { IR adoption } \\
\text { (dummy; } \\
\text { mandatory } \\
\text { versus } \\
\text { voluntary } \\
\text { versus no) } \\
\text { ESG perfor- } \\
\text { mance } \\
\text { Moderator: } \\
\text { volun- } \\
\text { tary IR } \\
\text { adoption } \\
\text { (dummy) }\end{array}$ & $\begin{array}{l}\text { Total per- } \\
\text { formance } \\
\text { measures } \\
\text { (ESG per- } \\
\text { formance, } \\
\text { Market } \\
\text { value of } \\
\text { equity) }\end{array}$ & $\begin{array}{l}+ \text { (voluntary; } \\
\text { mandatory in } \\
\text { the medium } \\
\text { term }) \\
+(\text { also + mod- } \\
\text { erator })\end{array}$ \\
\hline 2019 & $\begin{array}{l}\text { Loprevite } \\
\text { et al }\end{array}$ & $\begin{array}{l}\text { Interna- } \\
\text { tional } \\
\text { Journal of } \\
\text { Business } \\
\text { and Man- } \\
\text { agement }\end{array}$ & $\begin{array}{l}\text { Interna- } \\
\text { tional } \\
\quad \text { (Europe) } \\
88 \text { firms } \\
2014-2015\end{array}$ & $\begin{array}{l}\text { IR adoption } \\
\text { (dummy) }\end{array}$ & $\begin{array}{l}\text { Total per- } \\
\text { formance } \\
\text { measures } \\
\text { (value rel- } \\
\text { evance of } \\
\text { earnings) }\end{array}$ & + \\
\hline
\end{tabular}




\begin{tabular}{|c|c|c|c|c|c|c|}
\hline $\begin{array}{l}\text { Year of } \\
\text { publication }\end{array}$ & Author(s) & Sources & $\begin{array}{l}\text { State } \\
\text { Sample } \\
\text { Year(s) }\end{array}$ & $\begin{array}{l}\text { Independent } \\
\text { variable(s) }\end{array}$ & $\begin{array}{l}\text { Dependent } \\
\text { variable(s) }\end{array}$ & $\begin{array}{l}\text { Significant } \\
\text { results }\end{array}$ \\
\hline 2017 & Barth et al & $\begin{array}{c}\text { Accounting, } \\
\text { Organiza- } \\
\text { tions and } \\
\text { Society }\end{array}$ & $\begin{array}{l}\text { South } \\
\text { Africa } \\
292,221, \\
189 \\
2011-2014\end{array}$ & $\begin{array}{c}\text { IR quality } \\
\text { (EY } \\
\text { awards) }\end{array}$ & $\begin{array}{l}\text { Expected } \\
\text { future } \\
\text { cash flows } \\
\text { (analyst } \\
\text { forecast } \\
\text { error) } \\
\text { Cost of } \\
\text { equity } \\
\text { (mean of } \\
\text { the cost } \\
\text { meas- } \\
\text { ures by } \\
\text { Claus and } \\
\text { Thomas, } \\
\text { Gebhardt } \\
\text { et al., Ohl- } \\
\text { son and } \\
\text { Juettner- } \\
\text { Nauroth } \\
\text { and } \\
\text { Easton) } \\
\text { Liquidity } \\
\text { (Bid-ask- } \\
\text { spread) } \\
\text { Expected } \\
\text { future } \\
\text { cash flow } \\
\text { (stock } \\
\text { price fore- } \\
\text { casted by } \\
\text { financial } \\
\text { analysts) } \\
\text { Realized } \\
\text { future } \\
\text { cash flow } \\
\text { from } \\
\text { operating } \\
\text { activities } \\
\text { (invest- } \\
\text { ment } \\
\text { efficiency) } \\
\text { Tobin's Q }\end{array}$ & $\begin{array}{l} \pm \\
\pm \\
+ \\
+ \\
+ \\
+\end{array}$ \\
\hline
\end{tabular}




\begin{tabular}{|c|c|c|c|c|c|c|}
\hline $\begin{array}{l}\text { Year of } \\
\text { publication }\end{array}$ & Author(s) & Sources & $\begin{array}{l}\text { State } \\
\text { Sample } \\
\text { Year(s) }\end{array}$ & $\begin{array}{l}\text { Independent } \\
\text { variable(s) }\end{array}$ & $\begin{array}{l}\text { Dependent } \\
\text { variable(s) }\end{array}$ & $\begin{array}{l}\text { Significant } \\
\text { results }\end{array}$ \\
\hline $2017 \mathrm{a}$ & $\begin{array}{l}\text { Garcia- } \\
\text { Sanchez \& } \\
\text { Noguera- } \\
\text { Gamez }\end{array}$ & $\begin{array}{l}\text { Corporate } \\
\text { Social } \\
\text { Responsi- } \\
\text { bility and } \\
\text { Environ- } \\
\text { mental } \\
\text { Manage- } \\
\text { ment }\end{array}$ & $\begin{array}{l}\text { Interna- } \\
\text { tional } \\
995 \text { firms } \\
2009-2013\end{array}$ & $\begin{array}{l}\text { IR adoption } \\
\text { (dummy) } \\
\text { Moderators: } \\
\text { earnings } \\
\text { quality } \\
\text { (accruals) } \\
\text { investor } \\
\text { protection } \\
\text { (common } \\
\text { law; anti- } \\
\text { director } \\
\text { rights; } \\
\text { index of } \\
\text { judicial } \\
\text { efficiency } \\
\text { and index } \\
\text { of law and } \\
\text { order) }\end{array}$ & $\begin{array}{l}\text { Expected } \\
\text { future } \\
\text { cash flows } \\
\text { (analyst } \\
\text { forecast } \\
\text { error) }\end{array}$ & Moderators: + \\
\hline $2017 b$ & $\begin{array}{l}\text { Garcia- } \\
\text { Sanchez \& } \\
\text { Noguera- } \\
\text { Gamez }\end{array}$ & $\begin{array}{l}\text { Interna- } \\
\text { tional } \\
\text { Business } \\
\text { Review }\end{array}$ & $\begin{array}{l}\text { Interna- } \\
\text { tional } \\
3,294 \\
\text { observa- } \\
\text { tions } \\
2009-2013\end{array}$ & $\begin{array}{l}\text { IR adoption } \\
\text { (dummy) }\end{array}$ & $\begin{array}{l}\text { Cost of } \\
\text { equity } \\
\text { (PEG } \\
\text { model by } \\
\text { Easton } \\
2004\end{array}$ & - \\
\hline 2017 & Maniora & $\begin{array}{l}\text { Journal of } \\
\text { Business } \\
\text { Ethics }\end{array}$ & $\begin{array}{l}\text { Interna- } \\
\text { tional } \\
250-280 \\
\text { compa- } \\
\text { nies } \\
2002-2011\end{array}$ & $\begin{array}{l}\text { IR adoption } \\
\text { (dummy) }\end{array}$ & $\begin{array}{l}\text { Total per- } \\
\text { formance } \\
\text { measures } \\
\text { (ESG } \\
\text { integration } \\
\text { (integrated } \\
\text { thinking, } \\
\text { integrated } \\
\text { manage- } \\
\text { ment and } \\
\text { overall } \\
\text { integration } \\
\text { level) } \\
\text { ESG perfor- } \\
\text { mance) }\end{array}$ & $\begin{array}{l}\text { (+) only com- } \\
\text { pared with no } \\
\text { ESG reporters } \\
\text { and ESG } \\
\text { reporting in } \\
\text { annual reports } \\
\text { (-) compared } \\
\text { with stand- } \\
\text { alone ESG } \\
\text { reports }\end{array}$ \\
\hline 2017 & $\begin{array}{l}\text { Mervel- } \\
\text { skemper } \\
\& \\
\text { Streit }\end{array}$ & $\begin{array}{l}\text { Business } \\
\text { Strategy } \\
\text { and the } \\
\text { Environ- } \\
\text { ment }\end{array}$ & $\begin{array}{l}\text { Interna- } \\
\text { tional } \\
215 \text { firms } \\
2009-2014\end{array}$ & $\begin{array}{l}\text { ESG per- } \\
\text { formance } \\
\text { (Asset } \\
\text { four) } \\
\text { Moderator: } \\
\text { IR adop- } \\
\text { tion }\end{array}$ & $\begin{array}{l}\text { Total per- } \\
\text { formance } \\
\text { measures } \\
\text { (Market } \\
\text { value of } \\
\text { equity) }\end{array}$ & $\begin{array}{l}\text { ESG perfor- } \\
\text { mance gets } \\
\text { valued more } \\
\text { strongly and } \\
\text { in the positive } \\
\text { direction } \\
\text { when a firm } \\
\text { publishes an } \\
\text { ESG report, } \\
\text { irrespective of } \\
\text { its type } \\
\text { Moderator: } \pm\end{array}$ \\
\hline
\end{tabular}




\begin{tabular}{|c|c|c|c|c|c|c|}
\hline $\begin{array}{l}\text { Year of } \\
\text { publication }\end{array}$ & Author(s) & Sources & $\begin{array}{l}\text { State } \\
\text { Sample } \\
\text { Year(s) }\end{array}$ & $\begin{array}{l}\text { Independent } \\
\text { variable(s) }\end{array}$ & $\begin{array}{l}\text { Dependent } \\
\text { variable(s) }\end{array}$ & $\begin{array}{l}\text { Significant } \\
\text { results }\end{array}$ \\
\hline 2017 & $\begin{array}{l}\text { Oshika \& } \\
\text { Saka }\end{array}$ & $\begin{array}{l}\text { Social } \\
\text { Respon- } \\
\text { sibility } \\
\text { Journal }\end{array}$ & $\begin{array}{l}\text { Interna- } \\
\text { tional } \\
12,345 \\
\text { firms } \\
2012\end{array}$ & $\begin{array}{l}\text { IR adoption } \\
\text { (dummy) }\end{array}$ & $\begin{array}{l}\text { Distribu- } \\
\text { tions to } \\
\text { stake- } \\
\text { holders } \\
\text { (employ- } \\
\text { ees, } \\
\text { creditors, } \\
\text { govern- } \\
\text { ment and } \\
\text { sharehold- } \\
\text { ers) } \\
\text { Total per- } \\
\text { formance } \\
\text { measures } \\
\text { (gross } \\
\text { margin, } \\
\text { EBIT } \\
\text { ratio, net } \\
\text { income } \\
\text { ratio, ROE } \\
\text { and ROA) }\end{array}$ & $\begin{array}{l}+ \\
+\end{array}$ \\
\hline 2017 & $\begin{array}{l}\text { Pavlopoulos } \\
\text { et al }\end{array}$ & $\begin{array}{l}\text { Journal of } \\
\text { Multi- } \\
\text { national } \\
\text { Financial } \\
\text { Manage- } \\
\text { ment }\end{array}$ & $\begin{array}{l}\text { Interna- } \\
\text { tional } \\
82 \text { firms } \\
2011-2015\end{array}$ & $\begin{array}{l}\text { IR quality } \\
\text { (disclosure } \\
\text { index) }\end{array}$ & $\begin{array}{l}\text { Agency } \\
\text { costs } \\
\text { (Tobin's } \\
\text { Q * cash } \\
\text { flows) }\end{array}$ & - \\
\hline 2017 & Zhou et al & Abacus & $\begin{array}{l}\text { South } \\
\text { Africa } \\
443 \text { obser- } \\
\text { vations } \\
\text { 2009-2012 }\end{array}$ & $\begin{array}{l}\text { IR quality } \\
\text { (score) } \\
\text { Moderator: } \\
\text { analyst } \\
\text { following }\end{array}$ & $\begin{array}{l}\text { Expected } \\
\text { future } \\
\text { cash flows } \\
\text { (analyst } \\
\text { forecast } \\
\text { disper- } \\
\text { sion/error) } \\
\text { Cost of } \\
\text { equity } \\
\text { (PEG } \\
\text { model by } \\
\text { Easton } \\
2004\end{array}$ & $\begin{array}{l}- \\
\text { - } \\
\text { Moderator: } \\
\text { more pro- } \\
\text { nounced with } \\
\text { a low analyst } \\
\text { following }\end{array}$ \\
\hline 2016 & $\begin{array}{l}\text { Babouk- } \\
\text { ardos \& } \\
\text { Rimmel }\end{array}$ & $\begin{array}{l}\text { Journal of } \\
\text { Account- } \\
\text { ing and } \\
\text { Public } \\
\text { Policy }\end{array}$ & $\begin{array}{l}\text { South } \\
\text { Africa } \\
954 \text { firm- } \\
\text { year } \\
\text { observa- } \\
\text { tions } \\
2008-2010 \\
\text { and } \\
2011- \\
2013\end{array}$ & $\begin{array}{l}\text { IR adoption } \\
\text { (dummy) }\end{array}$ & $\begin{array}{l}\text { Total per- } \\
\text { formance } \\
\text { measures } \\
\text { (Market } \\
\text { value of } \\
\text { equity) }\end{array}$ & + \\
\hline
\end{tabular}




\begin{tabular}{|c|c|c|c|c|c|c|}
\hline $\begin{array}{l}\text { Year of } \\
\text { publication }\end{array}$ & Author(s) & Sources & $\begin{array}{l}\text { State } \\
\text { Sample } \\
\text { Year(s) }\end{array}$ & $\begin{array}{l}\text { Independent } \\
\text { variable(s) }\end{array}$ & $\begin{array}{l}\text { Dependent } \\
\text { variable(s) }\end{array}$ & $\begin{array}{l}\text { Significant } \\
\text { results }\end{array}$ \\
\hline 2016 & Lee \& Yeo & $\begin{array}{l}\text { Review of } \\
\text { Quan- } \\
\text { titative } \\
\text { Finance \& } \\
\text { Account- } \\
\text { ing }\end{array}$ & $\begin{array}{l}\text { South } \\
\text { Africa } \\
822 \text { firm- } \\
\text { year } \\
\text { observa- } \\
\text { tions on } \\
\text { the JSE } \\
\text { 2010-2013 }\end{array}$ & $\begin{array}{l}\text { IR quality } \\
\text { (Standard } \\
\text { and Poor's } \\
\text { Global } \\
\text { Vantage; } \\
\text { score) } \\
\text { Moderators: } \\
\text { Organi- } \\
\text { zational } \\
\text { com- } \\
\text { plexity, } \\
\text { external } \\
\text { financing } \\
\text { needs }\end{array}$ & $\begin{array}{l}\text { Total per- } \\
\text { formance } \\
\text { measures } \\
\text { (Tobin's } \\
\text { Q) }\end{array}$ & $\begin{array}{l}+ \\
\text { Moderators: }+\end{array}$ \\
\hline
\end{tabular}

Funding Open Access funding enabled and organized by Projekt DEAL.

Open Access This article is licensed under a Creative Commons Attribution 4.0 International License, which permits use, sharing, adaptation, distribution and reproduction in any medium or format, as long as you give appropriate credit to the original author(s) and the source, provide a link to the Creative Commons licence, and indicate if changes were made. The images or other third party material in this article are included in the article's Creative Commons licence, unless indicated otherwise in a credit line to the material. If material is not included in the article's Creative Commons licence and your intended use is not permitted by statutory regulation or exceeds the permitted use, you will need to obtain permission directly from the copyright holder. To view a copy of this licence, visit http://creativecommons.org/licen ses/by/4.0/.

\section{References}

Adegboyegun, A. E., Alade, M. E., Ben-Caleb, E., Ademola, A. O., Eluyela, F. D., \& Oladipo, O. A. (2020). Integrated reporting and corporate performance in Nigeria: Evidence from the banking industry. Cogent Business and Management, 7, 1736866

Akisik, O., \& Gal, G. (2019). Integrated reports, external assurance and financial performance. An empirical analysis on North American firms. Sustainability Accounting, Management and Policy Journal, 11, 317-350

Albitar, K., \& Hussainey, K. (2020). ESG disclosure and firm performance before and after IR The moderating role of governance mechanisms. International Journal of Accounting and Information Management, 28, 429-444

Alfiero, S., Cane, M., Doronzo, R., \& Eposito, A. (2018). The effect of national cultural differences of board members on integrated reporting. Corporate Board, 14, 7-21

Baboukardos, D., \& Rimmel, G. (2016). Value relevance of accounting information under an integrated reporting approach: A research note. Journal of Accounting and Public Policy, 35, 437-452

Barth, M. E., Cahan, S. F., Chen, L., \& Venter, E. R. (2017). The economic consequences associated with integrated report quality: Capital market and real effects. Accounting, Organizations and Society, 62, 43-64

Ben-Amar, W., \& McIlkenny, P. (2015). Board effectiveness and the voluntary disclosure of climate change information. Business Strategy and the Environment, 24, 704-719 
Beretta, V., Demartini, C., \& Trucco, S. (2019). Does environmental, social and governance performance influence intellectual capital disclosure tone in integrated reporting? Journal of Intellectual Capital, 20, 100-124

Bernardi, C., \& Stark, A. W. (2018). Environmental, social and governance disclosure, integrated reporting, and the accuracy of analyst forecasts. The British Accounting Review, 50, 16-31

Caglio, A., Melloni, G., \& Perego, P. (2020). Informational content and assurance of textual disclosures: Evidence on integrated reporting. European Accounting Review, 29, 55-83

Camodeca, R., Almici, A., \& Sagliaschi, U. (2018). Sustainability disclosure in integrated reporting: Does it matter to investors? A Cheap Talk Approach. Sustainability, 10, 4393

Carroll, A. B., \& Shaban, K. M. (2010). The Business case for corporate social responsibility: A review of concepts, research and practice. International Journal of Management Reviews, 12, 85-105

Chouaibi, J., \& Hichri, A. (2020). Effect of the auditor's behavioural and individual characteristics on integrated reporting quality: Evidence from European companies. International Journal of Law and Management. https://doi.org/10.1108/IJLMA-04-2020-0109

Churet, C., \& Eccles, R. G. (2014). Integrated reporting, quality of management, and financial performance. Journal of Applied Corporate Finance, 26, 56-64

Conway, E. (2019). Quantitative impacts of mandatory integrated reporting. Journal of Financial Reporting and Accounting, 17, 604-634

Cortesi, A., \& Vena, L. (2019). Disclosure quality under integrated reporting: A value relevance approach. Journal of Cleaner Production, 220, 745-755

Cosma, S., Soana, M. G., \& Venurelli, A. (2018). Does the market reward integrated report quality? African Journal of Business Management, 12, 78-91

Davila, A., \& Venkatachalam, M. (2004). The relevance of non-financial performance measures for CEO compensation: Evidence from the airline industry. Review of Accounting Studies, 9, 443-464

de Villiers, C., Rinaldi, L., \& Unerman, J. (2014). Integrated reporting: Insights, gaps and an agenda for future research. Accounting, Auditing and Accountability Journal, 27, 1042-1067

de Villiers, C., Hsiao, K., \& Maroun, W. (2017a). Developing a conceptual model of influences around integrated reporting new insights and directions for future research. Meditari Accountancy Research, 25, 450-460

de Villiers, C., Venter, E. R., \& Hsiao, P. C. K. (2017b). Integrated reporting: Background, measurement issues, approaches and an agenda for future research. Accounting and Finance, 57, 937-959

Denyer, D., \& Tranfield, D. (2009). Producing a systematic review. In D. Buchanan \& A. Bryman (Eds.), The sage handbook of organizational research methods. (pp. 671-689). Sage.

Dey, P. K. (2020). Value relevance of integrated reporting: A study of the Bangladesh banking sector. International Journal of Disclosure and Governance. https://doi.org/10.1057/s41310-020-00084-Z

Dowling, J., \& Pfeffer, J. (1975). Organizational legitimacy: Social valued and organizational behavior. Pacific Sociological Review, 18, 122-136

Eccles, R. G., \& Krzus, M. P. (2015). The integrated reporting movement - meaning, momentum motives, and materiality. Wiley.

Eccles, R. G., \& Krzus, M. P. (2019). Implementing the task force on climate-related financial disclosures recommendations: An assessment of corporate readiness. Schmalenbach Business Review, $71,287-293$

Fasan, M., \& Mio, C. (2017). Fostering stakeholder engagement: The role of materiality disclosure in integrated reporting. Business Strategy and the Environment, 26, 288-307

Fernando, S., \& Lawrence, S. (2014). A theoretical framework for CSR practices: Integrating legitimacy theory, stakeholder theory and institutional theory. Journal of Theoretical Accounting Research, $10,149-178$

Flores, E., Fasan, M., Mendes-da-Silva, W., \& Oliveira-Sampaio, J. (2019). Integrated reporting and capital markets in an international setting: The role of financial analysts. Business Strategy and the Environment, 28, 1465-1480

Flower, J. (2015). The international integrated reporting council: A story of failure. Critical Perspectives on Accounting, 27, 1-17

Freeman, R. E. (1984). Strategic management: A stakeholder approach. Pitman.

Freeman, R. E., Harrison, J. S., Wicks, A. C., Parmar, B. L., \& de Colle, S. (2010). Stakeholder theory: The state of the art. Cambridge University Press.

Frias-Aceituno, J. V., Rodriguez-Ariza, L., \& Sanchez, I. M. (2013a). Is integrated reporting determined by a country's legal system? An exploratory study. Journal of Cleaner Production, 44, 45-55 
Frias-Aceituno, J. V., Rodriguez-Ariza, L., \& Garcia-Sanchez, I. M. (2013b). the role of the board in the dissemination of integrated corporate social reporting. Corporate Social Responsibility and Environmental Management, 20, 219-233

Frias-Aceituno, J. V., Rodriguez-Ariza, L., \& Garcia-Sanchez, I. M. (2014). Explanatory factors of integrated sustainability and financial reporting. Business Strategy and the Environment, 23, 56-72

Fuhrmann, S. (2019). A multi-theoretical approach on drivers on integrated reporting uniting firm-level and country-level associations. Meditari Accountancy Research, 28, 168-205

Fuhrmann, S., Ott, C., Looks, E., \& Guenther, T. W. (2017). The components of assurance statements for sustainability reports and information asymmetry. Accounting and Business Research, 47, 369-400

Gal, G., \& Akisik, O. (2020). The impact of internal control, external assurance, and integrated reports on market value. Corporate Social Responsibility and Environmental Management, 27, 1227-1240

Garcia-Sanchez, I. M., \& Noguera-Gamez, L. (2017a). Integrated reporting and stakeholder engagement. The effect on information asymmetry. Corporate Social Responsibility and Environmental Management, 24, 395-413

Garcia-Sanchez, I. M., \& Noguera-Gamez, L. (2017b). Integrated information and the cost of capital. International Business Review, 26, 959-975

Garcia-Sanchez, I. M., \& Noguera-Gamez, L. (2018). Institutional investor protection pressures versus firm incentives in the disclosure of integrated reporting. Australian Accounting Review, 28, 199-219

Garcia-Sánchez, I. M., Rodriguez-Ariza, L., \& Frias-Aceituno, J. V. (2013). The cultural system and integrated reporting. International Business Review, 22, 828-838

Garcia-Sanchez, I. M., Martinez-Ferrero, J., \& Garcia-Benau, M. A. (2019). Integrated reporting: The mediating role of the board of directors and investor protection on managerial discretion in munificent environments. Corporate Social Responsibility and Environmental Management, 26, 29-45

Garcia-Sánchez, I. M., Raimo, N., \& Vitolla, F. (2020). CEO power and integrated reporting. Meditari Accountancy Research. https://doi.org/10.1108/MEDAR-11-2019-0604

Gerwanski, J. (2020). Does it pay off? Integrated reporting and cost of debt: European evidence. Corporate Social Responsibility and Environmental Management. https://doi.org/10.1002/csr.1965

Gerwanski, J., Kordsachia, O., \& Velte, P. (2019). Determinants of materiality disclosure quality in integrated reporting: International evidence. Business Strategy and the Environment, 28, 750-770

Ghani, E. K., Jamal, J., Puspitasari, E., \& Gunardi, A. (2018). Factors Influencing integrated reporting practices among Malaysian public listed real property companies: A sustainable development effort. International Journal of Managerial and Financial Accounting, 10, 144-162

Gibbins, M., Richardson, A., \& Waterhouse, J. (1990). The management of corporate financial disclosure: Opportunism, ritualism, policies, and processes. Journal of Accounting Research, 28, 121-143

Girella, L., Rossi, P., \& Zambon, S. (2019). Exploring the firm and country determinants of the voluntary adoption of integrated reporting. Business Strategy and the Environment, 28, 1323-1340

Graßmann, M. (2020). The relationship between corporate social responsibility expenditures and firm value: The moderating role of integrated reporting. Journal of Cleaner Production. https://doi.org/ 10.1016/j.jclepro.2020.124840

Graßmann, M., Fuhrmann, S., \& Guenther, T. W. (2019). Drivers of the disclosed, connectivity of the capitals" evidence from integrated reports. Sustainability Accounting, Management and Policy Journal, 10, 877-908

Guerrero-Villegas, J., Pérez-Calero, L., Hurtado-González, J. M., \& Giráldez-Puig, P. (2018). Board attributes and corporate social responsibility disclosure: A meta-analysis. Sustainability, 10, 1-22

Haji, A. A., \& Anifowose, M. (2016). Audit committee and integrated reporting practice: Does internal assurance matter? Managerial Auditing Journal, 31, 915-948

Hasan, M., Roebuck, P., \& Simnett, R. (2003). An investigation of alternative report formats for communicating moderate levels of assurance. Auditing: A Journal of Practice and Theory, 22, 171-187

Helfaya, A., \& Moussa, T. (2017). Do board's corporate social responsibility strategy and orientation influence environmental sustainability disclosure? UK evidence. Business Strategy and the Environment, 26, 1061-1077

Huang, X. B., \& Watson, L. (2015). Corporate social responsibility research in accounting. Journal of Accounting Literature, 34, 1-16

IIRC. (2013). The International IR Framework, International Integrated Reporting Council. Retrieved April 3, 2020, http://www.theiircorg/wp-content/uploads/2013/12/13-12-08-THE-INTERNATIO NAL-IR-FRAMEWORK-2-1pdf. 
Jensen, J. C., \& Berg, N. (2012). Determinants of traditional sustainability reporting versus integrated reporting an institutionalist approach. Business Strategy and the Environment, 21, 299-316

Kannenberg, L., \& Schreck, P. (2019). Integrated reporting: Boon or bane? A review of empirical research on its determinants and implications. Journal of Business Economics, 89, 515-567

Kilic, M., \& Kuzey, C. (2018). Determinants of forward-looking disclosures in integrated reports. Managerial Auditing Journal, 33, 115-144

Kim, S., Shin, H., Shin, H., \& Park, S. (2019). Organizational slack, corporate social responsibility, sustainability, and integrated reporting: Evidence from Korea. Sustainability, 11, 4445

Klein, A. (2002). Audit committee, board of director characteristics, and earnings management. Journal of Accounting and Economics, 33, 375-400

Kolk, A., \& van Tulder, R. (2010). International business, corporate social responsibility and sustainable development. International Business Review, 19, 119-125

KPMG. (2017). The KPMG survey of corporate responsibility reporting. Retrieved April 3, 2020, from https://www.assetskpmgcom/content/dam/kpmg/xx/pdf/2017/10/kpmg-survey-of-corporate-respo nsibility-reporting-2017pdf.

Lai, A., Melloni, G., \& Stacchezzini, R. (2016). Corporate sustainable development: Is 'integrated reporting' a legitimation strategy? Business Strategy and the Environment, 25, 165-177

Landau, A., Rochell, J., Klein, C., \& Zwergel, B. (2020). Integrated reporting of environmental, social, and governance and financial data: Does the market value integrated reports? Business Strategy and the Environment, 29, 1750-1763

Lee, K. W., \& Yeo, G. H. H. (2016). The association between integrated reporting and firm valuation. Review of Quantitative Finance and Accounting, 47, 1221-1250

Lemma, T. T., Khan, A., Muttakin, M. B., \& Mihret, D. G. (2019). Is integrated reporting associated with corporate financing decisions? Some empirical evidence. Asian Review of Accounting, 27, $425-443$

Lewis, B. W., Walls, J. L., \& Dowell, G. W. S. (2014). Difference in degrees: CEO characteristics and firm environmental disclosure. Strategic Management Journal, 35, 712-722

Light, R. J., \& Smith, P. V. (1971). Accumulating evidence: Procedures for resolving contradictions among different research studies. Harvard Educational Review, 41, 429-471

Loprevite, S., Ricca, B., \& Rupo, D. (2018). Performance sustainability and integrated reporting: Empirical evidence from mandatory and voluntary adoption contexts. Sustainability, 10, 1351

Loprevite, S., Rupo, D., \& Ricca, B. (2019a). Does the voluntary adoption of integrated reporting affect the value relevance of accounting information? Empirical evidence from Europe. International Journal of Managerial and Financial Accounting, 11, 238-268

Loprevite, S., Rupo, D., \& Ricca, B. (2019b). Integrated reporting practices in Europe and value relevance of accounting information under the framework of IIRC. International Journal of Business and Management, 13, 1-12

Maassen, G., \& van den Bosch, F. (1999). On the supposed independence of two-tier boards: Formal structure and reality in the Netherlands. Corporate Governance: an International Review, 7, 31-37

Mahoney, L. S., Thorne, L., Cecil, L., \& LaGore, W. (2013). A research note on standalone corporate social responsibility reports: Signaling or greenwashing? Critical Perspectives on Accounting, 24, 350-359

Maniora, J. (2017). Is integrated reporting really the superior mechanism for the integration of ethics into the core business model? An empirical analysis. Journal of Business Ethics, 140, 755-786

Maroun, W. (2017). Assuring the integrated report: Insights and recommendations from auditors and preparers. The British Accounting Review, 49, 329-346

Maroun, W. (2019). Does external assurance contribute to higher quality integrated reports? Journal of Accounting and Public Policy, 38, 106670

Marrone, A. (2020). Corporate governance variables and integrated reporting. International Journal of Business and Management, 15, 26-36

McGuinness, P. B., Vieito, J. P., \& Wang, M. (2017). The role of board gender and foreign ownership in the CSR performance of Chinese listed firms. Journal of Corporate Finance, 42, 75-99

Melloni, G., Caglio, A., \& Perego, P. (2017). Saying more with less? Disclosure conciseness, completeness and balance in integrated reports. Journal of Accounting and Public Policy, 36, 220-238

Mervelskemper, L., \& Streit, D. (2017). Enhancing market valuation of ESG performance: Is integrated reporting keeping its promise? Business Strategy and the Environment, 26, 536-549

Moloi, T., \& Iredele, O. (2020). Firm value and integrated reporting quality of South African listed firms. Academy of Strategic Management Journal, 19, 1-12 
Muttakin, M. B., Mihret, D. G., Lemma, T., \& Khan, A. (2020). Integrated reporting, financial reporting quality and cost of debt. International Journal of Accounting and Information Management, $28,517-534$

Obeng, V. A., Ahmed, K., \& Migliani, S. (2020a). Integrated reporting and earnings quality: The moderating effect of agency costs. Pacific-Basin Finance Journal, 60, 101285

Obeng, V. A., Ahmed, K., \& Cahan, S. F. (2020b). Integrated reporting and agency costs: International evidence from voluntary adopters. European Accounting Review. https://doi.org/10.1080/ 09638180.2020 .1805342

O'Connell, V., \& O'Sullivan, D. (2014). The influence of lead indicator strength on the use of nonfinancial measures in performance management: Evidence from CEO compensation schemes. Strategic Management Journal, 35, 826-844

Omran, M. S. Y., Zaid, A. A., \& Dwekat, A. (2020). The relationship between integrated reporting and corporate environmental performance: A green trial. Corporate Social Responsibility and Environmental Management. https://doi.org/10.1002/csr.2059

Oshika, T., \& Saka, C. (2017). Sustainability KPIs for integrated reporting. Social Responsibility Journal, 13, 625-642

Pavlopoulos, A., Magnis, C., \& Iatridis, G. E. (2017). Integrated reporting: Is it the last piece of the accounting disclosure puzzle? Journal of Multinational Financial Management, 41, 23-46

Pavlopoulos, A., Magnis, C., \& Iatridis, G. E. (2019). Integrated reporting: An accounting disclosure tool for high quality financial reporting. Research in International Business and Finance, 49, $13-40$

Renneboog, L., ter Horst, J., \& Zhang, C. (2008). Socially responsible investments: Institutional aspects, performance, and investor behavior. Journal of Banking and Finance, 32, 1723-1742

Raimo, N., Vitolla, F., Marrone, A., \& Rubino, M. (2020a). Do audit committee attributes influence integrated reporting quality? An agency theory viewpoint. Business Strategy and the Environment, 30, 522-534

Raimo, N., Vitolla, F., Marrone, A., \& Rubino, M. (2020b). The role of ownership structure in integrated reporting policies. Business Strategy and the Environment. https://doi.org/10.1002/bse. 2498

Rivera-Arrubla, Y. A., Zorio-Grima, A., \& Garcia-Benau, M. A. (2017). Integrated reports: Disclosure level and explanatory factors. Social Responsibility Journal, 13, 155-176

Roychowdhury, S. (2006). Earnings management through real activities manipulation. Journal of Accounting and Economics, 42, 335-370

Roman, A. G., Mocanu, M., \& Hoinaru, R. (2019). Disclosure style and its determinants in integrated reports. Sustainability, 11,1960

Romero, S., Ruiz, S., \& Fernandez-Feijoo, B. (2019). Sustainability reporting and stakeholder engagement in Spain: Different instruments, different quality. Business Strategy and the Environment, $28,221-232$

Rupley, K. H., Brown, D., \& Marshall, R. S. (2012). Governance, media and the quality of environmental disclosure. Journal of Accounting and Public Policy, 31, 610-640

Schaltegger, S., Hörisch, J., \& Freeman, R. E. (2019). Business cases for sustainability: A stakeholder theory perspective. Organization \& Environment, 32, 191-212

Serafeim, G. (2015). Integrated reporting and investor clientele. Journal of Applied Corporate Finance, 27, 34-51

Seuring, S., \& Mueller, M. (2008). Core issues in sustainable supply chain management-a Delphi study. Business Strategy and the Environment, 17, 455-466

Shocker, A. D., \& Sehti, S. P. (1973). An approach to incorporating societal preferences in developing corporate action strategies. California Management Review, 15, 97-105

Sierra-Garcia, L., Zorio-Grima, A., \& Garcia-Benau, M. A. (2015). Stakeholder engagement, corporate social responsibility and integrated reporting: An exploratory study. Corporate Social Responsibility and Environmental Management, 22, 286-304

Simnett, R., \& Huggins, A. L. (2015). Integrated reporting and assurance: Where can research add value? Sustainability Accounting, Management and Policy Journal, 6, 29-53

Sriani, D., \& Agustia, D. (2020). Does voluntary integrated reporting reduce information asymmetry? Heliyon, 6, e05602

Stacchezzini, R., Melloni, G., \& Lai, A. (2016). Sustainability management and reporting: The role of integrated reporting for communicating corporate sustainability management. Journal of Cleaner Production, 136(Part A), 102-110 
Tlili, M., Othman, H. B., \& Hussainey, K. (2019). Does integrated reporting enhance the value relevance of organizational capital? Evidence from the South African context. Journal of Intellectual Capital, 20, 642-661

Torraco, R. J. (2005). Writing integrative literature reviews: Guidelines and examples. Human Resource Development Review, 4, 356-367

Vaz, N., Fernandez-Feijoo, B., \& Ruiz, S. (2016). Integrated reporting: An international overview. Business Ethics: A European Review, 25, 577-591

Velte, P. (2018). Is audit committee expertise connected with increased readability of integrated reports? Evidence from EU companies. Problems and Perspectives in Management, 16, 23-41

Velte, P., \& Stawinoga, M. (2017a). Integrated reporting: The current state of empirical research, limitations and future research implications. Journal of Management Control, 28, 275-320

Velte, P., \& Stawinoga, M. (2017b). Empirical research on corporate social responsibility assurance (CSRA): A literature review. Journal of Business Economics, 87, 1017-1066

Velte, P., \& Stawinoga, M. (2020). Do chief sustainability officers and CSR committees influence CSR-related outcomes? A structured literature review on empirical-quantitative research findings. Journal of Management Control. https://doi.org/10.1007/s00187-020-00308-X

Velte, P., Stawinoga, M., \& Lueg, R. (2020). Carbon performance and disclosure: A systematic review of governance-related determinants and financial consequences. Journal of Cleaner Production, 254,120063

Vena, L., Sciascia, S., \& Cortesi, A. (2020). Integrated reporting and cost of capital. The moderating role of cultural dimensions. Journal of International Financial Management and Accounting, $31,191-214$

Vitolla, F., Raimo, N., \& Rubino, M. (2019a). Appreciations, criticisms, determinants, and effects of integrated reporting: A systematic literature review. Corporate Social Responsibility and Environmental Management, 261, 518-528

Vitolla, F., Raimo, N., Rubino, M., \& Garzoni, A. (2019b). How pressure from stakeholders affect integrated reporting quality. Corporate Social Responsibility and Environmental Management, 26, 1591-1606

Vitolla, F., Raimo, N., Rubino, M., \& Garzoni, A. (2019c). The impact of national culture on integrated reporting quality: A stakeholder theory approach. Business Strategy and the Environment, 28, 1558-1571

Vitolla, F., Raimo, N., \& Rubino, M. (2020a). Board characteristics and integrated reporting quality: An agency theory perspective. Corporate Social Responsibility and Environmental Management, 27, 1152-1163

Vitolla, F., Salvi, A., Raimo, N., Petruzzella, F., \& Rubino, M. (2020b). The impact on the cost of equity in the effects of integrated reporting quality. Business Strategy and the Environment, 29, 519-529

Vitolla, F., Raimo, N., Rubino, M., \& Garzoni, A. (2020c). The determinants of integrated reporting quality in financial institutions. Corporate Governance, 20, 429-444

Vitolla, F., Raimo, N., Marrone, A., \& Rubino, M. (2020d). The role of board of directors in intellectual capital disclosure after the advent of integrated reporting. Corporate Social Responsibility and Environmental Management. https://doi.org/10.1002/csr.1957

Wachira, M. M., Berndt, T., \& Romero, C. M. (2019). The adoption of international sustainability and integrated reporting guidelines within a mandatory reporting framework: Lessons from South Africa. Social Responsibility Journal, 16, 613-629

Wahl, A., Charifzadeh, M., \& Diefenbach, F. (2020). Voluntary adopters of integrated reporting. evidence on forecast accuracy and firm value. Business Strategy and the Environment, 29, 2542-2556

Wang, R., Zhou, S., \& Wang, T. (2020). Corporate governance, integrated reporting and the use of credibility-enhancing mechanisms on integrated reports. European Accounting Review, 29, 631-663

Wanner, J., \& Janiesch, C. (2019). Big data analytics in sustainability reports: An analysis based on the perceived credibility of corporate published information. Business Research, 12, 143-173

Webster, J., \& Watson, R. T. (2002). Analyzing the past to prepare for the future: Writing a literature review. MIS Quarterly, 26, XIII-XXIII

Winschel, J., \& Stawinoga, M. (2019). Determinants and effects of sustainable CEO compensation: a structured literature review of empirical evidence. Management Review Quarterly, 69, 265-328 
Wintoki, M. B., Linck, J. S., \& Netter, J. M. (2012). Endogeneity and the dynamics of internal corporate governance. Journal of Financial Economics, 105, 581-606

Zhou, S., Simnett, R., \& Green, W. (2017). Does integrated reporting matter to the capital market? Abacus, 53, 94-132

Zuniga, F., Pincheira, R., Walker, J., \& Turner, M. (2020). The effect of integrated reporting quality on market liquidity and analyst forecast error. Accounting Research Journal, 33, 635-650

Publisher's Note Springer Nature remains neutral with regard to jurisdictional claims in published maps and institutional affiliations.

\section{Authors and Affiliations}

\section{Patrick Velte ${ }^{1}$ (ID)}

1 Institute of Management, Accounting \& Finance (IMAF), Leuphana University of Lüneburg, Universitaetsallee 1, 21335 Lüneburg, Germany 